LOS DERECHOS DE LA MUJER CABEZA DE FAMILIA Y EL REGIMEN JURIDICO DE LA PROVISIONALIDAD EN COLOMBIA

RUTH YAMILÉ VARGAS REYES

MAESTRÍA DERECHO PÚBLICO

UNIVERSIDAD SANTO TOMÁS

LOS DERECHOS DE LA MUJER CABEZA DE FAMILIA Y LA MERITOCRACIA EN 


\title{
COLOMBIA
}

Tesis para aspirar al título de Magíster en Derecho Público

RUTH YAMILÉ VARGAS REYES

Candidata a Magíster

Director

DR. ANDRÉS ABEL RODRÍGUEZ VILLABONA

\author{
MAESTRÍA EN DERECHO PÚBLICO \\ UNIVERSIDAD SANTO TOMÁS \\ BOGOTÁ 2017
}

\section{Tabla de contenido}

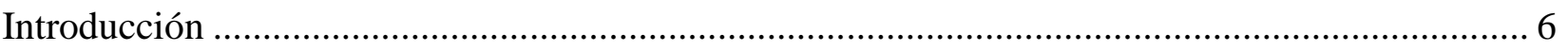

Parte I. La meritocracia frente a la provisionalidad .......................................................... 13

Capítulo 1. La Meritocracia en Colombia ......................................................................... 13

Principales momentos de la evolución de la meritocracia en Colombia ............................. 15

Carrera administrativa en el Estado Social de Derecho................................................... 19

Proceso de selección en la carrera administrativa........................................................ 23 
Fundamentos jurídicos de la provisionalidad .......................................................... 29

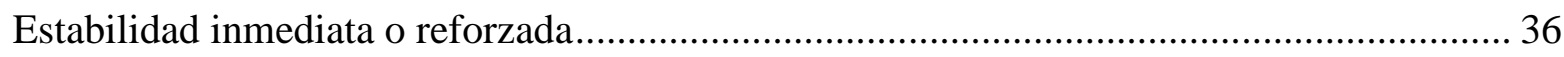

Actos administrativos que declaran la insubsistencia ................................................. 40

Posiciones del Consejo de Estado y la Corte Constitucional frente a la provisionalidad ..... 45

Balance del enfrentamiento judicial ........................................................................ 54

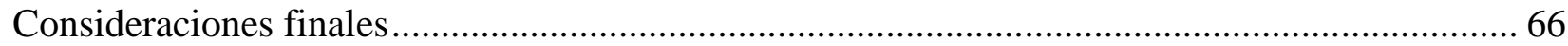

Parte II. Vinculación excepcional al estado de la mujer cabeza de familia ............................... 74

Capítulo 3. La mujer cabeza de familia en Colombia ............................................................ 74

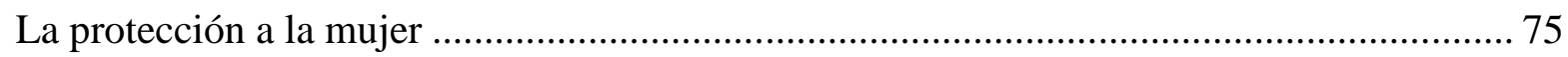

Estudio constitucional, legal y jurisprudencial respecto de los derechos de las mujeres

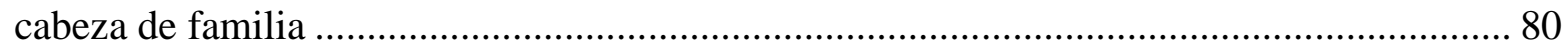

La protección especial que el Estado debe brindar a las mujeres cabeza de familia ............ 95

Vulneración de derechos fundamentales y económicos de la mujer cabeza de familia con la declaratoria de su insubsistencia ........................................................................... 109

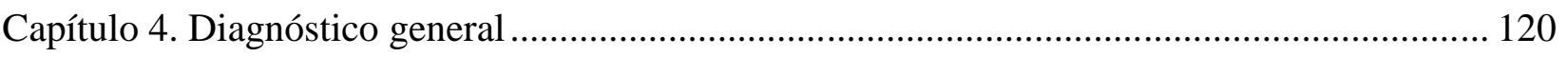

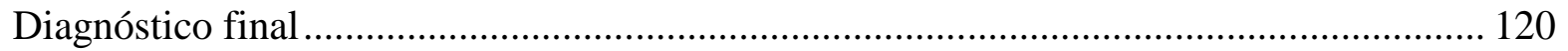

Consecuencias legales y sociales de la declaratoria de insubsistencia de las mujeres cabeza de familia que se encuentran vinculadas al Estado en provisionalidad ............................ 126

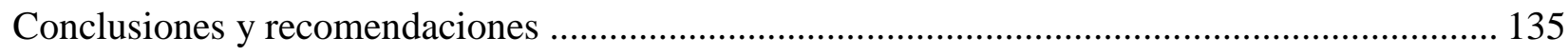

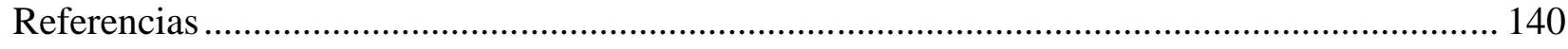

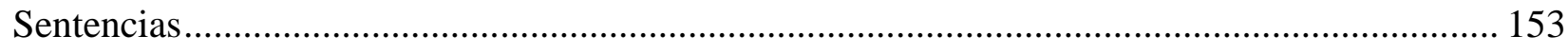




\section{Introducción}

El régimen jurídico colombiano estableció la figura de la provisionalidad como un recurso excepcional para proveer cargos públicos. Sin embargo, dejó de ser una excepción y se convirtió en la manera

como se han vinculado muchos servidores, lo cual evidentemente tiene importantes repercusiones a nivel personal, pero también para la eficiente gestión de administración e incluso para la legitimidad de las autoridades. Esta situación se agrava cuando el servidor se haya en contextos de especial vulnerabilidad, como es el caso de las mujeres cabeza de familia, hombres cabeza de familia que se encuentran en dicha situación. Todo ello justifica desarrollar un estudio que permita formular propuestas que puedan hacer frente a esta problemática el cual se ha delimitado a este grupo de personas, teniendo en cuenta además que ha dado lugar a profundas discusiones, que se evidencian, por ejemplo, en las diferentes y encontradas posiciones de la Corte Constitucional y el Consejo de Estado. Así mismo, algunas iniciativas legislativas se han presentado para buscar una solución definitiva, a través de la vinculación automática de las personas que se encuentran en la modalidad excepcional; con todo, las propuestas no fueron acogidas por las altas Cortes, en tanto que se configuraría una estabilidad forzada que no estaría jurídicamente justificada.

Como se puede observar, la situación no es fácil, debido a que, por un lado, se encuentra la obligación del Estado de garantizar la provisión de los cargos públicos a través de concurso de méritos y, por el otro, se halla la garantía de los derechos fundamentales de las mujeres y hombres cabeza de familia que han ocupado cargos públicos por varios años bajo dicha modalidad, siendo en principio responsable de esta situación el mismo Estado, pues no ha surtido los concursos de 
méritos de manera general, más aun cuando el 16 de enero fue expedido el Decreto 051 de 2018, mediante el cual se reiteró que es deber de las entidades de orden nacional apropiar el monto de los recursos y las entidades de orden territorial priorizar el gasto con el fin de adelantar los concursos de méritos abiertos, es decir que en cualquier momento ha de decidirse acerca de la situación de las mujeres (madres) y hombres (padres) cabeza de familia por ende de su núcleo familiar que se encuentran vinculadas bajo la modalidad excepcional, en donde en principio se resolvería declarando su insubsistencia en el momento en que se surta el concurso de méritos, sin embargo, también se debe pensar en los otros derechos que los cobijan y que no tienen menor importancia que la exigencia constitucional del concurso de méritos.

La Constitución Política de Colombia de $1991^{1}$ les otorgó una protección especial a las mujeres, en dicha situación al incorporarlas a ciertos grupos que se encuentran en desventaja frente a la sociedad, protección que en ejercicio del derecho a la igualdad se extiende a hombres cabeza de familia o aquellas personas que sin tener vínculos de sangre tienen el cuidado de personas a cargo ya sea por un vínculo legal, decisión judicial o administrativa o que carecen de formalidad, sin embargo el trabajo se delimitará a la situación de mujeres y hombres cabeza de familia dado que según la encuesta ELCA (Encuesta longitudinal que sigue cada tres años a aproximadamente 10.000 hogares colombianos en zonas rurales y urbanas de Colombia ) de la universidad de los Andes, el número de mujeres cabeza de familia en Colombia ha venido en aumento, el incremento ha sido de cuatro puntos porcentuales en los últimos cinco años en ambas poblaciones, que las mujeres cabeza de hogar en ciudades pasaron del 35 al 39 por ciento, entre el 2010 y el 2016.

También el DANE estableció que actualmente hay 22 millones de mujeres de las cuales el 56\% son cabeza de familia y también según estudios de la organización Internacional de Trabajo, el Banco Mundial y la Cepal revelan que la jornada de trabajo de las mujeres en labores remuneradas 
y no remuneradas es mayor que la de los hombres, que la distribución de las tareas domesticas sigue siendo desigual debido a que el tiempo remunerado de ellas se ve recargado de atender el cuidado de los hijos pequeños, enfermos o adultos mayores. Es por esa razón que el trabajo de investigación se direcciona a este grupo importante de mujeres en tanto que la condición de desigualdad ha sido evidenciada y es por ello que las constituciones en este caso la colombiana ordenan una protección especial hacia las mismas.

En efecto, los intentos legislativos con los cuales se pretendía dar una solución definitiva a la situación han sido fallidos, en tanto que la Corte Constitucional los ha declarado inexequibles por contravenir el artículo 125 de la Carta Política de $1991^{2}$ y el derecho a la igualdad. Con todo, el ente competente para realizar los concursos de méritos, la Comisión Nacional de Servicios Civil, no los ha adelantado; dando lugar a que la provisión de los cargos se realice a través de la excepción, inicialmente por un término de seis meses que se ha ido prolongado indefinidamente.

En este contexto, el trabajo de investigación que a continuación se presenta requiere de un estudio del sistema de la meritocracia en Colombia, para culminar con el tema de los nombramientos en provisionalidad, su injerencia en la administración pública y la obligación que tiene el Estado a través del concurso de méritos de garantizar el cumplimiento de sus fines esenciales. A partir de esto, se analiza en concreto la situación de una parte de la población que según la Constitución Política

${ }^{1}$ Artículo 43 de la Constitución Política de Colombia de 1991:

La mujer y el hombre tienen iguales derechos y oportunidades. La mujer no podrá ser sometida a ninguna clase de discriminación. Durante el embarazo y después del parto gozará de especial asistencia y protección del Estado, y recibirá de éste subsidio alimentario si entonces estuviere desempleada o desamparada. El 
Estado apoyará de manera especial a la mujer cabeza de familia. (Art. 43) ${ }^{2}$ Artículo

125 de la Constitución Política de Colombia de 1991:

Los empleos en los órganos y entidades del Estado son de carrera. Se exceptúan los de elección popular, los de libre nombramiento y remoción, los de trabajadores oficiales y los demás que determine la ley. Los funcionarios, cuyo sistema de nombramiento no haya sido determinado por la Constitución o la ley, serán nombrados por concurso público. El ingreso a los cargos de carrera y el ascenso en los mismos, se harán previo cumplimiento de los requisitos y condiciones que fije la ley para determinar los méritos y calidades de los aspirantes. El retiro se hará: por calificación no satisfactoria en el desempeño del empleo; por violación del régimen disciplinario y por las demás causales previstas en la Constitución o la ley. En ningún caso la filiación política de los ciudadanos podrá determinar su nombramiento para un empleo de carrera, su ascenso o remoción. Los períodos establecidos en la Constitución Política o en la ley para cargos de elección tienen el carácter de institucionales. Quienes sean designados o elegidos para ocupar tales cargos, en reemplazo por falta absoluta de su titular, lo harán por cl resto del período para el cual este fue elegido. (Art. 125)

de Colombia de 1991 en su artículo $43^{1}$ goza de protección especial del Estado, esto es, las

mujeres cabeza de familia que se encuentran vinculadas a cargos públicos bajo la modalidad excepcional de la provisionalidad y que en ejercicio del derecho a la igualdad se extiende a los hombres cabeza de familia o aquellas personas que sin tener vínculos de sangre tienen el cuidado de personas a cargo ya sea por un vínculo legal, decisión judicial o administrativa o que carecen de formalidad, sin embargo el trabajo se delimitará a la situación de mujeres y hombres cabeza de familia.

Es así como el trabajo de investigación no se orienta a erradicar del ordenamiento jurídico la provisionalidad como forma de vinculación excepcional al Estado, sino que el problema que se pretende abordar es el de saber si al declararse la insubsistencia de una mujer u hombre cabeza de familia a raíz de un concurso de méritos para proveer un cargo de carrera administrativa al cual se encontraba vinculada en provisionalidad, se produce o no una afectación injustificada de sus

\footnotetext{
${ }^{1}$ Artículo 43:
}

La mujer y el hombre tienen iguales derechos y oportunidades. La mujer no podrá ser sometida a ninguna clase de discriminación. Durante el embarazo y después del parto gozará de especial asistencia y protección del Estado, y recibirá de éste subsidio alimentario si entonces estuviere desempleada o desamparada. El Estado apoyará de manera especial a la mujer cabeza de familia. (Constitución Política de Colombia, 1991, Art. 43) 
derechos fundamentales, así como los de su núcleo familiar. Verificada dicha afectación en este caso, es necesario igualmente definir si es posible adelantar un proceso especial que permita la inscripción automática de los servidores (mujer y hombre cabeza de familia) desvinculados u otras medidas especiales de protección. Por consiguiente, la pregunta central de investigación se puede plantear en estos términos: ¿Se produce una afectación constitucionalmente inadmisible de los derechos fundamentales de las mujeres y hombres cabeza de familia que ocupan un cargo público en provisionalidad cuando son declarados insubsistentes como consecuencia de un concurso de méritos realizado en cumplimiento del principio constitucional de meritocracia?

El objetivo principal de esta investigación se evidencia en la manera como se acaba de plantear el problema. En efecto, se pretende analizar desde el punto de vista jurídico las obligaciones por parte del Estado frente a los derechos de las mujeres y hombres cabeza de familia que ocupan cargos públicos en provisionalidad, en el caso de que su vinculación se vea afectada por un concurso de méritos en desarrollo de lo previsto en la Constitución y actualmente por el decreto 051 de 2018 proferido por el Presidente de la República en enero de esta anualidad en donde se decretò a las entidades de orden nacional apropiar el monto de los recursos y las entidades de orden territorial priorizar recursos con el fin de adelantar los concursos abiertos de méritos.

Para lograr este objetivo, se pretende, en especial, analizar el sistema de méritos en Colombia y su evolución en el ordenamiento jurídico y en la jurisprudencia nacional, así como la figura excepcional de la provisionalidad como forma de vinculación al Estado y su estatus en nuestro ordenamiento jurídico y en la jurisprudencia nacional. Igualmente, se busca definir los mecanismos de protección especial que el Estado debe brindar a la mujer y hombre cabeza de familia -también 
desde la perspectiva legal y jurisprudencial- y realizar un diagnóstico general, con referencia a algunos casos puntuales de ciertas entidades estatales en donde se encuentran vinculados en provisionalidad madres y hombres cabeza de familia. Todo ello permitirá determinar las consecuencias legales, e incluso algunas de carácter social, que terminarían soportando las madres y padres cabeza de familia en el evento de ser declarados insubsistentes, y las eventuales consecuencias patrimoniales para el Estado en el evento de ser reintegrados en sus cargos luego de entablar las correspondientes acciones legales.

Para lograr el objetivo de investigación el trabajo se divide en dos partes: una primera parte, que se subdivide en dos capítulos, analiza la meritocracia en Colombia, así como el origen y la evolución de la figura de la provisionalidad como modalidad de vinculación al Estado. La segunda parte, que también contiene dos capítulos, aborda el concepto de familia que trajo consigo la Constitución Política de Colombia de 1991 en su artículo $42^{2}$ y el concepto de la mujer cabeza de familia, dispuesto en el artículo 2 de la Ley 82 de $1993^{3}$, para de esta forma ocuparse de la protección especial que el Estado debe a la mujer en esta situación en el marco de su vinculación al mismo bajo la modalidad excepcional, todo ello en ejercicio del derecho a la igualdad el cual permite que la protección especial se extienda a hombres cabeza de familia.

Así pues, se pretende determinar el alcance de la vulneración de sus derechos fundamentales y económicos, así como los de su núcleo familiar, cuando son declarados insubsistentes, estudio que girará principalmente en torno al régimen constitucional, legal y jurisprudencial. Finalmente, se

\footnotetext{
${ }^{2}$ Artículo 42: “[...] constituye por vínculos naturales o jurídicos, por la decisión libre de un hombre y una mujer de contraer matrimonio o por la voluntad responsable de conformarla" (Constitución Política de Colombia, 1991, Art. 42). Es decir que la familia puede conformarse por el matrimonio, la unión marital de hecho o la adopción.

${ }^{3}$ Artículo 2 de la Ley 82 de 1993 "Por la cual se expiden normas para apoyar de manera especial a la mujer cabeza de familia, modificado por el artículo $1^{\circ}$ de la Ley 1232 de 2008, establece que “[...] es Mujer Cabeza de familia, quien [...] ejerce la jefatura del hogar y tiene bajo su cargo, afectiva, económica o socialmente, en forma permanente, hijos menores propios u otras personas incapaces o incapacitadas para trabajar [...]" (Ley 82, 1993, Art. 2).
} 
presentarán conclusiones de la investigación y se plantearán algunas propuestas y recomendaciones para responder al problema jurídico. La investigación que sustenta este tesis de maestría se realizó con fundamento en el análisis de la normatividad constitucional y legal que regula el tema del que se ocupa, la jurisprudencia del Consejo de Estado y la Corte Constitucional, los aportes de la doctrina (en artículos y libros), además de otros trabajos de grado en los cuales se ha realizado el correspondiente análisis de la problemática. Asimismo, se tuvo en cuenta la situación especial de las entidades en donde la provisionalidad es una de las modalidades más extendidas de vinculación a los cargos públicos. Estos presupuestos metodológicos parten del hecho que la investigación jurídica tiene como finalidad el estudio del Derecho, y para ello es necesario recurrir a las fuentes de investigación jurídicas que, a su vez, son aquellos elementos que permiten desarrollar un tema en concreto. Dichas fuentes principales según Ayestaran (2011) son las siguientes:

(1) La ley, que representa la fuente jurídica formal por excelencia, y en ocasiones suele ser tomada como fuente única y exclusiva de la investigación jurídica; (2) la jurisprudencia, que es una fuente importante pues representa o muestra el criterio constante de los órganos jurisdiccionales (contrario a lo que cada vez en menor grado se creía, en el sentido de que la jurisprudencia es un criterio aislado y a veces único que emana de ciertas decisiones); (3) la doctrina, que es una fuente de consulta inevitable, debido a que comprende la opinión de personas calificadas que siempre, de una manera u otra, influyen sobre el estado actual o futuro del Derecho; (4) la realidad social, [...] que es la fuente más importante, no obstante ser la más compleja, porque su análisis implica un alto grado de abstracción presente y requiere que el investigador tenga una alta capacidad para separar y unir hechos, en la medida en que el objeto de análisis es el presente y los hechos que pueden dar lugar a futuros sistemas jurídicos o instituciones jurídicas. (párr. 4) 


\section{Parte I. La meritocracia frente a la provisionalidad}

En esta primera parte de la investigación es necesario ocuparse del sistema de meritocracia frente a la figura de la provisionalidad en Colombia de esta manera se concretará el objeto de la presente investigación como es el análisis y condición de las madres y padres cabeza de familia vinculados en provisionalidad al Estado. Para ello se desarrolla en dos capítulos, en el primero de los cuales se estudia el sistema de meritocracia en Colombia, considerando en particular el concepto de función pública, la evolución del concurso de méritos, la carrera administrativa en el marco del Estado Social de Derecho y el proceso de selección en el sistema de méritos. En el segundo capítulo se analiza la figura de la provisionalidad en Colombia, su evolución como forma de vinculación al Estado, la estabilidad reforzada, los actos administrativos que declaran la insubsistencia de las personas que fueron vinculadas bajo la modalidad excepcional, para finalizar con un breve resumen de las diferentes posiciones del Consejo de Estado y de la Corte Constitucional, en los casos donde se ha tratado la figura de la provisionalidad.

\section{Capítulo 1. La Meritocracia en Colombia}

Para abordar el sistema de méritos en Colombia es necesario en primera instancia definir la función pública a la luz del ordenamiento jurídico. Esta se entiende como aquel conjunto de relaciones laborales entre el Estado y sus servidores que desempeñan las funciones contempladas en la Constitución Política, en la Ley o un Reglamento, es decir que es aquella actividad realizada 
en cabeza de personas naturales en nombre del Estado cuyo objetivo es el cumplimiento de los fines esenciales del mismo (Sentencia del 23 de febrero, 2006).

Bergeron Gerard define la función pública como una serie de actividades relacionadas entre sí en el proceso de acción, que se encuentran unidas para un fin común que es la vida del organismo. Asì mismo, Raymond Carre de Malber indica que en la función pública las funciones son los objetivos y metas, propone además las diferencias del Estado en Constituyente, administrativa, legislativa, judicial de control fiscal, de Ministerio electoral, de planeación, de defensa y de seguridad (ambos autores citados en Bohórquez, 2012).

Según Olano (2016) la función pública se define:

[Como] el conjunto de regímenes aplicables a todos los organismos y entidades de la Rama Ejecutiva del Poder Público y la Administración Pública y a los servidores públicos que por mandato constitucional o legal tengan a su cargo la titularidad y el ejercicio de funciones administrativas, prestación de servicios públicos o provisión de obras y bienes públicos $\mathrm{y}$, en lo pertinente, a los particulares cuando cumplan funciones administrativas. (p. 15)

Por otro lado, la Corte Constitucional se ha pronunciado en varias ocasiones respecto de la función pública y los principios que deben regir en esta. Entre dichos pronunciamientos se encuentra la Sentencia C-563 de 1998, en donde indicó que la función pública es el conjunto de las actividades que realiza el Estado, a través de los órganos de las ramas del poder público de los órganos autónomos e independientes y demás entidades y agencias públicas para alcanzar sus diferentes fines, y que en sentido restringido se habla del conjunto de principios y reglas que se aplican a quienes tienen vínculo laboral subordinado con los diferentes organismos del Estado. 
A partir de esta aproximación conceptual, y antes de profundizar en el estudio del régimen jurídico de la meritocrácia en Colombia para terminar con el estudio de la provisionalidad y analizar la situación de las madres y padres cabeza de familia que se encuentran vinculadas bajo la modalidad excepcional, conviene presentar algunos elementos centrales de su evolución histórica, por lo menos desde finales del siglo XIX. A continuación se hará también mención a las especificidades de la carrera administrativa en el marco del Estado Social de Derecho en nuestro país, para finalizar con un estudio más puntual sobre el proceso de selección en el marco de la carrera administrativa.

\section{Principales momentos de la evolución de la meritocracia en Colombia}

Mientras que después del proceso de independencia y durante casi todo el siglo XIX no existieron criterios meritocráticos para el nombramiento de los servidores públicos, con la expedición de la Constitución de 1886 se establecieron los primeros intentos de introducir este tipo de modelo. En efecto, como lo indica Martínez (2010):

La Constitución de $1886^{4}$ limitó la atribución nominadora del presidente de la República, de los gobernadores y de los alcaldes, ya que conforme a ella, el libre nombramiento y remoción sólo podía hacerse 'de acuerdo con las normas que expida el Congreso para establecer y regular las condiciones del acceso al servicio público, de ascensos por méritos y antigüedad, de jubilación, retiro o despidos’. (p. 111)

Posteriormente, en 1902, durante el gobierno de José Manuel Marroquín, el General Uribe Uribe, a través de la Comisión Delegada para la Reforma del Estado presentó ante el Congreso el

\footnotetext{
${ }^{4}$ Constitución Política de 1886: Artículo 62:
} 
primer anteproyecto de la carrea administrativa (Puentes, 2004 como se citó en Martínez, 2010), exponiendo los correspondientes motivos $^{7}$ que movieron el primer intento de implementar la carrera administrativa en Colombia para proveer los cargos públicos de las diferentes entidades que conforman la estructura del Estado.

En 1936 se produjo la reforma política, modificándose el artículo 64 de la Constitución de $1886^{8}$ con la finalidad de evitar que los dineros públicos del tesoro quedaran bajo el arbitrio de una misma persona. Sin embargo, fue en el gobierno de Eduardo Santos en el que se expidió la

La ley determinará los casos particulares de incompatibilidad de funciones; los de responsabilidad de los funcionarios y modo de hacerla efectiva; las calidades y antecedentes necesarios para el desempeño de ciertos empleos, en los casos no previstos por la Constitución; las condiciones de ascenso y de jubilación; y la serie o clase de servicios civiles o militares que dan derecho a pensión del Tesoro público. (Constitución Política, 1886, Art. 62)

${ }^{7}$ La elección de los empleados, sea hecha por quien fuere y por el sistema que fuere, debe recaer en aquellos ciudadanos que tengan competencia para su puesto, es decir, carácter, habilidad técnica, experiencia, honradez, posición social, y buenos antecedentes, que los coloque en posibilidad de servir mejor que cualquier otro, el cargo que se trate. El gobierno que rehúse o arrebate el empleo a un ciudadano dotado de esas prendas y lo entregue a otro que carezca de ellas siempre será — llámese como se llamare — un detestable gobierno, porque de cualquier cosa podrá jactarse, menos de administrar rectamente los intereses del pueblo; y porque contraponer intereses especiales a los intereses públicos, de suerte que en el conflicto triunfen los primeros sobre los segundos, es volver contra el pueblo las funciones que él ha confiado y paga para que se le sirva [...] si los puestos públicos solo son de unos pocos personajes o de un grupo habrá caciquismo, habrá oligarquía, todo menos democracia... Hay que fundar carrera: la diplomática, la consular, la judicial, la militar, la docente o del profesorado, y otras por el estilo, como único medio de estimular el estudio, la honradez y el celo y formar verdaderos servidores de la patria. Valen infinitamente más pocos empleados, idóneos y bien retribuidos, que muchos mediocres y mal pagados. (Uribe, 1986 como se citó en Puentes, 2004, p. 64)

${ }^{8}$ Artículo 64 de la Constitución de 1886 "Nadie podrá recibir dos sueldos del Tesoro público, salvo lo que para casos especiales determinen las leyes" (Art. 64).

Ley 165 de 1938; allí se establecieron normas en las cuales se hace mención a las ramas del poder público y se regula el ámbito disciplinario, el régimen prestacional y el salarial. Igualmente se ocupó de la estabilidad en el empleo, salvo cuando el empleado era desvinculado por cometer una falta, luego de haberse agotado el procedimiento legal establecido y el derecho al ascenso de aquellos funcionarios que tenían altas calidades éticas y profesionales (Puentes, 2004). Dicho 
proyecto no hizo meya en la clase dirigente de ese momento, pues consideraban que con su implementación cualquier ciudadano podría quedarse de por vida en un cargo del Estado.

Posteriormente, en 1952 la Misión Currie, como se citó en Puentes (2004), concluyó que “[...] de 50.000 empleados gubernamentales existentes en la época, menos de 1.500 pertenecían a la carrera administrativa y un número reducido de los mismos había ingresado a ello por concurso de méritos" (p. 69). Esto significa que para ese momento la forma para ingresar al escalafón no era el concurso de méritos, sino la inscripción extraordinaria sin que se superara el sistema de méritos (Martínez, 2010).

Con el plebiscito de 1957, los partidos se pusieron de acuerdo para diseñar e implementar el sistema de la carrera administrativa elevándola al plano constitucional, por lo que posteriormente se expidió la Ley 19 de 1958, la cual creó el Departamento Administrativo del Servicio Civil, la Escuela de Administración Pública, la Sala de Consulta y Servicio del Consejo de Estado que brindaron una visión más organizada respecto de la administración de personal que se vinculaba al Estado.

Después, fue expedido el Decreto 1732 de 1960 en donde se dividieron los empleados vinculados al Estado en dos categorías: los de libre nombramiento y remoción y los de carrera; trayendo consigo el establecimiento del camino para elegir y vincular los funcionarios bajo los derechos a la igualdad y la superación del concurso de méritos.

Con la expedición del Decreto 2400 de 1968, se descentralizó la selección a las unidades de personal de los organismos que la conforman, se creó un reglamento de administración de personal. Se pasó de esta manera de un estatuto para funcionarios de carrera a un reglamento de administración de personal, es decir que se relegó el nivel territorial por lo que se aplicaba solamente al nivel nacional. 
En 1987 se expidió la Ley 61 de 1987, que clasificó los empleados de libre nombramiento y remoción como residuales de la siguiente de manera, definiéndolos como que son de carrera los empleos no señalados como de libre nombramiento y remoción, contempló también los conceptos del retiro, la insubsistencia, entre otros.

Ahora bien, fue en la Constitución política de 1991 donde la Asamblea Nacional constituyente consideró necesario definir el régimen meritocrático en su artículo 125 en el sentido que "los empleos en los órganos y entidades del Estado son de carrera. Se exceptúan lo s de elección popular, los de libre nombramiento y remoción, los de trabajadores oficiales y los demás que determine la ley".

En 1992 se promulgó la Ley 27 de 1992, en la cual se reguló lo atinente a la conformación de la Comisión Nacional del Servicio Civil, se reglamentó el sistema de carrera para los empleados del nivel nacional y territorial, se clasificaron empleos, se otorgaron competencias a las entidades para organizar sus sistemas de selección, se implementó el concepto de indemnización, reincorporación, se concedió protección a la maternidad y a las personas que se consideran poseen limitaciones físicas y se concedieron inscripciones extraordinarias a empleados del nivel territorial.

La Ley 443 de 1998 tuvo una vigencia fugaz, pues fue declarada inexequible por la Corte Constitucional al considerar que se violentaban los principios de la función pública descritos en la Constitución Política. Transcurridos cinco años se expide la Ley 909 de 2004 sobre el empleo público y la carrera administrativa. Sin que se hubiere otorgado una solución definitiva para que por fin se agote el concurso de méritos para proveer los cargos públicos de manera decisiva, por lo que se encuentran en su mayoría proveídos en provisionalidad. 
Posteriormente, se expide el Acto Legislativo No. 1 de 2008, el cual tenía como finalidad “incorporar de manera extraordinaria a quienes venían desempeñando los empleos de carrera administrativa en calidad de empleados en provisionalidad" (Martínez, 2010, p. 114); acto legislativo que fue declarado inexequible por la Corte Constitucional (Sentencia C 588, 2009), sentencia que además tuvo efectos retroactivos ordenando a la corte reanudar los concursos públicos que había suspendido y dejando sin efectos las inscripciones extraordinarias o automáticas en vigencia del acto legislativo.

\section{Carrera administrativa en el Estado Social de Derecho}

Fue la constituyente de 1991 la que le reconoció a la carrera administrativa una importante connotación en el Estado Social, pluralista y democrático de derecho, la cual se definió en los siguientes términos:

Un sistema técnico de administración de personal de los organismos y entidades del Estado cuyo fin es, además de la preservación de la estabilidad y del derecho de promoción de los trabajadores, garantizar la excelencia en la calidad del servicio y la eficiencia de la administración pública, y en general de las actividades estatales, ofreciendo igualdad de oportunidades para el ingreso, capacitación y ascenso del servicio público, con base exclusiva en el mérito y en las calidades de los aspirantes. (Sentencia C-837, 2003, párr. 1)

La carrera administrativa fue determinada como regla general de la administración pública en el artículo 125 de la Constitución Política de Colombia, equiparando la estructura estatal con los principios y fundamentos del Estado Social de Derecho, el cual se caracteriza por la prevalencia de los principios de libertad, justicia, igualdad y pluralidad; garantizándole de esta manera a todas 
las personas el derecho a acceder y permanecer en ejercicio de sus propios méritos al servicio del Estado (Sentencia C-126, 1996).

Lo anterior indica que la carrera administrativa es un principio constitucional dentro de nuestro Estado Social de Derecho, teniendo en cuenta tres criterios importantes definidos por las Corte Constitucional: un criterio de carácter histórico, el cual demuestra que a través del tiempo en el constitucionalismo colombiano se han presentado diferentes reformas constitucionales y legales encaminadas a otorgar prevalencia al sistema de méritos como la vía directa para acceder a la función pública de manera equitativa y transparente. Otro criterio de carácter conceptual, el cual determina la carrera administrativa como un principio constitucional que sirve de método prevalente para ingresar al servicio público y como criterio que determinara los requisitos y finalidades de la carrera administrativa como forma de vinculación a los cargos del Estado. Y un criterio de carácter teleológico que lleva implícita la obligación de interpretar de manera armónica lo dispuesto en la norma constitucional, es decir, el artículo 125, con otras normas de carácter superior que en definitiva establece a la función articular diversos fines valiosos que confluyen el orden constitucional, es decir que la carrera administrativa garantiza la realización de los objetivos esenciales y fundamentales de un Estado Social de Derecho (Sentencia C-553, 2010).

Lo anterior indica que la carrera administrativa conforma un principio del ordenamiento jurídico superior y de Estado Social de Derecho, en aras de ejecutar la función administrativa y proteger el interés general bajo los principios de igualdad, moralidad, eficacia, economía, celeridad, imparcialidad y publicidad. Así mismo, garantiza el cumplimiento de los fines esenciales del Estado, el derecho de participación en la conformación, ejercicio y control del poder político, a través del acceso a cargos públicos, así como los derechos constitucionales a la igualdad y los principios mínimos fundamentales de una relación laboral. 
La Constitución Política de Colombia de 1991 consagra tres disposiciones referidas a la carrera administrativa: en primer lugar, el artículo 123, el cual define como servidores públicos todas aquellas personas que prestan su servicios al Estado en calidad de miembros de corporaciones públicas, como empleados y trabajadores del mismo y de sus entidades descentralizadas territorialmente y por servicios. En segundo lugar, el artículo 150 numeral 23, que autoriza al Congreso de la República para expedir las leyes que regirán el ejercicio de las funciones públicas; finalmente, el artículo 125, el cual consagra e implementa el régimen de la carrera administrativa como regla general para proveer los cargos públicos dentro de los órganos y entidades del Estado.

La Corte Constitucional ha indicado que existe:

Una relación intrínseca entre la carrera administrativa y el cumplimiento de los fines esenciales de la administración pública, al punto que según la Corporación, el fundamento constitucional de la carrera administrativa se encuentra contenida en los artículos 125 y 209 superiores ya que, en ausencia de los criterios de mérito y eficiencia la función administrativa no puede estar al servicio de los intereses generales ni podrá ser desarrollada con base en los principios de igualdad, moralidad, eficiencia, economía, celeridad, imparcialidad y publicidad. (Sentencia C-288, 2014, numeral 3.4.2.)

Esta corporación ha indicado también que además del objetivo amplio de buscar la materialización del Estado Social de Derecho a través de una estructura pública, la carrera administrativa busca garantizar el cumplimiento de los fines estatales en la medida que la función pública pueda ser ejecutada por personal ampliamente capacitado y seleccionado luego de superar el concurso de méritos para determinar su ingreso, permanencia, ascenso y retiro del cargo, bajo el cumplimiento de los principios de eficacia, eficiencia, moralidad, imparcialidad y transparencia. Se garantiza así el servicio a la comunidad, la satisfacción del interés general y de esta manera se 
evitan los vicios del clientelismo, favoritismo y nepotismo (Sentencia C-553, 2010; Sentencia SU$539,2012)$.

Por otro lado, se garantiza la preservación y vigencia de los derechos fundamentales de las personas de acceder al desempeño de funciones y cargos públicos para ejercer sus derechos al trabajo a la igualdad, entre otros amparados en una estabilidad y posibilidad de promoción, según la eficiencia en el cumplimiento de sus funciones, pues no se trata de una permanencia en el cargo por razones ajenas a la efectividad de los buenos resultados (Sentencia C-195, 1994).

En este orden de ideas, en la exposición de motivos de la Ley 909 de 2004 se estableció como finalidad de la carrera administrativa:

Crear las condiciones institucionales para que se pueda construir un servicio civil de naturaleza profesional y que sea, además, uno de los referentes del programa de renovación del sector público [...] El principio de mérito no se detiene exclusivamente en los contornos del empleo público de carrera, sino que extiende su radio de acción a los puestos de gerencia pública. (Mendoza, 2015, p. 7)

La ineficiencia y la corrupción como factores perturbadores de nuestro ordenamiento jurídico e institucional tiene fundamento en el carácter parcializado y poco cualificado del ingreso y en el desempeño de quienes prestan sus servicios al Estado, en especial de los funcionarios que realizan labores de dirección, representación y política institucional, por lo cual se hace necesario un sistema obligatorio de meritocracia, incluyendo ciertos cargos de dirección. (González, 2010, pp. 153-154).

Paralelamente, la Sentencia C-563 de 2000 en su momento consideró:

El régimen de carrera administrativa, tal como lo concibió el Constituyente de 1991, impulsa la realización plena y eficaz de principios como igualdad e imparcialidad, pues se 
sustenta en la promoción de un sistema de competencia a partir de los méritos, capacitación y específicas calidades de las personas que aspiran a vincularse a la administración pública; sólo cumpliendo esos objetivos, que se traducen en captar a los mejores y más capaces para el servicio del Estado, éste está en capacidad de garantizar la defensa del interés general, pues descarta de manera definitiva la inclusión de otros factores de valoración que repugnan a la esencia misma del Estado social de derecho.

(Ap. VI)

\section{Proceso de selección en la carrera administrativa}

Como se ha indicado precedentemente, la provisión de cargos públicos y el ascenso en los mismos se realiza a través del concurso de méritos, los cuales son abiertos para aquellas personas que acrediten los requisitos exigidos para el cumplimiento de las funciones del cargo a proveer, imperando en dicho concurso los principios de igualdad y de mérito (González, 2010).

La Ley 909 de 2004 en armonía con el artículo 130 de la Constitución Política de Colombia dispone que "la competencia para adelantar los concursos o procesos de selección de las personas idóneas con las cuales se proveerán los cargos públicos le corresponde a la Comisión Nacional de Servicio civil". Esta entidad, por sus competencias, tiene la obligación de proteger el sistema de mérito en la función pública en Colombia bajo los principios de imparcialidad, igualdad y objetividad definida como un órgano autónomo e independiente, con personería jurídica, autonomía administrativa, patrimonial y técnica que no hace parte de ninguna de las ramas del poder público.

Las funciones de la Comisión Nacional del Servicio Civil se materializan a través de la celebración de convenios interadministrativos, contratos suscritos con entidades públicas o 
privadas o instituciones de educación superior acreditadas para tal fin. Los costos para la realización de los concursos están a cargo de los presupuestos de las entidades que requieren de la provisión de cargos para el cumplimiento de los fines esenciales del Estado.

Las etapas de la selección en los concursos públicos se encuentran previstas en la misma Ley 909 de 2004. Se trata de las siguientes:

1) Convocatoria: Se describe como aquella fase en la cual "se establecen las bases del concurso, es decir todos aquellos factores que han de evaluarse, así como los criterios de ponderación, aspectos que aseguran el acceso en igualdad de oportunidades al aspirante" (Sentencia T-604, 2013, párr. 5). Al respecto debe indicarse que la Sentencia C-733 de 2005 de la Corte Constitucional declaró inexequible el artículo 56 de la Ley 909 de 2004, que le reconocía a los provisionales dentro del concurso de méritos, su experiencia, conocimiento y antigüedad en el cargo, lo cual para algunos generaba privilegios con relación a las otras personas que concursaban sin haber sido servidores públicos en la misma entidad, vulnerándose así derechos y principios constitucionales como el de la igualdad y el acceso a cargos y funciones públicas.

2) Reclutamiento: Se determina quiénes de las personas inscritas en el concurso de méritos luego de presentada la convocatoria cumplen con los requisitos o condiciones objetivas mínimas señaladas en la convocatoria para acceder a las pruebas de aptitud y conocimiento como la edad, nacionalidad, profesión, títulos, experiencia, antecedentes penales, disciplinarios y fiscales. (Sentencia T-604, 2013, párr. 6)

Por lo tanto, en esta etapa se busca garantizar la inscripción del mayor número de aspirantes que reúnan los requisitos para el desempeño de los empleos objeto del concurso.

3) Pruebas: Aquellos instrumentos de selección que tienen como finalidad de apreciar la capacidad idoneidad y adecuación de los aspirantes a los diferentes empleos que se convoquen, así 
como establecer una clasificación de los candidatos respecto a las calidades requeridas. La valoración de estos factores se efectuará a través de medios técnicos, los cuales deben responder a los criterios de objetividad e imparcialidad. (González, 2010, p. 154)

Igualmente, las pruebas que se practiquen tienen el carácter de reservadas y solo son de conocimiento de las personas que indique la Comisión Nacional de Servicio Civil. Luego de analizadas las pruebas en lo que respecta a la capacidad e idoneidad personal de cada uno de los aspirantes, se garantiza el acceso de los mejores en cuanto al mérito corresponde; sin embargo, ha de tenerse en cuenta que no solo cuentan aspectos relacionados con conocimientos, trayectoria, entre otros atributos del aspirante, también su perfil psicológico, su personalidad, sus valores, la perspectiva que tenga frente a su moral, su forma de relacionarse con el entorno laboral que le corresponda.

4) Lista de Elegibles: una vez agotada la etapa de aplicación de las pruebas a los aspirantes la Comisión Nacional de Servicio Civil o la entidad contratada, elaborará en estricto orden de mérito la lista de elegibles con vigencia de dos años. Así lo dispone el artículo 11 literal e) de la Ley 906 de 2004, en el cual señala que dentro de las funciones de la Comisión está la de conformar, organizar y manejar el banco nacional de lista de elegibles de las personas que hayan superado las pruebas formuladas y de esta manera impedir la injerencia de maquinarias corruptas que pretendan evadir los principios de la administración pública, pero sobre todo los constitucionales como la igualdad y el predominio del sistema de méritos. Por esta razón, las personas que se vinculen al sistema de carrera administrativa serán inamovibles, salvo que, por incumplimiento en sus deberes y obligaciones, obtengan una calificación insatisfactoria.

Lo anterior permite concluir que al elaborarse la correspondiente lista de elegibles esta adquiere el carácter de acto administrativo generando situaciones jurídicas particulares para quienes tengan 
que ver con esta. Así lo indica el literal f) de la norma mencionada, que dentro de las funciones de la Comisión Nacional de Servicio Civil dispone la de remitir a las entidades de oficio o a solicitud de los nominadores, las listas de las personas conformadas por las personas que superaron el correspondiente proceso preestablecido para efectos de proveer los cargos en carrera administrativa que se encuentran vacantes de conformidad con la información que repose en los bancos de datos.

5) Evaluación y calificación del desempeño de los empleados vinculados en carrera administrativa: como se vislumbra, el sistema de méritos tiene como finalidad que la permanencia del personal que ejerce funciones públicas se encuentre condicionada a su desempeño ajustado a los fines de la entidad. Es la misma Ley 906 de 2004 la que indica los principios que deben regir la permanencia en el acto de evaluación del desempeño. Ellos son el mérito, el cumplimiento integral de las funciones y obligaciones preestablecidas, y el cumplimiento de las normas que rigen la función pública. Bajo el concepto del principio de legalidad es claro en este caso que el desempeño de los empleados de carrera debe ser evaluado y posteriormente calificado con base en los presupuestos y medidas prestablecidas para que finalmente el resultado arrojado de la evaluación sea la calificación que corresponde a la anualidad, que deberán incluir dos evaluaciones parciales al año. Sin embargo, si durante este periodo el jefe del organismo recibe información debidamente soportada de que el desempeño laboral de un empleado es deficiente, podrá ordenar por escrito que se le evalúen y califiquen sus servicios de forma inmediata. Sobre la evaluación definitiva del desempeño proceden los recursos de reposición y apelación. (Concepto 14651, 2016, Art. 38)

6) Retiro de los empleados vinculados en carrera administrativa: teniendo en cuenta que el sistema de méritos ha sido adoptado en varias legislaciones, incluyendo la colombiana, para evitar la corrupción y el clientelismo, no existe el carácter discrecional que impera en el régimen de los 
empleados de libre nombramiento y remoción, sino que el retiro debe cimentarse en la concurrencia de unas causales contempladas taxativamente en la norma constitucional y legal, claro está, luego de agotado el correspondiente procedimiento.

Por su parte, las causales contempladas en la Ley 906 de 2004 para que sea procedente el retiro de servidores vinculados en carrera son las siguientes:

(i) La declaratoria de insubsistencia como consecuencia del resultado no satisfactorio en la evaluación de desempeño laboral, (ii) por renuncia regularmente aceptada, (iii) por pensión de jubilación, por invalidez absoluta o por edad de retiro forzoso, (iv) por destitución como consecuencia del proceso disciplinario, (v) por declaratoria de vacancia en caso de abandono del cargo, (vi) por decisión judicial, (vii) por supresión del empleo y (viii) por muerte. (Ley 906, 2004, Art. 41)

Asimismo, la Corte Constitucional declaró inexequible la causal por razones del buen servicio, señalada en el literal C del artículo 41 de la Ley 909 de 2004, por cuanto en el sistema de carrera el nominador no puede tener discrecionalidad en la facultad de nominación y remoción, como quiera que esta es reglada. El retiro de los servidores de carrera está sometido a las causales fijadas en la ley, y no puede otorgarse facultades generales que puedan generar desviaciones contra los principios de la carrera como el mérito y la igualdad de oportunidades.

Recientemente fue expedido el Decreto 051 de 2018, mediante el cual se ordena a los jefes de personal del sector público para reportar los empleos vacantes e indica además que estos deben ser proveídos mediante el concurso de méritos, para que las entidades correspondientes en asocio con la Comisión Nacional del Servicio Civil participen de manera armoniosa y conjunta en la planeación del concurso de méritos para lo cual y según lo dispuesto en el estatuto orgánico de presupuesto EOP y el Techo del Marco de Gasto de Mediano Plazo, las 
entidades del nivel nacional deberán priorizar el gasto para adelantar los concursos de méritos y que los cargos que se sometan a concurso deberán contar con el respectivo certificado de disponibilidad presupuestal. Con la expedición de dicho decreto se reitera la inminente celebración de concurso de méritos para proveer los cargos de las diferentes entidades de orden nacional y territorial, por lo que es necesario analizar la situación de las personas vinculadas en provisionalidad a cargos del Estado y que gozan de protección constitucional como lo son las madres y padres cabeza de familia. 


\section{Capítulo 2. La provisionalidad en Colombia}

Para ocuparnos del sistema de la provisionalidad (regla excepcional) en Colombia, es necesario traer a colación los fundamentos jurídicos que la rigen. En este marco se tratará el tema de la estabilidad reforzada, siendo necesario, en primera instancia, definir la función pública a la luz del ordenamiento jurídico. Esta se entiende como aquel conjunto de relaciones laborales entre el Estado y sus servidores que desempeñan las funciones contempladas en la Constitución Política, en la Ley o un Reglamento, es decir que es aquella actividad realizada en cabeza de personas naturales en nombre del Estado, cuyo objetivo es el cumplimiento de los fines esenciales del mismo (Sentencia del Consejo de Estado del 23 de febrero, 2006).

\section{Fundamentos jurídicos de la provisionalidad}

Como ya se había referido, desde el año de 1938 con la ley 165 se estableció y reguló el sistema de la carrera administrativa como aquel procedimiento general a través del cual los cargos que comprenden la estructura del Estado han de ser proveídos luego de que los aspirantes a ocuparlos superen el concurso de méritos establecido. Se garantiza así que el personal seleccionado posea la suficiente idoneidad para el cumplimiento de los fines esenciales del Estado. Sin definir abiertamente la provisionalidad en dicha norma se indicó:

“Establecer y regular las condiciones de acceso al servicio público, de ascensos por mérito de antigüedad, y de jubilación, retiro o despido” y además "en ningún caso de afiliación política de los ciudadanos podrá determinar su nombramiento para un empleo o cargo público de carrera administrativa destitución.”. 
Dichos conceptos tuvieron aplicación constitucional directa en la Carta de 1886 expidiéndose como consecuencia la Ley 19 de 1958 reglamentada en el Decreto 1732 de 1960 en el que por primera vez se hizo referencia a los nombramientos en provisionalidad. Luego se expidió la Ley 65 de 1967 con la cual se facultó al presidente para modificar las normas que clasificaban los empleados en el andamiaje de la carrera administrativa.

Como consecuencia de lo anterior se expidió el Decreto 2400 de 1968 y el 1950 de 1973 en donde se estableció otra forma de vinculación excepcional a la administración como lo es la provisionalidad y la forma de desvinculación a través de la insubsistencia mediante acto administrativo discrecional.

Con la constitución de 1991 como se indicó en el capítulo que antecedió se estableció que los empleos en las entidades públicas son de carrera, que su vinculación se materializa al superar el concurso de méritos y que el retiro de los mismos se dará por calificación no satisfactoria en el desempeño del empleo, por violación al régimen disciplinario y por las demás causales previstas en la Constitución o la Ley.

La Corte Constitucional en sentencia T-147 de 2013 M.P Jorge Ignacio Pretelt Chaljub indicó que como el procedimiento para proveer los cargos de manera definitiva no era expedito, el legislador autorizó a los nominadores para que como medida transitoria y excepcional se diera una vinculación por encargo o provisionalidad. 
Continuando con la natarrativa cronología de la evolución de la figura de la provisionalidad en el engranaje jurídico, encontramos que luego de la Constitución de 1991 fue expedida la Ley 27 de 1992 en donde en su artículo 10 indicó que la provisión de empleos de libre nombramiento y remoción se haría por nombramiento ordinario y que mientras se efectuaba la selección para ocupar cargos de carrera, los empleados inscritos en el escalafón tendrían derecho preferencial a ser encargados de dichos empleos, claro está si los aspirantes cumplían con los requisitos establecidos y que de no ser esto posible podría acudirse a la figura de los nombramientos en provisionalidad.

La Ley 443 de 1998 derogó la Ley 27 de 1992, y los demás decretos reglamentarios que regulaban el sistema de la carrera administrativa, las modalidades de vinculación del personal que tienen a su cargo y el cumplimiento de los fines de la administración pública agregaron a la clasificación de los cargos los de elección popular y los de libre nombramiento y remoción, así como los vinculados en provisionalidad mientras se surtía el proceso de selección para proveer los empleos en carrera.

También se dijo que el nombramiento provisional es procedente cuando un cargo de carrera administrativa se encuentra en vacancia definitiva y este no puede ser proveído con un funcionario que se encuentre en carrera (no superior a cuatro meses), cuando este es ascendido, se produce la vacancia o cuando el nombramiento en provisionalidad o encargo se produjera solo en el periodo de prueba o en el término necesario para superarlo.

Con la Ley 909 de 2004 que derogó la Ley 443 de 1998, en su artículo 23 dispone que la regla general es que "los nombramientos serán ordinarios, en periodo de prueba o ascenso sin perjuicio de lo establecido en las carreras especiales" (Ley 909, 2004, Art. 23). Respecto de las vacancias la Ley 443 de 1998 las clasificó como definitivas y temporales. En el caso de las primeras el artículo $8^{\circ}$ dispuso que "en caso de vacancia definitiva, el encargo o el nombramiento provisional solo 
procederá cuando se haya convocado a concurso para la provisión del empleo" (Ley 443, 1998, Art. 8). Ahora bien: Mientras se surte el proceso de selección convocado para proveer empleos de carrera, los empleados que superaron el concurso de meritos, tendrán derecho preferencial a ser encargados de tales empleos, si acreditan los requisitos para su desempeño. Sólo en caso de que no sea posible realizar el encargo podrá hacerse nombramiento provisional. (Ley 443, 1998, Art. 8) En consecuencia, estos nombramientos tendrán carácter provisional, cuando se trate de proveer transitoriamente empleos de carrera con personal no seleccionado mediante el sistema de mérito. Es más, el parágrafo de esta misma disposición señala que "salvo la excepción contemplada en el artículo 10 de esta Ley, no podrá prorrogarse el término de duración de los encargos y de los nombramientos provisionales, ni proveerse nuevamente el empleo a través de estos mecanismos" (Ley 443, 1998, Art. 8). De otra parte, respecto de las vacancias temporales, el artículo 9 de la misma Ley, dispuso:

[Que] la provisión de los empleos por vacancia temporal como de los empleos de carrea cuyo titulares se encuentren en situaciones administrativas que impliquen la separación temporal de los mismos, sólo podrán ser provistos en forma provisional por el tiempo que duren aquellas situaciones, cuando no fuere posible proveerlos mediante encargo con empleados de carrera. (Ley 443, 1998, Art. 9)

A su turno, el artículo 70 de la Ley 938 de 2000 en su texto original estableció que la provisión de un cargo de carrera se efectuaría mediante un nombramiento en propiedad, una vez superado el periodo de prueba, y que cuando ello no fuera posible, se procedería al nombramiento mediante la figura del encargo, atendiendo los requisitos y el perfil correspondiente. Igualmente, esta disposición determinó que excepcionalmente, cuando fuera posible proveerlo en la forma descrita, 
se procedería al nombramiento en provisionalidad, el cual en ninguno de los casos produciría los derechos de carrera.

Con todo, dicha norma fue derogada por el artículo 121 del Decreto 20 de 2014, y en lo que tiene que ver con el inciso primero fue declarado exequible por la Corte Constitucional "en el entendido de que a más tardar el 31 de diciembre de 2008, la Fiscalía General de la Nación deberá haber culminado la aplicación del sistema de carrera mediante los concursos públicos de méritos correspondientes" (Sentencia C-279, 2007, párr. 6). Esto en razón a que el concurso de méritos cumple una doble función: por un lado, garantiza la protección al derecho de acceso al desempeño de funciones públicas en condiciones de igualdad como el derecho a la estabilidad laboral y, por otro lado, vela por el óptimo funcionamiento del servicio público, principio que debe ser protegido y garantizado por una de las entidades más importantes como lo es la Fiscalía General de la Nación, en donde se impulsan y definen situaciones determinantes.

La provisionalidad posee tres características esenciales. La primera es la discrecionalidad, en tanto que el nominador goza de la facultad de designar al empleado y, de la misma manera, la tiene para desvincularlo mediante acto administrativo, acto respecto del cual ha surgido el gran interrogante de si debe o no, ser motivado.

Una segunda característica es la excepción y transitoriedad, en tanto que la regla general es el agotamiento del concurso de méritos, por lo cual la provisionalidad posee una creación transitoria encaminada a garantizar la prestación del servicio público mientras se proveen los cargos de carrera administrativa. Lo anterior para indicar que los cargos que se proveen bajo la modalidad de la provisionalidad tienen carácter excepcional y discrecional, puesto que para su nombramiento basta con la verificación de los requisitos que demanda el cargo frente al perfil del aspirante, sin superar el proceso exhaustivo que se surte para la escogencia de los cargos de carrera administrativa. 
En tercer lugar, se encuentra la discrecionalidad en la forma de desvinculación de los empleados a través de un acto administrativo, el cual se profiere sin mayor motivación. Sin embargo, es necesario advertir que se dio un paso importante al respecto, dado que anteriormente el acto administrativo discrecional se profería sin que obrara en su contenido motivación alguna, circunstancia que tuvo amplio debate por varios años y que ocasionó un enfrentamiento jurídico entre las altas cortes: por una parte, la Corte Constitucional en sus diversos fallos reconoció la obligación de motivarlos en ejercicio del derecho al debido proceso y derecho a la defensa del declarado insubsistente; por otra parte, el Consejo de Estado mantuvo una posición contraria, puesto que en su momento consideró innecesaria la motivación, dada la naturaleza de la modalidad de vinculación excepcional. El estudio de este debate, central para lograr los objetivos de la presente investigación, se retomará posteriormente.

Sin lugar a dudas, el origen de la figura excepcional de la provisionalidad deviene de los vacíos jurídicos y técnicos dentro de la estructura de la carrera administrativa, en donde al no surtirse el procedimiento preestablecido, en el momento que lo amerite por falta de personal, es inminente acudir a la figura de la provisionalidad para proveer los cargos vacantes, sin dejar de lado los intereses políticos en donde en algunas ocasiones se ofrecen cargos cuya vinculación es excepcional.

La provisionalidad es una forma de nombramiento para proveer empleos en casos de vacancia definitiva o temporal, producida por ausencia del titular, que se motiva en razones administrativas y que tienen carácter pasajero. Lo que se observa en Colombia es que el nombramiento provisional que era una forma excepcional, que permitía agilidad en la provisión de empleos de carrera administrativa, cuando era necesario por las condiciones temporales de la vacancia producida, se ha ido convirtiendo en la regla general, 
desvirtuando la obligatoriedad de la carrera administrativa, que tiene consagración constitucional y legal. (Bernal, 2010, p. 11)

Así mismo, Martínez (2010) describió la situación que vive la mayoría de las personas que laboran con el Estado colombiano en la actualidad, indicando que aunque en nuestro país la primera ley formal sobre carrera administrativa fue expedida en 1938, solo hasta el año 2004 se "intentó" realizar "dos amplios concursos de méritos", con el fin de vincular más de cien mil empleados al Estado, lo que a la postre no se ha cumplido.

Ahora bien, la Corte Constitucional en Sentencia T- 147 de 2013 M.p Jorge Ignacio Pretelt Chaljub realizó varias precisiones importantes respecto de la figura de la provisionalidad como forma excepcional de vinculación al Estado, fue clara en advertir que la naturaleza de los cargos provisionales difiere de los cargos de carrera administrativa y de los empleados de libre nombramiento y remoción, que los empleados vinculados en provisionalidad no acceden directamente al statu quo de los empleados que superaron el concurso de méritos, sin embargo tiene derecho a que los actos administrativo mediante los cuales se declaran la insubsistencia sean motivados para que de esta manera puedan ser controvertibles ante el juez natural.

Pero también se indicó en la Sentencia que los empleados vinculados en provisionalidad tampoco pueden asimilarse a los vinculados bajo la modalidad de libre nombramiento y remoción pues el nombramiento no se finca en la confianza para ejercer funciones de dirección o manejo sino para garantizar la prestación del servicio, por ende el cumplimiento de los fines esenciales del Estado. 


\section{Estabilidad inmediata o reforzada}

Se define la estabilidad reforzada como aquella figura a la que se acude para ofrecer protección laboral a aquellas personas que tienen una condición especial y que de no tenerse en cuenta puede ocasionar la vulneración de sus derechos fundamentales y constitucionales. Dicha protección se ha materializado a través de la expedición de las leyes expedidas por el Congreso y los pronunciamientos de la Corte Constitucional, a través de los cuales buscan la defensa de los derechos de las personas con condición de discapacidad y mujeres embarazadas.

Segùn Vasquez 2009 indica que el legislador colombiano hubiere establecido algunos instrumentos en distintos niveles de optimización que buscan garantizar no solo la estabilidad laboral de aquellas personas que se encuentran inscritas en carrera administrativa, sino de aquellas otras que aunque no se encuentran en tales condiciones, gocen de cierto grado de estabilidad relativa, en otras palabras, dentro del Estatuto del Empleo, la Carrera Administrativa y la Gerencia Pública (Ley 909 de 2004 y demás disposiciones reglamentarias) (p.92).

Para estas personas en condición especial se ha indicado que aunque el empleado pudiese argumentar los motivos de justa causa para el despido, la normatividad y la jurisprudencia los protege. En estos casos no es posible realizarse la destitución, pues se garantiza la permanencia de los trabajadores que poseen estas condiciones particulares y se impide que estas sean el motivo principal del despido.

También se define la estabilidad intermedia o reforzada como un fuero circunstancial que protege a los empleados cuando se encuentran en alguna situación de vulnerabilidad establecida por la norma. 
En las situaciones de los servidores públicos nombrados en provisionalidad, además de gozar de las protecciones generales que tienen los demás trabajadores que se encuentran en situación de disminución o vulnerabilidad, tienen el derecho a que obligatoriamente se motive la decisión de declaratoria de insubsistencia de su nombramiento.

Según Torres y Ruiz los empleados en provisionalidad en Colombia han obtenido gran importancia y que por ello el legislador buscó con la ley 909 de 2004, brindarles una mayor estabilidad, permitiéndoles acceder a la carrera administrativa otorgándoles una serie de ventajas al momento de participar en el concurso de méritos que por lo tanto han adquirido

Según González (2010), sobre el tema existen dos posiciones que conllevaron a un "choque de trenes" entre la Corte Constitucional y el Consejo de Estado: por un lado, la Corte Constitucional sostiene que los servidores públicos provisionales que ejercen cargos de carrera "gozan de estabilidad relativa", debido a la naturaleza del cargo, el tipo de funciones que ejercen y siempre que cumplan con los requisitos exigidos para el ejercicio del cargo, al tiempo que no se asimilan en caso de retiro a los de libre nombramiento y remoción. Indica, además, que los servidores públicos se pueden desvincular cuando la entidad ha convocado el concurso de méritos correspondiente para la provisión definitiva del cargo y que la estabilidad se puntualiza en la obligación del nominador de indicar de manera específica los motivos de su declaración de insubsistencia, requisito que si se obvia es causal de nulidad del acto administrativo correspondiente, en desarrollo de los principios constitucionales del Debido Proceso y el Derecho de Defensa, en sede administrativa.

Por otro lado, el Consejo de Estado ha sostenido que los servidores públicos nombrados en provisionalidad, "no gozan" de ninguna estabilidad, debido a que su vinculación se respalda en la “discrecionalidad del nominador"; por lo tanto, de la misma manera puede ser retirado, ya que el 
fuero de estabilidad solo es para los servidores que se encuentran inscritos en carrera administrativa.

Ahora bien, González (2010) considera que la posición de la Corte Constitucional es la más acertada, en tanto que mientras el cargo no se haya provisto definitivamente por medio de un concurso de méritos, los servidores públicos con nombramiento provisional que ejercen cargos de carrera pueden, a través de la acción de tutela, ser reintegrados en caso que se demuestre vulneración de derechos fundamentales, como sucede cuando se afecta el mínimo vital, los derechos a la igualdad y al debido proceso, entre otros aspectos. En este orden de ideas, son varias las decisiones de la Corte Constitucional, por medio de las cuales se ha realizado unificación de jurisprudencia sobre el tema y en donde ordena "revocar" las sentencias del Consejo de Estado en procesos de acción de nulidad y restablecimiento del derecho, al igual que en acciones de tutela, por medio de las cuales se ordena el reintegro de servidores públicos provisionales desvinculados, sin el cumplimiento de los requisitos, con el correspondiente reconocimiento de pago de salarios y prestaciones desde su retiro hasta su reintegro.

Se evidencia de lo anterior que con los diversos casos tratados en sede judicial y constitucional en donde se ha decantado el tema de la provisionalidad, la acción de tutela ha sido el mecanismo más importante mediante el cual los vinculados de manera excepcional pueden buscar el amparo de los derechos que consideran han sido vulnerados con ocasión a los despidos mediante declaración de insubsistencia, logrando en la mayoría de casos el reintegro a sus empleos. Por esto fue necesario limitar la acción a casos taxativos y disponer que el mecanismo pertinente era la acción de nulidad y restablecimiento del derecho en sede de lo 
contencioso administrativo ${ }^{5}$. En Sentencia T-257 de 2006 la Corte Constitucional (Magistrado

Ponente Manuel José Cepeda Espinosa) estableció los requisitos para la instauración de la acción de tutela ${ }^{6}$ indicando además que se debe tratar de un funcionario vinculado en provisionalidad a alguna entidad del Estado, que el empleo que se encontraba ocupando sea un empleo de carrera administrativa, que se haya desvinculado posteriormente al empleado mediante acto administrativo sin motivación y que se haya provisto ese mismo empleo con un funcionario vinculado también a la entidad en provisionalidad.

Lo anterior indica la forma a través de la cual quien considera vulnerados sus derechos logre que la entidad nominadora motive el acto administrativo que lo declara insubsistente según el fallo de tutela que haya instaurado en sede judicial, o a través de la acción de nulidad y restablecimiento del derecho controvertir el acto administrativo que declara su insubsistencia.

\footnotetext{
${ }^{5}$ Sentencia T-343 de 2001 indicó lo siguiente: "La acción de nulidad y restablecimiento del derecho, es el instrumento jurídico específico que puede utilizar el actor para solicitar de la Jurisdicción Contencioso Administrativo la declaratoria de nulidad del acto administrativo; esto es, para plantear su pretensión orientada a la pérdida de su eficacia jurídica por la ocurrencia de un vicio que afecta su validez (ilegalidad, incompetencia, forma irregular, etc.) y que, en consecuencia, se le restablezca en su derecho o se le repare el daño" (párr. 1).

Esta acción tiene por objeto:

La protección directa de los derechos subjetivos de la persona amparados en una norma jurídica y desconocidos por el acto administrativo. En ella se le brindan al actor todas las posibilidades probatorias para que demuestre la ilicitud del acto acusado y logre que se le restablezca en su derecho o se le repare el daño. (Sentencia T-343, 2001, numeral 2.4.1.)

${ }^{6}$ A). El perjuicio ha de ser inminente: "que amenaza o está por suceder prontamente". [...] B). Las medidas que se requieren para conjurar el perjuicio irremediable han de ser urgentes, es decir, como calidad de urgir, en el sentido de que hay que instar o precisar una cosa a su pronta ejecución o remedio tal como lo define el Diccionario de la Real Academia. [...] C). No basta cualquier perjuicio, se requiere que éste sea grave, lo que equivale a la gran intensidad del daño o menoscabo material o moral en el haber jurídico de la persona. [...] D). La urgencia y la gravedad determinan que la acción de tutela sea impostergable, (Sentencia T-343, 2001, numeral 2.4.2.)

Ya que tiene que ser adecuada para restablecer el orden social justo en toda su integridad. Si hay postergabilidad de la acción, ésta corre el riesgo de ser ineficaz por inoportuna.
} 
La misma Corte Constitucional en Sentencia T 147 de 2013 MP. Jorge Ignacio Pretelt Chaljub indicó que aunque las personas nombradas en provisionalidad disponen de la acción de nulidad y restablecimiento del derecho ante la jurisdicción contenciosa administrativa para que el caso en concreto sea analizado de fondo, dicho mecanismo no resulta suficientemente eficaz para la protección de sus derechos fundamentales, entre ellos el derecho al Debido Proceso, el respeto al Estado de Derecho, al principio democrático, y al principio de publicidad, al tratarse de una garantía mínima de control de la arbitrariedad de la administración.

\section{Actos administrativos que declaran la insubsistencia}

El acto administrativo, aunque no se encuentre definido expresamente en ninguna norma administrativa, puede definirse como aquella manifestación de voluntad de la administración que produce efectos jurídicos y que se profiere en ejercicio de la función administrativa. El contenido del mismo debe ser cierto, lícito y posible. La doctrina ha agregado que no debe ser lesivo en forma antijurídica para los intereses de un tercero.

La Corte Constitucional en la Sentencia C-069 de 1995 argumentó que "la existencia del acto administrativo está ligada al momento en que la voluntad de la administración se manifiesta a través de una decisión" (párr. 1), y que el acto administrativo desde el instante en que es producido por la administración lleva implícita la obligación de producir efectos jurídicos, es decir su eficacia, así como se encuentra ligado a su vigencia desde el momento de su expedición condicionada a la publicación (general) o notificación del acto (particular). 
Dentro de la clasificación de los actos administrativos se encuentran los discrecionales, bajo los cuales la administración ejerce su potestad plena, pues tal y como lo señala Marín (2007):

Es innegable que en algunos casos resulta forzoso dejar a la apreciación del órgano o funcionario algunos aspectos o problemas. Unas veces aquel tendrá la oportunidad para decidir, facultado para obrar o abstenerse, según las circunstancias; otras veces, la norma le dará opción para escoger alternativamente entre varias formas de decisión; en algunas ocasiones, la Ley solo fija los presupuestos de hecho que lo autorizan para poner en ejercicio la atribución de que se trata, dándole potestad para adoptar la decisión más favorable. (p. 15)

Pese a lo anterior, es necesario advertir que no existen facultades puramente discrecionales, pues se encuentran regidas estrictamente bajo normas constitucionales y legales. Por lo tanto, no existe en el ordenamiento jurídico colombiano discrecionalidad absoluta, teniendo en cuenta el modelo del Estado Social de Derecho, por ende la administración se encuentra limitada para evitar la arbitrariedad.

Para Pereira y Carrillo (2015) la discrecionalidad:

[Es] esencialmente una libertad de elección entre alternativas igualmente justas, o, si se prefiere, entre indiferentes jurídicos, porque la decisión se fundamenta en criterios extrajurídicos (oportunidad, económicos, etc.), no incluidos en la ley y remitidos al juicio subjetivo de la Administración. (p. 3)

En la actualidad el ordenamiento jurídico ha dotado a los actos administrativos adoptados por la administración pública de la presunción de legalidad para efectos de otorgarles seguridad jurídica y eficacia; sin embargo, el particular también cuenta con los mecanismos necesarios para desvirtuar dicha presunción para obtener el restablecimiento de sus derechos. 
Teniendo en cuenta lo anterior y de acuerdo a los pronunciamientos al respecto por parte de las altas cortes competentes para ello, así como la doctrina, se ha concluido que es necesaria la motivación del acto administrativo, dado que esta es una forma eficaz de reprimir la posibilidad de desviación de poder, aunque se catalogue el acto como discrecional. Ello no releva a la administración de la obligación de expresar los motivos que fundan su decisión, pero sobre todo de su deber de garantizar los derechos fundamentales de los involucrados (Sentencia C-734, 2000).

Así mismo, la motivación de los actos administrativos es una de las garantías al debido proceso, en tanto que al conocerse las razones fácticas y jurídicas tenidas en cuenta por la administración, el particular podrá ejercer su defensa en la sede contenciosa administrativa. La Corte Constitucional en Sentencia C-734 de 2000, concluyó:

La motivación de los actos administrativos es una garantía para los administrados en contra de la arbitrariedad [...] la discrecionalidad absoluta entendida como la posibilidad de adoptar decisiones administrativas sin que exista una razón justificada para ello, puede confundirse con la arbitrariedad y no es de recibo en el panorama del derecho contemporáneo. La discrecionalidad relativa, en cambio, ajena a la noción del capricho del funcionario, le permite a éste apreciar las circunstancias de hecho y las de oportunidad y conveniencia que rodean la toma de la decisión, concediéndole la posibilidad de actuar o de no hacerlo, o de escoger el contenido de su determinación, siempre dentro de las finalidades generales inherentes a la función pública y las particulares implícitas en la norma que autoriza la decisión discrecional. En este orden de ideas, [...] la necesidad de motivar el acto administrativo se erige como la mejor garantía para distinguir lo discrecional de lo arbitrario. (Ap. V) 
Ahora bien, volviendo a la provisionalidad, en principio se consideró que los empleados vinculados en dicha modalidad podían ser declarados insubsistentes sin motivación alguna. El Decreto 1950 de 1973, en su artículo 107 indica que "en cualquier momento podrá declararse insubsistente un nombramiento ordinario o provisional, sin motivar la providencia de acuerdo con la facultad discrecional que tiene el Gobierno de nombrar y remover libremente a sus funcionarios" (Decreto 1950, 1973, Art. 107). Pero quizás lo más importante es que es el mandato constitucional el que ordena como forma de vinculación a la función pública la carrera administrativa, es decir la superación del concurso de méritos que está claramente definido además por la Ley. Sin embargo, no es posible dejar de lado que también existen unos principios constitucionales, los cuales deben ser ampliamente garantizados en la forma de Estado (Social de Derecho), así como el derecho al debido proceso, de igualdad y al principio de legalidad.

Respecto de la insubsistencia como forma de desvinculación de los empleados en provisionalidad Younes (2005) señaló:

La declaratoria de insubsistencia es una medida, prevista por nuestra legislación, en favor de la administración y como tal amparada por la presunción de legalidad. Pero tal presunción es desvirtuable, probando que el acto de insubsistencia se hizo con abuso o desviación de las atribuciones propias del funcionario que lo expidió, situación que se da cuando el agente que la decreta persigue fines contrarios a los del buen servicio, que son obviamente los que deben buscar las autoridades investidas de esta facultad. (p. 404)

En lo que tiene que ver a los actos administrativos que declaran la insubsistencia de los empleados vinculados en provisionalidad, se encuentra que como ya lo ha indicado la Corte Constitucional en sus diferentes pronunciamientos que más adelante se traerán a colación, al no motivarse, existe un desconocimiento pleno al principio de legalidad (Sentencia SU-917, 2010), 
en tanto que la administración pública que se encuentra en cabeza de las diferentes entidades tiene la obligación de actuar conforme a la constitución, las leyes y los reglamentos. Por lo tanto, al nominador no le es dable desbordarse en sus funciones, pero sobre todo en sus facultades, es decir que sus decisiones no son individuales ni autónomas a los lineamientos preestablecidos.

Esto es indicativo de que los empleados vinculados en excepcionalidad, a pesar de que en principio no poseen las mismas prerrogativas de aquellos vinculados bajo la regla general, de todas maneras gozan de protección por parte de nuestro Estado Social de Derecho, sin que puedan ser removidos sin la motivación del acto administrativo que lo ordena.

La Corte Constitucional en Sentencia T- 147 de 2013 MP. Jorge Ignacio Pretelt Chaljub indicó que el acto administrativo mediante el cual se prescinde de los servicios de un empleados vinculado en provisionalidad debe cumplir con el principio de "razón suficiente" que implica que en el acto administrativo conste "Las circunstancias particulares, y concretas de hecho y de derecho, por las causales se decide remover a un determinado funcionario, de manera que no resulten válidas aquellas justificaciones indefinidas, generales y abstractas, que no predican directamente de quien es desvinculado".

Que por tanto una motivación constitucionalmente admisible es aquella en la que la insubsistencia se finca en unos argumentos estrictos y puntuales como los son la provisión definitiva del cargo una vez realizado el respectivo concurso de méritos; la calificación insatisfactoria del funcionario, la imposición de sanciones disciplinarias y "otra razón especifica atinente al servicio que está prestando". 
La motivación del acto garantiza al empleado el derecho fundamental al debido proceso, dado que al agotarse las prerrogativas mínimas el resultado de la actuación será legal, justa y equitativa bajo el marco legal preestablecido para ello. Como lo indica la Corte Constitucional,

Con la motivación del acto se garantiza también el derecho a la defensa del involucrado, evitando de una u otra manera el actuar arbitrario por parte de la administración, pues se le permite conocer las razones fácticas y jurídicas que tuvo el nominador para adoptar tal decisión y de esta manera pueda ejercer las acciones judiciales o más bien contenciosas (Sentencia C-371, 2011).

No obstante, para que el involucrado pueda ejercer su derecho al debido proceso, a la defensa y a exigir el cumplimiento del principio de legalidad, existe una actuación que da paso a la garantía de dichas prerrogativas y es la publicidad de los actos administrativos discrecionales, que obliga a la administración a comunicar, publicar o notificar sus decisiones para que los actos administrativos, en este caso los discrecionales, surtan efectos jurídicos. Como se indicó anteriormente, de la publicidad también depende que el afectado pueda controvertir el acto que considera viciado de nulidad ante la jurisdicción contenciosa administrativa (Sentencia SU-917, 2010).

\section{Posiciones del Consejo de Estado y la Corte Constitucional frente a la provisionalidad}

La provisionalidad ha sido uno de los temas que ha generado confrontación de criterios entre las altas cortes (Corte Constitucional y Consejo de Estado), lo que de una u otra manera puede haber dado lugar a cierta inseguridad e incertidumbre jurídica, en tanto que, por un lado, se ha dejado en claro que la provisionalidad como forma de vinculación excepcional no genera estabilidad laboral para el empleado, pero, por otro lado, no es viable a la luz del Estado Social de 
derecho que el trabajador sea desvinculado de su cargo con desconocimiento a sus derechos fundamentales al debido proceso, a la defensa y sobre todo a la prevalencia del principio de legalidad en todas las actuaciones del Estado.

La situación denominada por los medios de comunicación "choque de trenes" no solo se ha dado entre la Corte Constitucional y el Consejo de Estado, sino además dentro de esta última corporación. En efecto, entre las secciones del Consejo de Estado se han dado importantes diferencias, pues en algún momento la sección A consideraba que el acto administrativo mediante el cual se declaraba la insubsistencia del empleado vinculado en provisionalidad debía motivarse siquiera sumariamente, mientras que, por el contrario, la sección B consideraba que no era necesario la motivación del acto administrativo dada la naturaleza de la vinculación excepcional.

\section{Corte Constitucional}

Para la Corte Constitucional es más que claro que la provisionalidad es una forma de vinculación al Estado con carácter transitorio, siempre que no haya empleados de carrera que cumplan con el perfil y los requisitos para ocupar el cargo o que no haya lista de elegibles vigente para proveerlos. Sin embargo, para esta Corte también es clara la obligación de los agentes de cumplir a cabalidad con los fines y principios establecidos en el Estado Social de Derecho, por lo que ninguna actuación ha de ser autoritaria ni viciada por desviación de poder.

En este caso, la función de la Corte Constitucional es netamente garantista, es decir que se concentra en la protección de los derechos fundamentales de los involucrados frente a las actuaciones de los agentes o nominadores del Estado, por lo cual todo acto o actuación debe estar revestida de plena legalidad y con cumplimiento a las garantías constitucionales pregonadas en la 
Carta Magna. A continuación, se hará mención a algunos de los pronunciamientos más importantes proferidos por la Corte Constitucional en la materia.

En la Sentencia T-800 de $1998^{7}$ se indicó lo siguiente:

El nombramiento en provisionalidad de servidores públicos para proveer cargos con carácter de carrera administrativa, no se equipara al nombramiento en cargos de libre nombramiento y remoción, por lo cual el nominador no puede desvincular al empleado provisional con la misma discrecionalidad que posee para desvincular al de libre nombramiento y remoción, salvo que exista una causa que la justifique. (párr. 4)

También se advirtió allí que la provisionalidad se admite mientras se efectúa la selección para ocupar un empleo en carrera administrativa, por lo que la administración está obligada a convocar el respectivo concurso y así, por un lado, evitar la prolongada vinculación de funcionarios en cargos cuya provisión debe ser luego de superado el concurso de méritos y también evitar, por otro lado, que la administración se paralice por el hecho de que no hayan servidores públicos desempeñando funciones propias del cargo vacante.

En Sentencia T-884 de 2002 la Corte reiteró que los servidores provisionales no pueden ser desvinculados sin motivación del acto administrativo que así lo decide bajo el argumento de la discrecionalidad del nominador. Por lo tanto, es de obligatorio cumplimiento la motivación del

${ }^{7}$ Sentencia T-800/98 mencionó básicamente:

[Que] un funcionario que se encuentra ocupando un cargo de carrera administrativa en provisionalidad por más tiempo del autorizado por la Ley, debe ser desvinculado siempre y cuando la administración cumpla, por su parte, con la obligación de convocar el respectivo concurso de méritos para proveer definitivamente la plaza, pues de no darse tal correspondencia, los cargos estarían destinados gradualmente a quedarse vacantes, al no haber una designación oportuna del reemplazo. El derecho a la estabilidad laboral, representado en el hecho de que no puede ser desvinculada del cargo mientras no se configure una justa causa disciplinaria o se convoque el respectivo concurso de méritos, sí podría llegar a atentar contra derechos fundamentales. (párr. 5) 
acto administrativo que declara la insubsistencia en ejercicio de las garantías constitucionales del involucrado.

En la Sentencia T-610 de 2003 se reconoció la acción de tutela como aquella acción constitucional a la cual podían acudir los empleados vinculados en provisionalidad a cargos del Estado que fueron declarados insubsistentes sin que el acto administrativo que procede de esta forma haya sido motivado. De esta manera, el afectado puede no solo obtener su reintegro sino además generar la posibilidad de acudir a la vía jurisdiccional con el fin de contradecir el acto administrativo correspondiente. En consecuencia:

La falta de motivación de ese acto del Estado que retira del servicio a una persona nombrada en interinidad porque aún no se han hecho los concursos para ingresar a la carrera, es una omisión en contra del derecho porque la motivación es necesaria para el control de los actos administrativos que facilita la función revisora de lo contencioso - administrativo, y, por ende, la falta de motivación se convierte en un obstáculo para el efectivo acceso a la justicia (artículo 229). (Sentencia T-610, 2003, numeral 3.4 Ap. II)

Por su parte, la Sentencia C-733 de 2005 adujo:

La provisionalidad es una forma de vinculación al Estado de carácter precario mediante el cual, sin mediar concurso de méritos, se surte un cargo de carrera administrativa sin encontrarse inscrito en ella y por ende no es posible gozar de los mismos derechos que esta otorga. (Ap. VI)

Por consiguiente, el legislador no puede establecer que quienes se encuentren vinculados en provisionalidad ingresen automáticamente a la carrera administrativa, que para efectos de autorizar a las entidades públicas la prórroga de los nombramientos en provisionalidad ingresen inmediatamente en carrera. La provisionalidad es una situación jurídica especial que hace parte de 
cualquier carrera administrativa, pues en ocasiones la urgencia de prestar el servicio les impone la obligación de realizar los nombramientos en periodo de prueba o en propiedad.

De forma similar, la Sentencia T-961 de 2011 admitió la procedencia de la acción de tutela contra providencias judiciales, pero sobre todo hizo énfasis en la obligación que tiene el nominador de motivar los actos administrativos de desvinculación de servidores públicos que ocupen cargos de carrera en provisionalidad. Además, la Corte consolidó los criterios que venía desarrollando en aras de limitar el alcance de la orden de pagar salarios y prestaciones dejados de percibir como consecuencia de la declaratoria de insubsistencia. Hizo hincapié principalmente en las sentencias SU-917 de 2010 y T-656 de 2011 y como consecuencia de la declaratoria de nulidad del acto administrativo demandado, ordenó el reintegro del actor al cargo que venía desempeñando en provisionalidad hasta tanto se surtiera el correspondiente concurso de méritos, así como el pago de salarios y prestaciones a partir del momento en que se solicitó la protección de sus derechos fundamentales y hasta la fecha del reintegro o hasta que se produzca la vinculación del funcionario en propiedad.

Paralelamente, la Sentencia T-186/13 de 2012 destacó que debe darse relevancia al principio de igualdad que rige el ejercicio de la función administrativa, de tal forma que quienes provean los cargos de carrera presten atención a las características particulares de cada caso individual, pues pueden verse afectados derechos fundamentales. Por esta razón, se debe evitar incurrir en discriminación, optando por aquella que mejor garantice derechos, valores y principios constitucionales. Así pues, el camino adecuado no es retirar inmediatamente a quien ocupa el cargo en provisionalidad y este es un sujeto de especial protección constitucional, es decir se debe entrar a realizar una ponderación de principios y derechos fundamentales de las personas interesadas y afectadas por dicha situación. 
De igual forma, la Sentencia T-407 de 2016 reiteró que respecto al retiro de los servidores públicos vinculados en provisionalidad a cargos de carrera administrativa, es viable a la luz de la constitución una motivación coherente con la función pública en el Estado Social de Derecho; con lo cual se logra la protección al derecho al Debido Proceso y el acceso en condiciones de igualdad al servicio público:

A los funcionarios nombrados en provisionalidad en cargos de carrera no les asiste el derecho de estabilidad típico de quien accede a la función pública por medio del concurso de méritos, pero de ello no se desprende una equivalencia a un cargo de libre nombramiento y remoción, pues la vacancia no cambia la naturaleza del cargo. De allí que, en concordancia con el precedente de la Corporación, al declarar insubsistente a uno de dichos funcionarios, deben darse a conocer las razones específicas que lleven a su desvinculación, las cuales han de responder a situaciones relacionadas con el servicio prestado o al nombramiento en propiedad del cargo, de manera que no se incurra en una violación del derecho a la estabilidad laboral del servidor público en provisionalidad y, en consecuencia, de su derecho al debido proceso. (Sentencia T-407, 2016, numeral 4)

\section{Consejo de Estado}

El Consejo de Estado en lo que tiene que ver con la motivación de los actos administrativos que declaran la insubsistencia argumentó que pese a que los empleados vinculados en provisionalidad y que fungen en cargos de carrera administrativa no adquieren los mismos derechos de quienes superan el concurso de méritos, los actos mediante los cuales se declara su insubsistencia deben estar motivados y justificados en el interés general. A continuación, algunos de los fallos proferidos por dicho tribunal: 
En la decisión proferida por la Sección Segunda, Radicado No. 76001-23-31-000-1998-18340 de 2003 (Sentencia del 13 de Marzo de 2003) se indicó que el servidor público judicial nombrado en provisionalidad, antes que cobijarle algún tipo de estabilidad, le rodea una situación de doble inestabilidad, pues por una parte, al no pertenecer al sistema de carrera, puede ser desvinculado del servicio de manera discrecional por el nominador, y por otra parte, pueda ser desplazado por quien habiendo concursado tenga derecho a ocupar el cargo. Agrega que, por lo demás, de conformidad con los cánones legales aplicables a la carrera de la rama judicial, mientras se provee el empleo de carrera mediante concurso, dicho cargo se podrá proveer con nombramiento en provisionalidad y que esta circunstancia no implica que quien en esta forma ocupe el cargo queda bajo el gobierno de las normas que reglamentan el retiro del personal de carrera, porque así lo dispuso la ley.

Además, la permanencia del servidor público en el cargo por encima del término previsto en la ley no le genera a este ningún derecho de inamovilidad, ni al nominador la obligación de motivar el acto de insubsistencia, pues por esta circunstancia carece de la virtualidad para modificar la condición que legalmente tenía el demandante, la cual es la de estar nombrado en provisionalidad sin estar en ninguna estabilidad relativa. Lo contrario sería aceptar que el servidor goza de las garantías de carrera, sin estar ello señalado en la ley.

En la decisión del 12 de febrero de 2004 de la misma Sección Segunda (Radicado no. 080012331-000-2004-02778-01(0973-06)), se concluyó lo que sigue:

La facultad discrecional respecto de los empleados provisionales se impone al efectuar el nombramiento en tal carácter de provisionalidad, puesto que la transitoriedad de la designación mientras se realiza el proceso selectivo, autoriza a la administración realizar el nombramiento provisional. Al igual su retiro, pues tal discrecionalidad es el marco rector en esta clase de designaciones, en la medida que mientras el cargo clasificado como de 
carrera administrativa no haya sido provisto por el sistema selectivo, el empleado se encuentra en una situación precaria que no otorga fuero alguno de estabilidad. (Sentencia T-432, 2006, numeral 3 Ap. I)

Mediante Sentencia del 5 de febrero de 2004, la Sección Segunda precisó:

El nombramiento en provisionalidad tiene lugar mientras se realiza la designación por el sistema de concurso de méritos y que ello no implica que la persona provisionalmente nombrada no pueda ser removida del servicio, hasta tanto no se produzca el nombramiento provisto legalmente y que la provisionalidad es la forma de proveer los cargos para no interrumpir la prestación del servicio público. Con todo, esta modalidad no es generadora de fuero de estabilidad alguno para el funcionario que lo desempeñe, de tal modo que la entidad nominadora, mientras no exista lista de elegibles vigente y aplicable, puede ejercer la facultad discrecional en aras del buen servicio público. (párr. 91)

La figura de la provisionalidad, a la luz del ordenamiento legal y constitucional ha sido considerada por la jurisprudencia y la doctrina como el nombramiento realizado con la condición suspensiva que la ocupación de dicho empleo se hará hasta tanto no se realice la designación por el sistema de concurso de méritos. No obstante, a lo largo de las decisiones adoptadas por el Consejo de Estado, sea en calidad de ad-quo o ad-quem, esta corporación ha sido enfática en referir que el nombramiento no implica que la persona nombrada provisionalmente no pueda ser removida del servicio hasta cuando se produzca el nombramiento previsto legalmente, sino que simplemente constituye una forma de proveer los cargos para no interrumpir la prestación del servicio público, sin que se genere a través de dicha modalidad de vinculación fuero de estabilidad para el funcionario que lo desempeñe. 
Las anteriores consideraciones que fueron precisadas por el Consejo de Estado, Sección Segunda, Subsección A, en providencia del 27 de octubre de 2005, en la cual agregó que en efecto el funcionario nombrado en provisionalidad, al no pertenecer al régimen carrera administrativa, puede ser desvinculado del servicio de manera discrecional por el nominador, no siendo entonces aplicable procedimiento alguno de los establecidos para el retiro de este tipo de funcionarios, ni motivando el acto de retiro del servicio.

Otro fallo importante es el de la Sentencia del 30 de junio de 2005 a través del cual se desató el recurso de apelación interpuesto contra la sentencia proferida el 27 de junio de 2003 contra el Instituto Municipal de Reforma Urbana, entidad que declaró insubsistente a una persona que desempeñaba el cargo de Profesional Universitario en provisionalidad. En dicho fallo se reiteró que el pilar de la carrera administrativa está en el mérito y la capacidad de quien ha sido seleccionado, por lo que no hay lugar a la inscripción automática en el escalafón para obtener el ingreso a los cargos en carrera y es necesario cumplir con los requisitos y condiciones que exija la ley, tal como lo ordena el artículo 125 de la Constitución Política de Colombia de 1991. Advierte dicha decisión que solamente con el sometimiento a las etapas del concurso y la superación satisfactoria de todas ellas, se dan las condiciones para predicar los derechos que otorga la carrera administrativa y que "a su turno el retiro del servicio de un empleado que ostenta tal condición, está rodeado de plenas formalidades, pues, solamente mediante acto de insubsistencia, motivado en una calificación satisfactoria, puede dar lugar a la declaratoria de insubsistencia" (Sentencia del 30 de junio de 2005, párr. 15).

Por las anteriores consideraciones, no puede estar en igualdad de condiciones el empleado o servidor que ingresa al servicio sin preceder concurso de méritos y aquel que se somete a las etapas que conforman el proceso selectivo, si su designación entonces no es equiparable a la del 
escalafonado en la carrera. El retiro, por obvias razones, no puede ser de la misma forma y asimilar el fuero de estabilidad propia de los empleados de carrera administrativa a los nombramientos provisionales, so pretexto de la naturaleza del empleo, distorsiona el sistema del concurso de méritos y desconoce que la permanencia en los cargos de carrera operan exclusivamente cuando se ingrese al sistema mediante la superación de las etapas que comprende el proceso selectivo. Concluye el Consejo de Estado en esta decisión:

La situación del designado provisionalmente se asemeja a la de los designados para ocupar cargos de libre nombramiento y remoción, porque en ambos casos, el nombramiento se realiza en ejercicio de la facultad discrecional del nominador de escoger en beneficio del servicio a quien tenga las condiciones de idoneidad para desempeñar la función y el retiro, el cual a su vez esta precedido de razones objetivas plenamente justificadas en el interés general, que así mismo, la facultad discrecional de los empleados provisionales se impone al efectuar el nombramiento en tal carácter de provisionalidad, puesto que la transitoriedad de la designación mientras se realiza el proceso selectivo, autoriza a la administración a realizar el proceso selectivo, autoriza a la administración a realizar el nombramiento provisional. (Sentencia del 30 de junio de

2005, párr. 20-21)

\section{Balance del enfrentamiento judicial}

El enfrentamiento entre el Consejo de Estado y la Corte Constitucional se originó en la divergencia de conceptos jurídicos y del papel que ejerce cada uno de estos tribunales, habida cuenta que al primero le corresponde el estudio y fallo de las demandas administrativas más importantes que se ejercen en contra del Estado, por lo que realiza un estudio de fondo del objeto 
a tratar, y es al segundo a quien le corresponde salvaguardar la Constitución Política de Colombia de 1991, así como la garantía real y material de los derechos fundamentales de las personas, sin que estos queden expuestos en letra muerta.

Se puede evidenciar en las sentencias en cita de la Corte Constitucional que los empleados que se encuentran en provisionalidad y que han sido declarados insubsistentes sin que exista motivación del respectivo acto administrativo, han acudido al máximo tribunal para que le sean tutelados sus derechos fundamentales al debido proceso, a la estabilidad laboral, etc.. En la mayoría de casos la Corte ha amparado los derechos del empleado afectado y se ha ordenado al nominador o bien restituirlos a sus cargos o motivar el acto administrativo que declaró su insubsistencia, a sabiendas que en la misma Constitución Política se ha indicado el carácter general de la carrera administrativa sin que exista disposición alguna que regule la situación jurídica de los empleados nombrados en provisionalidad.

Así mismo, se evidencia en las decisiones adoptadas por el Consejo de Estado, luego de transcurrido el correspondiente proceso (contestación a la demanda, interposición de excepciones y práctica de pruebas), que no se puede equiparar el carácter de empleados en carrera administrativa a los nombrados en provisionalidad sin que haya superado el correspondiente proceso de selección, pues ello daría a entender una selección automática que no puede darse.

De lo anterior se colige que la cuestión de los empleados que laboran en provisionalidad es compleja, pues a cada tribunal le asisten razones jurídicas para fundamentar sus decisiones, puesto que el referido vacío normativo solo se decidirá en el momento en que se les otorgue el carácter de empleados en carrera administrativa o expresamente se les equipare a los empleados de libre nombramiento y remoción. Así mismo, la falta de disposición expresa con respecto al asunto ha ocasionado que la mayoría de empleados en provisionalidad transciendan en el tiempo. Ahora bien, 
pese a las razones válidas del Consejo de Estado, es posible afirmar que mientras se promulgue algún acto legislativo se deben proteger los derechos fundamentales invocados por los interesados, principalmente el derecho fundamental al debido proceso, de lo contrario se estaría desconociendo el Estado Social de Derecho.

Según Torres y Ruiz, La Corte Constitucional al establecer la motivación de los actos de insubsistencia o retiro de empleados que ocupan cargos en provisionalidad para brindarles a estos empleados una mayor garantía en el desempeño de sus funciones, además los beneficia con la posibilidad de acceder a la acción de tutela cuando estos empleados consideren que se les ha vulnerado sus derechos y que la tesis del Consejo de Estado, ha sido modificada en pro de los empleados provisionales, haciéndole exigible a la administración la motivación del acto administrativo por medio del cual se desvincula a un empleado que tiene esa calidad.

Es pertinente tener en cuenta que son muchos los empleados públicos que se encuentran a la expectativa de lo que sucederá con sus empleos, puesto que, a pesar de encontrarse vinculados a la administración pública por bastantes años, existe una norma de rango constitucional que amenaza con la continuidad de sus cargos., siendo este el tema central la situación de dicho grupo vulnerable protegido especialmente por el Estado. Por ende, también amenaza su estabilidad laboral, puesto que la permanencia en sus cargos solo podría derivarse de la selección en el sistema de méritos y no del tiempo que se encuentre vinculado al Estado en provisionalidad.

Ante esta situación se inició un movimiento conformado por las personas que se encontraban en dicha situación para que fuera tenido en cuenta, en los procesos de designación mediante concurso, el tiempo que habían laborado en las diferentes instituciones. Procedieron entonces a hacer gestiones para que en el Congreso de la República se votara a favor de un proyecto de acto legislativo (No. 1 de 2008) que modificaría el artículo 125 de la Constitución Política, de acuerdo 
con el cual se podría nombrar en propiedad a los empleados públicos que se encontraran ocupando cargos en provisionalidad. Específicamente se pretendía:

“La Comisión Nacional de Servicio Civil implementará los mecanismos necesarios para inscribir en carrera administrativa de manera extraordinaria y sin necesidad de concurso público a los servidores que a la fecha de publicación de la Ley 909 del 2004 estuviesen ocupando cargos de carrera vacantes de forma definitiva en calidad de provisionales o de encargados del sistema general de carrera siempre y cuando cumplieran las calidades y requisitos exigidos para su desempeño al momento de comenzar a ejércelo y que a la fecha de la inscripción extraordinaria continúen desempeñado dichos cargos de carrera”.

El proyecto de acto legislativo buscaba que los empleados que llevaran en provisionalidad de cinco a veinte años obtuvieran el beneficio de ser inscritos en el escalafón de carrera administrativa y que con ello se legalizara su situación jurídica. Para muchos de ellos se había presentado este problema por una falla en la administración y por la falta de disposiciones que regularan de fondo tal situación particular, habida cuenta que por la falta de precisión en el régimen jurídico se había asociado la forma de vinculación en provisionalidad a los empleos de carrera y a los de libre nombramiento. Por el contrario, consideraban que la provisionalidad no corresponde a ninguna de estas dos clases de vinculación a las entidades del Estado, lo que ha causado inseguridad jurídica, pero sobre todo el choque o confrontación entre las altas Cortes, que adoptan desde su punto de vista específico las correspondientes decisiones.

Lo anterior buscaba adicionar un parágrafo al artículo 125 de la Constitución Política de 1991 y dispondría que durante tres años contados a partir de la vigencia del acto legislativo, la Comisión Nacional del Servicio Civil implementaría los mecanismos necesarios para inscribir de manera extraordinaria y sin necesidad de concurso público a los servidores públicos que se 
encontraran en provisionalidad o encargo en un empleo por vacancia definitiva, siempre y cuando durante tres años o más hayan desempeñado cargos de carrera.

Dicha Acta de Conciliación al Proyecto de Ley 117 de 2008 fue objeto de objeciones presidenciales. En efecto, el Presidente de la República se opuso a los artículos 1, 4, 7, 8 y 9 del proyecto, cuyo contenido conviene citar en extenso para tener claro su alcance:

Artículo 1. Adiciónese el siguiente parágrafo nuevo, que será el $2^{\circ}$, al artículo $3^{\circ}$ de la Ley 909 de 2004 y modifíquese la nomenclatura quedando el actual parágrafo $2^{\circ}$ como parágrafo $1^{\circ}$ :

Parágrafo $2^{\mathbf{0}}$. Período de Transición. Los empleados que a la fecha de publicación de la Ley 909 de 2004, estuviesen ocupando cargos públicos vacantes de forma definitiva, en calidad de provisionales, del sistema general de carrera, y que a la entrada de la vigencia de la presente ley aun ocupen dichos cargos, no podrán ser separados de su cargo sino por las causales contenidas en el artículo 41 de la misma Ley. Mientras permanezcan en sus cargos su desempeño será evaluado anualmente, siguiendo el procedimiento que se establezca en el reglamento.

Los demás empleos serán provistos con las listas de elegibles resultantes de las convocatorias que adelanta la Comisión Nacional del Servicio Civil del sistema general de carrera, utilizándose también cuando se generen vacantes en cumplimiento del inciso anterior. Las listas de elegibles resultado de la Convocatoria número 001 de 2005 tendrán una vigencia de tres años.

Para las entidades y organismos del Estado cuya carrera sea vigilada y administrada por la Comisión Nacional del Servicio Civil, es un deber reportar las vacantes definitivas que 
deben ser provistas mediante concurso público, en las fechas que señale este organismo, su incumplimiento y el de las demás directrices e instructivos constituyen falta disciplinaria.

[...] Artículo $4^{\circ}$. Los servidores públicos que se encuentren ocupando cargos de vacancia definitiva, en calidad de provisionales, y con discapacidades (físico, mental, visual o auditivo) y les faltaren menos de tres (3) años para pensionarse contados a partir de la promulgación de la presente ley, tendrán derecho a los beneficios establecidos en el artículo $1^{\mathrm{o}}$ de esta ley para los trabajadores nombrados en provisionalidad.

[...] Artículo $7^{\mathbf{0}}$. Sistemas específicos y especiales de origen legal. Los empleados que a la fecha de publicación de la Ley 909 de 2004, estuviesen ocupando cargos públicos vacantes de forma definitiva, en calidad de provisionales, de los sistemas específicos y especiales de origen legal, con excepción del que rige para el personal docente, no podrán ser separados de su cargo sino por las causales enlistadas a continuación y siempre que los concursos públicos que estén adelantando se encuentren en etapa anterior a la publicación de la lista de elegibles.

a) Por declaratoria de insubsistencia del nombramiento en los empleos de libre nombramiento y remoción;

b) Por declaratoria de insubsistencia del nombramiento, como consecuencia del resultado no satisfactorio en la evaluación del desempeño laboral de un empleado de carrera administrativa,

c) Por renuncia regularmente aceptada,

d) Retiro por haber obtenido la pensión de jubilación o vejez;

e) Por invalidez absoluta; 
f) Por edad de retiro forzoso,

g) Por destitución, como consecuencia del proceso disciplinario;

h) Por declaratoria de vacancia del empleo en el caso de abandono del mismo;

i) Por revocatoria del nombramiento por no acreditar los requisitos para el desempeño del empleo, de conformidad con el artículo $5^{\circ}$ de la Ley 190 de 1995, y las normas que lo adicionen o modifiquen;

j) Por orden o decisión judicial;

k) Por supresión del empleo;

1) Por muerte;

m)Por las demás señaladas por la Constitución Política y la ley.

Mientras permanezcan en sus cargos su desempeño será evaluado anualmente, siguiendo el procedimiento que se establezca en los respectivos reglamentos de la entidad correspondiente.

Los demás empleos serán provistos con las listas de elegibles resultantes de las convocatorias que adelanten los respectivos organismos encargados para tal fin.

Para las entidades y organismos del Estado cuya carrera sea vigilada y administrada por la Comisión Nacional del Servicio Civil, es un deber reportar las vacantes definitivas que deben ser provistas mediante concurso público, en las fechas que señale este organismo, su incumplimiento y el de las demás directrices e instructivos constituyen falta disciplinaria.

Artículo 8. Modificar el parágrafo del artículo 4º de la Ley 1033 de 2006 el cual quedará así: 
Parágrafo. Periodo de Transición. Los empleados públicos civiles y no uniformados del sector Defensa, que a la fecha de publicación de la Ley 1033 de 2006, estuviesen ocupando cargos públicos en calidad de provisionales del sistema especial de carrera del

Sector Defensa, no podrán ser separados de su cargo sino por las causales de retiro previstas en el Decreto-ley 091 de 2007. Mientras permanezcan en sus cargos su desempeño será evaluado anualmente siguiendo el procedimiento establecido para los empleados pertenecientes al Sistema Especial de Carrera del Sector Defensa.

Los procesos de selección para proveer los demás empleos del Sistema Especial de Carrera del Sector Defensa serán desarrollados de conformidad con las disposiciones contenidas en el Decreto 091 de 2007 y las demás disposiciones que lo modifiquen o adicionen, y la convocatoria deberá efectuarse dentro de los tres años siguientes a la entrada en vigencia del citado decreto-ley.

Para las entidades y dependencias que integran el Sector Defensa, los nombramientos provisionales se continuarán rigiendo por lo dispuesto en el Decreto 091 de 2007 y las demás disposiciones que lo modifiquen o adicionen.

Artículo 9 ${ }^{\circ}$. Los servidores y empleados de la Fiscalía General de la Nación, que a la entrada en vigencia de la Ley 938 de 2004 "Estatuto Orgánico de la Fiscalía", estuviesen ocupando cargos de provisionalidad, no podrán ser separados del mismo sino por las causales de retiro previstas en el artículo 77 de la Ley 938 de 2004. Su evaluación se hará de acuerdo a los procedimientos establecidos para los empleados de Carrera. (Acta de Conciliación al Proyecto de Ley 117, 2008, Art. 1-9)

Consideró el Presidente de la República que dichos preceptos iban en contraposición de los artículos 125, 217, 218 253, 256, 268 y 279 de la Constitución y que también existía 
desconocimiento de sus artículos 13, 40-7 y 125, dado que las normas impugnadas atribuían un trato especial sin que existiera un fundamento constitucional y legal a un grupo minoritario que se encontraban en provisionalidad y que ahora se hallaban en vacancia definitiva. Esto equivaldría a un trato desigual que supondría una inscripción definitiva sin que exista mérito para ello, desconociendo el numeral 7 del artículo 40 de la Constitución de 1991 y el artículo 125 de la misma.

Así mismo, fue formulado en el año 2011 otro proyecto que planteaba el ingreso automático a la carrera administrativa, si el empleado vinculado en provisionalidad demostraba cinco años en el oficio y conocimiento de la entidad en donde laboraba, propuesta que favorecía en ese entonces a 120.000 empleados provisionales. Esta propuesta fue aprobada en la plenaria de la Cámara de Representantes al votar favorablemente la ponencia presentada por el congresista Humprey Roa. Dicha propuesta no fue acogida por la Comisión Nacional del Servicio Civil, considerando que contrariaba el derecho a la igualdad; en tanto que a la experiencia de los empleados provisionales les otorgaría un puntaje de 70 puntos, poniéndolos en alto grado de superioridad frente a los aspirantes que no pertenecía al sector público y que deseaban concursar.

Por otro lado, también existía ventaja para los empleos en encargo por el requisito de los tres años en servicio, así como la asignación de puntaje adicional por especialización (3 puntos), maestría (6 puntos) y por doctorado (10 puntos). Por esta razón, la Comisión Nacional del Servicio Civil se opuso rotundamente al considerar que se configuraría una flagrante violación al artículo 125 de la Constitución. 
En marzo del año 2012, la Corte Constitucional declaró inexequible este proyecto, que fuera aprobado en el mes de junio del año 2011, al considerar que el tiempo de experiencia y el conocimiento de la entidad eran un privilegio para los empleados vinculados en provisionalidad. Por lo tanto el, tribunal constitucional afirmó que dicha prerrogativa contravenía el espíritu y los principios de la Constitución Política de Colombia, en tanto que el artículo 125 de la Carta indica que la condición para ingresar o ascender a cargos del Estado se debe fincar simple y llanamente al concurso de méritos. Fue este entonces otro intento fallido, pues la Corte Constitucional nuevamente derribó otra tentativa de reforma.

Por otro lado, el Proyecto de Ley 054 de 2010 soportó varias críticas y oposiciones en lo que respecta a su contenido, pues con este se pretendía adicionar a la Ley 909 de 2004 una disposición del siguiente tenor:

Artículo $1^{\circ}$. Adiciónese el siguiente artículo 52A a la Ley 909 de 2004, Retén Social: Los servidores públicos que a la entrada en vigencia de la presente ley, se encuentren nombrados en provisionalidad dentro de las entidades u organismos a los cuales se les aplica el sistema de carrera general o los sistemas específicos y especiales, no podrán ser separados de su cargo, salvo por las causales contenidas en la respectiva ley de carrera, si cumplen algunas de las siguientes condiciones:

a) Ser Madre o Padre cabeza de familia sin alternativa económica.

b) Estar en condición de cualquier tipo de discapacidad.

c) Sufrir enfermedad que implique tratamiento continuo o de tipo terminal, mantendrán su vinculación laboral hasta la culminación del tratamiento respectivo o la muerte. 
d) Estar próximo a pensionarse, esto es que le falten tres años o menos para acceder al derecho a la pensión.

e) Encontrarse laborando en zonas de difícil acceso y/o en situación crítica de inseguridad. Artículo $2^{\circ}$. Para efectos de aplicación de la presente ley se entenderán como zonas de difícil acceso y zonas en situación crítica de inseguridad:

Zonas de difícil acceso: Son aquellas que por sus características geográficas, deficiencia de vías y medios de transporte, exigen un esfuerzo físico o económico fuera de lo ordinario, para permanencia o movilización del servidor público.

Zonas en situación crítica de inseguridad: Son aquellas donde se presenta alteración del orden público que afecta el normal desarrollo de las actividades laborales.

Parágrafo: Tanto las zonas de difícil acceso como la de situación crítica de inseguridad respectivamente, deberán ser certificadas por la autoridad municipal competente para efectos de la aplicación de la presente ley. (Proyecto de Ley 054, 2010, Art. 1).

Estas disposiciones tenían por finalidad crear ciertos beneficios para los empleados vinculados en provisionalidad al Estado. Con todo, nuevamente bajo el argumento del desconocimiento al artículo 125 de la Constitución, el 15 de febrero de 2012 el Gobierno Nacional objetó este proyecto de ley considerando que desconocía además del sistema de méritos el derecho a la igualdad y que era una forma de abrirle paso a la vinculación automática a la carrera administrativa. Al objetar el proyecto el Gobierno Nacional consideró:

No es procedente establecer privilegios a favor de los empleados provisionales, independientemente de su condición o ventajas, toda vez que deben participar en igualdad de condiciones con todos los ciudadanos que cumplan con requisitos para aspirar u ocupar 
un cargo público, salvo los discapacitados y enfermos crónicos. (Ley 054, 2010, numeral 2.3)

Como corolario de lo anterior, la Corte Constitucional resolvió devolver el expediente legislativo al Congreso de la República, para que subsanara lo que consideró era un vicio de trámite por no agotar el requisito de la votación nominal y pública del informe de objeciones gubernamentales en plenarias del Senado de la República y de la Cámara de Representantes, por lo que otorgó un plazo prudencial para subsanarlo. Posteriormente debía devolverse el expediente legislativo para que el Tribunal Constitucional pudiera pronunciarse sobre las objeciones de inconstitucionalidad planteadas por el Gobierno Nacional.

En su oportunidad el Congreso de la República argumentó que la finalidad del proyecto de ley era la protección especial a la familia, la salud, la estabilidad económica y la protección al núcleo familiar y que no se trataba de una vinculación al sistema de carrera administrativa, pues se trataba de proteger los grupos vulnerables, con sustento en el Estado Social de Derecho.

Al contenido del proyecto le dieron un término para corregir el error de procedimiento y al artículo 241 de la Constitución Política de Colombia del voto en su parágrafo y la ley 5 de 1992 artículo 202, para que luego de enviarlo a la Corte Constitucional se determinara su exequibilidad por omitir el trámite nominal y publica del informe de objeciones gubernamentales en sesiones de plenarias y cámaras de representantes. Finalmente, el proyecto fue aprobado en la plenaria de la Cámara de Representantes con el epígrafe: "por medio del cual se implementa el retén social, que garantiza la estabilidad laboral a grupos vulnerables", y con la finalidad de proteger a los grupos y personas vulnerables y no de vulnerar las normas de la carrera administrativa. 
El acto legislativo fue demandado ante la Corte Constitucional la cual determinó declararse inhibida para proferir un pronunciamiento de fondo indicando que "En ausencia de los requisito mínimos requeridos para la acción pública de inconstitucionalidad en relación con el exceso de competencia del Congreso para reformar la Constitución, la Corte se declaró inhibida para pronunciarse de fondo sobre la demanda".

\section{Consideraciones finales}

Se observa de esta primera parte del trabajo de investigación que el sistema de méritos para el ingreso a los cargos públicos se ha venido construyendo desde hace varios años, pues se introdujo tímidamente en la Constitución de 1886 con el fin de limitar la facultad nominadora del Presidente de la República, los gobernadores y los alcaldes, buscando sobre todo limitar las vinculaciones de libre nombramiento y remoción. Si bien este propósito se reafirmó en la Reforma Constitucional de 1936, no fue sino en la Constitución de 1991 en donde se estableció que la carrera administrativa sería la regla general para vincular personal al Estado. No obstante, al no haberse surtido el correspondiente concurso en varias entidades, estas tuvieron que acceder a la figura de la provisionalidad; para de esta manera garantizar la prestación del servicio público. La excepción se ha convertido prácticamente en la regla general, por lo cual dicha situación ha generado controversias jurídicas con el fin de establecer si los actos administrativos que declaran las insubsistencias deben ser motivados o no por los nominadores. Frente a las acciones judiciales iniciadas por los afectados, el Consejo de Estado ha concluido que los empleados provisionales no pueden adquirir las mismas prerrogativas que los empleados que han superado el concurso de 
méritos, mientras que la Corte Constitucional ha buscado garantizar los derechos fundamentales de los empleados vinculados en provisionalidad.

También se han surtido varios intentos de reforma constitucional y legislativa que tratan de encontrar una solución de fondo a una problemática que ha sido provocada por el mismo Estado, dado que no ha surtido el concurso de méritos para proveer las vacantes en las diversas instituciones. Estas intenciones han sido fallidas, pues se ha considerado en varios sectores que debe imperar la norma constitucional que ordena el ejercicio de la carrera administrativa como forma de proveer los cargos de Estado para garantizar la adecuada prestación de los servidores públicos

Es claro además que los empleados vinculados excepcionalmente han adquirido los mecanismos internos suministrados por el mismo Estado para mantenerse en dichos cargos, en el caso de las mujeres cabeza de familia se han dado varios intentos legislativos u otras garantías especiales y/o adicionales de tipo legal y jurisprudencial, como referente se encuentra la ley 790 de 2002 reglamentada por el decreto 190 de 2003, especialmente en su artículo 12, el cual indicó que en el cumplimiento del Programa de Renovación para la Administración Pública no podrían ser retiradas de sus cargos las madres cabeza de familia sin alternativa económica entre otros grupos de condición de vulnerabilidad.

Dicha disposición fue objeto de estudio por parte de la Corte Constitucional a través de diferentes sentencias entre ellas la SU- 388 y SU- 389 de 2005 en donde concluyeron que en los proceso de reestructuración que realicen en su interior las entidades públicas deben garantizarse los derechos fundamentales a aquellas personas con protección constitucional especial.

Se encuentra también la acción de tutela como mecanismo transitorio para proteger sus derechos fundamentales Estado; llevándola a garantizarle a toda persona, en sede de revisión de 
tutela, el ejercicio del recurso judicial efectivo consagrado en el artículo $2^{\circ}$ del Pacto Internacional de Derechos Civiles y Políticos y en el artículo 25 de la Convención Americana sobre Derechos Humanos, haciendo en este caso obligatorio la motivación del acto administrativo que declara la insubsistencia en ejercicio del derecho al Debido Proceso al Acceso a la Administración de Justicia entre otros derechos para efectos de que los actos administrativos puedan ser analizados en concreto por el juez natural.

Otro mecanismo es la acción de nulidad y restablecimiento de derecho a donde es posible acudir siempre y cuando como se indicó anteriormente el acto administrativo que declara la insubsistencia se encuentre debidamente motivado y se finque en argumentos estrictos y puntuales como los son la provisión definitiva del cargo una vez realizado el respectivo concurso de méritos; la calificación insatisfactoria del funcionario, la imposición de sanciones disciplinarias y "otra razón especifica atinente al servicio que está prestando". En dicha acción se pretende como primera medida declarar la nulidad del acto administrativo ordena la insubsistencia del empleado vinculado al Estado en provisionalidad y como restablecimiento del derecho, el reintegro al cargo del cual fue relevado y/o el pago de indemnizaciones en ocasión a los salarios dejados de percibir, las prestaciones sociales y otras afectaciones que pueden ser reconocidas siempre y cuando sean probadas dentro del proceso administrativo.

La Corte Constitucional en sentencia de unificación 917 de $2010^{8}$ determinó unos criterios para ser aplicados ante la jurisdicción de lo contencioso administrativo y de esta manera hacer efectivos los derechos al Debido Proceso y el Acceso a la Administración de Justicia de los demandantes aplicables en los siguientes eventos:

\footnotetext{
${ }^{8}$ Sentencia de unificación 917 de 2010, Corte Constitucional, M.P Jorge Ivan Palacio Palacio.
} 
“(...) 1. Proceso ordinario en que unos fallos de instancia ha sido conforme a la jurisprudencia trazada por la Corte Constitucional; el juez de tutela en este caso debe dejar sin efecto la sentencia contraria al procedente y, en su lugar, confirmar el fallo de instancia que se ajusta a la jurisprudencia constitucional.

2. Cuando ninguna decisión de instancia se ajusta a la jurisprudencia constitucional y no es posible entonces dejar ninguna en firme; caso en el cual deberá el juez de tutela dejar sin efecto el fallo de última instancia y ordenar que se dicte uno nuevo ajustado al precedente constitucional.

3. Cuando en oportunidades precedentes se ha ordenado dictar un nuevo fallo pero el juez de instancia se niega a proferirlo o lo hace en contravía a las normas fijadas en la jurisprudencia constitucional, a sabiendas de que la protección efectiva de los derechos fundamentales resultara afectada: En estos casos el juez de tutela, y muy especialmente la Corte Constitucional, debe tomar directamente las medidas necesarias, debiendo incluso dictar sentencia sustitutiva o de reemplazo, toda vez que no habría otra alternativa para garantizar la real y efectiva protección de los derechos fundamentales de los demandante y con ello el derecho de acceso a la administración de justicia en condiciones de igualdad”.(Caicedo 2014).

Como se observa internamente y siendo consciente el Estado a través de sus poderes públicos (legislativo, ejecutivo y judicial) de la obligación de salvaguardar a grupos con protección constitucional especial, ha adoptado una serie de medidas legislativas, jurisprudenciales tendientes a proteger a dichos grupos vulnerables en este caso las mujeres cabeza de familia, inclusive anteponiéndose sobre otras disposiciones de carácter constitucional como el sistema de méritos en donde a pesar de que no se ha dado una solución definitiva a su situación sí ha acudido a otras medidas positivas reconociéndoles una estabilidad relativa. 
Ahora bien, otro de los mecanismos pero de orden internacional que tienen las mujeres y hombres cabeza de familia por ende su núcleo familiar (niños, tercera edad, personas discapacitados) y que hasta el momento no ha sido ejercido en tanto que no se ha decidido de fondo el problema por parte del Estado colombiano, es el acudir ante la Comisión Interamericana de Derechos Humanos órgano judicial de los Estados Americanos la cual tiene como misión aplicar e interpretar la CIDH y otros tratados a los cuales se somete al sistema de protección de derechos humanos, más aun cuando no solo existe una afectación a los derechos de la mujer sino también a los niños, a las personas discapacitadas y de la tercera edad entre otros.

El derecho internacional ha evolucionado ostensiblemente en tanto que antes se veía lejano para cualquier persona o grupo acceder a aquellas acciones que permiten el conocimiento y pronunciamiento de un caso en concreto en el orden externo a su Estado, sin embargo se han determinado los medios idóneos y efectivos para reclamar la vulneración a derechos fundamentales y de esta manera materializar el acceso a la justicia y a la tutela efectiva para lo que nos atañe de derechos fundamentales de carácter económico, social, individual y colectivo.

El Sistema Interamericano ha implementado medidas para que cualquier persona pueda acceder a estas acciones como por ejemplo el suministrar asesoría y asistencia jurídica gratuita de profesionales expertos en derecho internacional. La Comisión Interamericana de Derechos Humanos (2007 OEA), indicó que es un derecho humano el obtener las garantías que permitan alcanzar decisiones justas y que las garantías mínimas deben respetarse en el procedimiento administrativo y en cualquier otro procedimiento cuya decisión puede afectar los derechos a las personas. (p.24). 
Indica además que los derechos sociales son los derechos más expuestos a la arbitrariedad de los órganos administrativos pues suele ser el margen de mayor discrecionalidad del Estado, es así como el Sistema Interamericano de Derechos Humanos se ha pronunciado en varias oportunidades de la necesidad de limitar y controlar la discrecionalidad del Estado, una de esas decisiones es el caso Baena Ricardo en donde la Corte Interamericana indicó:

[ Que].. En cualquier materia, inclusive en la laboral y administrativa, la discrecionalidad de la administración tiene límites infranqueables, siendo uno de ellos el respeto de los derechos humanos. Es importante que la actuación de la administración se encuentre regulada, y ésta no puede invocar el orden público para reducir las garantías de los administrados.

[Que]...El SIDH ha subrayado la necesidad de regular y restringir la discrecionalidad estatal. Así, la Corte y la CIDH han establecido que la labor de la Administración posee límites concretos y que entre ellos se encuentra el respeto de los derechos humanos. En este punto, en casos que involucran a sectores especialmente vulnerables, la CIDH ha identificado la necesidad de trazar vínculos entre los alcances del debido proceso legal administrativo y la efectiva vigencia de la prohibición de discriminación.

Lo anterior para indicar que en el evento en que las mujeres cabeza de familia vinculadas en provisionalidad al Estado hace varios años, sean declaradas insubsistentes además de la acción de tutela y la acción ordinaria puede acudir luego de agotadas las acciones internas, al Sistema Interamericano de Derechos Humanos para que su caso en concreto sea revisado, en tanto que como se ha indicado en varias oportunidades en el discurrir del trabajo de investigación sería este un daño antijurídico provocado por el Estado en el grado de omisión al no surtir como lo ordena la Constitución los cargos luego de superado el concurso de méritos. 
La CIDH tiene dos funciones, una consultiva y otra contenciosa. La primera tiene la finalidad emitir opiniones sobre la interpretación y alcance del Pacto de San José de Costa Rica o de otras normas de derechos humanos que se encuentran en los instrumentos internacionales cualquier Estado miembro puede consultar a la corte, pedir opiniones sobre la compatibilidad de su legislación interna.

La segunda, una función contenciosa en donde la CIDH conocer de casos en contra de los Estados y los juzga si estos han violado alguna disposición de la Convención Interamericana de Derechos Humanos, sin embargo para acceder a dicha posibilidad es necesario que el Estado demandado haya ratificado la Convención Americana sobre Derechos Humanos y que haya hecho una declaración especial de aceptación de la competencia contenciosa.

Como se indicó en su momento agotados los requisitos, es decir los correspondientes procedimientos, especialmente los recursos internos del Estado, de considerar la Corte que el Estado ha violado alguno de los derechos y libertades protegidos en la Convención Interamericana sobre de Derechos Humanos resuelve que se le garantice al lesionado el derecho alegado, que se reparen las consecuencias de la situación que conllevó a la vulneración y se establece el pago de una indemnización justa.

Ahora bien, la Convención Interamericana de Derechos Humanos (Pacto de San José de Costa Rica), expedido del 7 al 22 de noviembre de 1969, establece en la Parte I Capítulo I establece “(Que) Los Estados Partes en esta convención se comprometen a respetar los derechos y libertades reconocidos en ella y a garantizar su libre y pleno ejercicio a toda persona que esté sujeta a su jurisdicción, sin discriminación alguna por motivos de raza, color, sexo idioma, opiniones políticas o de cualquier otra índole, origen nacional o social, posición económica, nacimiento o cualquier otra condición social“. 
Se protege en dicha convención al niño indicando, que tiene derecho a las medidas de protección que su condición de menor requieren por parte de su familia, la sociedad y el Estado. En este caso con la declaratoria de insubsistencia de mujeres y hombres cabeza de familia se desconocerían varios derechos humanos del núcleo familiar, especialmente a los niños por lo que el presente trabajo de investigación pretende aportar ideas para que no se causen perjuicios a un grupo importante de personas en ocasión a un daño que no tienen por qué soportar en tanto que a pesar de que el concurso de méritos se estableció como un principio constitucional, este no ha sido cumplido por el mismo Estado (Comisión Nacional del Servicio Civil)

En el caso en concertó es viable para las mujeres y hombres cabeza de familia acudir a la comisión Interamericana de Derechos Humanos bien sea en su función consultiva e interpretativa para que se pronuncie mediante concepto de la situación planteada o en la función contenciosa en donde si se produciría una decisión de fondo y unas consecuencias sancionatorias y pecuniarias que debería asumir eventualmente el Estado colombiano. 


\section{Parte II. Vinculación excepcional al estado de la mujer y hombre cabeza de familia}

En la segunda parte de esta investigación se analizarán las garantías que el Estado debe reconocer a las mujeres y hombres cabeza de familia y su núcleo familiar, de manera que se realizará un estudio de los tratados internacionales que las contempla, las normas constitucionales y legales que las ratifican y la evolución jurisprudencial en la materia. Todo esto para determinar si existe una vulneración masiva de derechos fundamentales en el caso de las mujeres y hombres cabeza de familia que, estando vinculadas laboralmente al Estado en provisionalidad, pudieran ser declarados insubsistentes al no haber superado el concurso de méritos. Finalmente, con base en este análisis se realiza un diagnóstico general de la situación, formulando algunas conclusiones y sugerencias.

\section{Capítulo 3. La mujer y el hombre cabeza de familia en Colombia}

En este tercer capítulo se analiza el argumento jurídico que le atribuye al Estado la obligación de proteger a la mujer y por ende al hombre en ejercicio del derecho a la igualdad de género. Para ello se abordan los diferentes tratados internacionales que conforman el andamiaje jurídico construido para evitar la discriminación de las mujeres, especialmente de aquellas que se han visto obligadas a asumir el rol de madres cabeza de familia, en donde no solo se ven avocadas en muchas

ocasiones a asumir la responsabilidad frente a la manutención de sus hijos, sino también la manutención de sus padres o familiares que soportan alguna enfermedad o discapacidad grave. 


\section{La protección a la mujer}

Para emprender el tema de la protección a la mujer es indispensable establecer el concepto de género, Montezuma (2017) en su trabajo de investigación titulado La justicia y su poder, los (as) jueces (as)y sus palabras. Estudio de género desde la región, indicó que según Isabel Cristina Jaramillo el género se define como "aquellas características que socialmente se atribuyen a personas de uno y otro sexo" (Jaramillo, 2000, págs., 29 y 32). Continuó indicando Montezuma (2017) que la opresión y subordinación de las mujeres apunta hacia la existencia de un poder de los varones sobre el colectivo femenino el cual ha concebido una desigualdad entre sexos debido al concepto de autoridad, tradición la costumbre.

Es decir que la subordinación y la desigualdad de la mujer frente al hombre data de mucho tiempo atrás, en donde debido al modelo patriarcal se creó una marcada desventaja de las mismas que ha sido aceptada por la sociedad a través de la historia, sin embargo fue con la declaración de los derechos de la mujer y de la ciudadana proclamada en 1971 por Olymple de Gouges en Francia, que se empezó a reconocer la igualdad entre hombres y mujeres (Montezuma, 2017, p.32)

Por otro lado, Valdés (2009) refiere que [a] partir de la constitución de 1991 han surgido en el ámbito de las decisiones judiciales de contenido laboral repetidas situaciones de conflicto, que develan concepciones diferentes en cuanto al verdadero sentido y contenido del elemento tutelar propio del derecho al trabajo, que esa circunstancia, que se ha traducido claramente en una desorientación sobre la real comprensión que deben tener las leyes sociales y que, a su vez, se concreta en una profunda afectación de la seguridad jurídica. (P.18) 
Una de estas situaciones y que le concierne al presente trabajo de investigación es la protección jurídica de la mujer, la cual deviene de las diferentes políticas sociales, de carácter nacional e internacional, que buscan no solo la igualdad de género sino además la participación masiva de la mujer en los diferentes ámbitos de la vida social, como el laboral, el político, el académico, entre otros.

La Asamblea General de las Naciones Unidas el 18 de diciembre de 1979 aprobó la Convención sobre la eliminación de todas las formas de discriminación contra la mujer, la cual entró en vigencia como tratado internacional el 3 de septiembre de 1981 y fue ratificado por veinte países. En esta convención se indicó que teniendo en cuenta que la Carta de las Naciones Unidas tiene como derrotero la garantía de los derechos fundamentales, en la dignidad y el valor de la persona humana, y que hombres y mujeres poseen los mismos de derechos, al tiempo que reafirma el principio de la no discriminación y reitera la proclamación del principio que establece que todos los seres humanos nacen libres e iguales en dignidad y gozan de derechos económicos, sociales, civiles y políticos.

Por su parte, el Sistema de Naciones Unidas (2010) en su publicación realizada en la misma anualidad, estableció:

[Que] los Estados Partes condenan la discriminación contra la mujer en todas sus formas, convienen en seguir, por todos los medios apropiados y sin dilaciones, una política encaminada a eliminar la discriminación contra la mujer. Para lograr este objetivo se proponen varias medidas, como consagrar en los constituciones nacionales y en cualquier otra legislación apropiada el principio de la igualdad del hombre y de la mujer y asegurar la realización práctica de ese principio; adoptar medidas adecuadas con las sanciones correspondientes, que prohíban toda discriminación contra la mujer; establecer la protección jurídica de los derechos de la mujer sobre una base de igualdad con los del 
hombre; abstenerse de incurrir en todo acto o práctica de discriminación contra la mujer; tomar todas las medidas apropiadas para eliminar la discriminación contra la mujer practicada por cualesquiera personas, organizaciones o empresas; y adoptar todas las medidas adecuadas, incluso de carácter legislativo, para modificar o derogar leyes, reglamentos, usos y prácticas que constituyan discriminación contra la mujer. (Art. 2)

En particular, en este mismo documento el Sistema de Naciones Unidas (2010) dispuso que "los Estados Partes adoptarán todas las medidas apropiadas para eliminar la discriminación contra la mujer en la esfera del empleo a fin de asegurar a la mujer, en condiciones de igualdad con los hombres, los mismos derechos" (Art. 10). Entre estos están el derecho a las mismas oportunidades de empleo, inclusive a la aplicación de los mismos criterios de selección en cuestiones de empleo; el derecho a elegir libremente profesión y empleo, el derecho al ascenso, a la estabilidad en el empleo y a todas las prestaciones y otras condiciones de servicio, y el derecho a la formación profesional, el derecho a igual remuneración, inclusive prestaciones, y a igualdad de trato con respecto a un trabajo de igual valor y el derecho a la seguridad social, en particular en casos de jubilación. Así mismo el Sistema de Naciones Unidas (2010) establece:

A fin de impedir la discriminación contra la mujer por razones de matrimonio o maternidad y asegurar la efectividad de su derecho a trabajar, los Estados Partes tomarán medidas adecuadas para: prohibir, bajo pena de sanciones, el despido por motivo de embarazo o licencia de maternidad y la discriminación en los despidos sobre la base del estado civil; para implantar la licencia de maternidad; para alentar el suministro de los servicios sociales de apoyo necesarios para permitir que los padres combinen las obligaciones para con la familia con las responsabilidades del trabajo y la participación en la vida pública, y para 
prestar protección especial a la mujer durante el embarazo en los tipos de trabajos que se haya probado puedan resultar perjudiciales para ella. (Art. 11)

La Convención sobre la eliminación de todas las formas de discriminación contra la mujer no solo le exige a los Estados Parte la implementación de medidas de índole legislativo, sino el ejercicio activo en la protección de los derechos de la mujer y, por ende, de los de su núcleo familiar. Es por ello que varios países ratificaron la convención implementando medidas para erradicar la discriminación en los ámbitos político, social, laboral, etc.

Lo anterior permite indicar que las mujeres son titulares de derechos especiales, pues además del reconocimiento hecho por el derecho internacional, los Estados han tratado de adoptar otras medidas tendientes a buscar el trato igualitario para la mujer, en pro de una vida libre de violencia, y para que vivan sin discriminación alguna, ejerciendo así el derecho a participar en igualdad de condiciones que el hombre en los diversos ámbitos de la vida social y cultural.

En Argentina por ejemplo según Birgin (2000) [La] ley general reguladora del trabajo dependiente (LCT) incluye normas de excepción para la mujer conforme a su sexo, estado civil y maternidad remitiéndose la norma (“Trabajo de mujeres”, Título VII) directamente a la protección de la maternidad, allí se fija el plazo obligatorio de noventa días, la empleada tiene la obligación de comunicar su estado de embarazo al empleador, se garantiza el derecho a la estabilidad en el empleo desde el momento de gestación (carácter de derecho adquirido) y durante la licencia obligatoria, se prohíbe el despido por causa de matrimonio y la ley autoriza un descanso diario de dos turnos de media hora para la lactancia y habilita un lugar para salas maternales y guarderías para niños cuyo límite de edad determine la regulación de la norma (artículo 179, según Ley 21.297). (p.5 y 6). 
En el caso de Colombia, el Estado debe adoptar medidas legislativas, en las cuales se abstenga de expedir normas incompatibles con el bienestar de la mujer, y que a través de ellas también cree programas y políticas específicas, contando así con los mecanismos necesarios para efectivizar los derechos de la mujer.

El contenido de la convención fue implementado en la legislación colombiana con la promulgación de la Ley 823 de 2003, la cual tiene por objeto "establecer el marco institucional y orientar las políticas y acciones por parte del Gobierno para garantizar la equidad y la igualdad de oportunidades de las mujeres, en los ámbitos público y privado” (Art. 1).

Ahora bien, desde la entrada en vigor de la Constitución de 1991 se estableció, en el marco del modelo del Estado Social de Derecho, la protección especial a las mujeres en donde se parte de la realidad de que efectivamente existe una desventaja de la misma frente a la sociedad. Con ello se busca el reconocimiento jurídico, real y efectivo de los derechos y de la igualdad de oportunidades para las mujeres. Entre estos derechos se encuentran los de índole laboral, razón por la cual el Estado está obligado a garantizarles a las personas y en este caso a las mujeres el derecho al trabajo, a la estabilidad, y al mínimo vital para ellas y su núcleo familiar.

Con lo anterior se reitera además que el gobierno debe crear e implementar políticas orientadas a proteger a las mujeres cabeza de familia según lo preceptuado en la Constitución Política de Colombia de 1991 y debe, por el contrario, evitar que se propicie la inestabilidad económica de ella y su núcleo familiar. Conviene recordar el tenor literal del artículo 43 de la Constitución, que dispone lo siguiente:

La mujer y el hombre tienen iguales derechos y oportunidades. La mujer no puede ser sometida a ninguna clase de discriminación, que durante el embarazo y después del parto gozará de especial asistencia y protección del Estado, y recibirá de este subsidio alimentario 
si entonces estuviere desempleada o desamparada. El Estado apoyará de manera especial a la mujer cabeza de familia. (Constitución Política de Colombia, 1991,

Art. 43)

\section{Estudio constitucional, legal y jurisprudencial respecto de los derechos de las mujeres cabeza de familia}

Una vez realizada esta introducción al tema, en donde se trajo a colación el fundamento principal que tienen los Estados para implementar las políticas que protejan a las mujeres de la discriminación partiéndose de que efectivamente existe una desventaja de la misma frente al Estado , en especial a aquellas mujeres que adicionalmente sostienen la condición de ser madres cabeza de familia, a continuación se procede a realizar el estudio constitucional, legal y jurisprudencial del objeto de estudio planteado.

\section{Fundamento constitucional y legal}

El bloque de constitucionalidad es aquel conjunto de normas y principios que aunque no aparecen explícitamente incorporados en una Constitución son utilizados como parámetros para el control de constitucionalidad de las leyes (Arango, 2004). En Colombia el término de bloque de constitucionalidad empezó a ser utilizado por la Corte Constitucional desde el año de 1995.

En la Constitución de 1991 se definieron en seis de sus artículos los parámetros para adoptar normas internacionales en el ámbito interno: en el artículo 9 se reconoce que las relaciones internacionales del Estado se fundamentan en la soberanía nacional y que los principios del derecho internacional son adoptado por Colombia; en el artículo 93 se 
establece que los tratados y convenios internacionales ratificados por el congreso y que se reconocen los derechos humanos no pueden ser limitados en los estados de excepción prevaleciendo en el orden interno; el artículo 94 indica que la enunciación de los derechos y garantías contenidos en la Constitución y en los convenios internacionales, no deben ser entendidos como la negación de otros, pues son inherentes al ser humano; a su turno, el artículo 214 ordena que al regularse los estados de excepción, no pueden suspenderse los derechos humanos, ni las libertades fundamentales y que en todo caso se respetaran las reglas del derecho internacional humanitario; por su parte, el artículo 53 preceptúa que los convenios internacionales de trabajo debidamente ratificados hacen parte de la legislación interna, mientras que el artículo 102 indica que los limites señalados en la forma prevista por la Constitución, sólo podrán modificarse en virtud de tratados aprobados por el congreso, debidamente ratificados por el Presidente de la República.

(Arango, 2004, pp. 80-81)

Ahora bien, respecto de la mujer se reconocieron derechos de especial protección. Entre ellos están los relacionados con la mujer embarazada, en conjunto con las disposiciones del derecho internacional de los derechos humanos que fueron incluidas en el bloque de constitucional. La Corte Constitucional, en Sentencia T-662 de 1997 (MP Alejandro Martínez Caballero) y en la Sentencia T-270 de 1997 (MP Alejandro Martínez Caballero) indicó que la mujer y su hijo gozan de especial protección por parte del Estado, como lo indica el artículo 43 de la Constitución Política de Colombia así como otros tratados internacionales ratificados por Colombia.

Estos son los fundamentos de Derecho internacional de los derechos humanos que sirven de base para entender el alcance de las normas que a nivel interno establecen la protección especial para las mujeres, algunas de las cuales se presentan a continuación. 
- Ley 51 de 1981

Con la Ley 51 de 1981 se aprobó la Convención sobre la eliminación de todas las formas de discriminación contra la mujer, la cual había sido adoptada por la Asamblea General de las Naciones Unidas el 18 de diciembre de 1979 y firmada en Copenhague el 17 de julio de 1980. En esta ley se establece una serie de medidas para evitar la discriminación de la mujer, no solo frente a la condición de los hombres sino además garantizarles los derechos que pregonan en nuestro Estado Social de Derecho.

Allí se compromete el Estado colombiano a adoptar todas las medidas apropiadas para garantizarles el ejercicio y el goce de derechos humanos y libertados fundamentales en las esferas política, social, económica y cultural; así como a adoptar medidas especiales encaminadas a la protección de la maternidad. Esto último con el propósito de modificar los patrones socioculturales de las conductas de hombres y mujeres, en busca de la erradicación de prejuicios por género, y para garantizar que la educación familiar incluya la comprensión adecuada de la maternidad como función social y que el derecho a la igualdad se encuentre en la esfera de la educación. Además de la implementación de medidas para eliminar la discriminación de la mujer en materia de empleo, entre otras.

- Ley 82 de 1993

A su turno, la Ley 82 de 1993 dispone que "la familia es núcleo fundamental e institución básica de la sociedad, se constituye por vínculos naturales o jurídicos, por la decisión libre de un hombre y una mujer de contraer matrimonio o por voluntad responsable de conformarla" (Art.

1). 
En esta ley se trajo por primera vez en Colombia el concepto de "jefatura femenina de hogar" (Ley 82, 1993, Art. 2), que fue modificado y ampliado posteriormente por la Ley 1232 de 2008, en los siguientes términos:

Para los efectos de la presente ley, la Jefatura Femenina de Hogar, es una categoría social de los hogares, derivada de los cambios sociodemográficos, económicos, culturales y de las relaciones de género que se han producido en la estructura familiar, en las subjetividades, representaciones e identidades de las mujeres que redefinen su posición y condición en los procesos de reproducción y producción social, que es objeto de políticas públicas en las que participan instituciones estatales, privadas y sectores de la sociedad civil.

En concordancia con lo anterior, es Mujer Cabeza de Familia, quien siendo soltera o casada, ejerce la jefatura femenina de hogar y tiene bajo su cargo, afectiva, económica o socialmente, en forma permanente, hijos menores propios u otras personas incapaces o incapacitadas para trabajar, ya sea por ausencia permanente o incapacidad física, sensorial, síquica o moral del cónyuge o compañero permanente o deficiencia sustancial de ayuda de los demás miembros del núcleo familiar. (Ley 82, 1993, Art. 2)

Se produce así una ampliación del concepto, pues anteriormente se hablaba de la mujer madre cabeza de familia y ahora se define como mujer cabeza de familia, en tanto que no solo puede tener bajo su responsabilidad sus hijos menores sino también familiares con discapacidad o sus padres, que por lo general se catalogan como adultos mayores.

Es preciso resaltar que en esta legislación se hace mención a la protección especial a la mujer, a la definición de un reglamento para garantizar el ingreso al sistema de seguridad social, al apoyo en materia educativa y al fomento para el desarrollo empresarial; a su vez, en materia cultural se 
garantiza que el Gobierno Nacional, en los departamentos y municipios, establecerá en favor de las mujeres y de quienes de ellas dependa el acceso preferencial a los auxilios educativos y servicios básicos de textos; así como apoyo educativo a las entidades de economía solidaria integradas en su mayoría por mujeres cabeza de familia.

Adicionalmente, se establece la implementación de incentivos especiales para el sector privado que propugne por el desarrollo de programas especiales de salud, educación, vivienda, seguridad social, crédito y empleo para las mujeres cabeza de familia. Se introdujo el factor de ponderación que beneficia las propuestas de la mujer cabeza de familia o de las personas jurídicas en las cuales ella participe mayoritariamente, además del apoyo a las organizaciones sociales de mujeres para el acceso a vivienda, entre otras medidas.

En este sentido, a la mujer cabeza de familia se le ha atribuido el rol de mujer encargada del hogar, por lo que el Constituyente de 1991 quiso equilibrar las cargas en el interior de la familia: uno de los roles que culturalmente se impuso a la mujer fue el de "encargada del hogar" como una consecuencia del ser "madre".

- Ley 581 de 2000

Cabe mencionar la Ley 581 de 2000, pues estableció que acciones afirmativas como las Leyes de Cuotas son necesarias para lograr la igualdad real y efectiva consagrada en el artículo 13 de la Constitución, de manera que puedan ser abolidas las situaciones de desventaja o marginalización en las que se encuentran ciertas personas o grupos. Es así como establecen un trato "desigual" para quienes son desiguales, con el fin de disminuir distancias económicas, culturales o sociales.

La finalidad de dicha ley es la de crear los mecanismos para que las autoridades, en cumplimiento de los mandatos constitucionales, le den a la mujer la efectiva participación a la que 
tiene derecho en todos los nieves de las ramas y demás órganos del poder público; allí se definió como máximo nivel decisorio "aquel que corresponde a quienes ejercen los cargos de mayor jerarquía en las entidades de las tres ramas del poder público, en los diferentes niveles, es decir el nacional, departamental, regional, provincial, distrital y municipal” (Ley 581, 2000, Art. 2).

Se definió también como de otros niveles decisorios "los cargos de libre nombramiento y remoción, de la rama ejecutiva, del personal administrativo de la rama legislativa y de los demás órganos del poder público" (Ley 581 de 2000, Art. 3), así como los de libre nombramiento y remoción de la rama judicial. La participación efectiva de la mujer en los niveles del poder público se garantiza por parte de las autoridades nominadoras estableciendo que "mínimo el treinta por ciento 30\% de los cargos de nivel decisorio deben ser desempeñados por mujeres y mínimo el treinta por ciento 30\% de los cargos de otros niveles decisorios" (Ley 581, 2000, Art. 4), serán también desempeñados por mujeres.

- Ley 823 de 2003

También está la Ley 823 de 2003 que "tiene por objeto determinar el marco institucional, así como orientar las políticas y acciones por parte del gobierno para garantizar la equidad y la igualdad de oportunidades en los ámbitos público y privado" (Art. 1), garantizando de esta manera el reconocimiento constitucional de la igualdad jurídica, real y efectiva de los derechos y oportunidades de mujeres y hombres en lo que concierne a la dignidad humana y a los principios en los acuerdos internacionales. Dispone así que la igualdad de oportunidades para las mujeres, especialmente para las niñas, es parte inalienable, imprescriptible e indivisible de los derechos humanos y libertades fundamentales.

- Ley 1257 de 2008 
Por otro lado, a través de la Ley 1257 de 2008 se adoptaron normas para garantizar a todas las mujeres una vida libre de violencia en el ámbito público y privado, el ejercicio de los derechos reconocidos en el ordenamiento jurídico nacional e internacional para el acceso a los procedimientos administrativos y judiciales para su protección y atención, así como la adopción de las políticas públicas para su materialización.

Se definió allí la violencia contra la mujer como "cualquier acción u omisión, que le cause muerte, daño o sufrimiento físico, sexual, psicológico, económico o patrimonial por su condición de mujer, así como las amenazas de tales actos, la coacción o la privación arbitraria de la libertad" (Ley 1257, 2008, Art. 2); todo en aplicación a lo dispuesto en los Planes de Acción de las Conferencias de Viena, Cairo y Beijing. Asimismo, se definió como violencia económica a “cualquier acción u omisión orientada al abuso económico, al control abusivo de las finanzas recompensas o castigos monetarios a las mujeres por razón de su condición social, económica o política" (Ley 1257, 2008, Art. 2).

- $\quad$ Ley 1434 de 2011

La Ley 1434 de 2011 tuvo por finalidad "fomentar la participación de la mujer en el ejercicio legislativo y de control político mediante la creación de la Comisión legal para la equidad de la mujer en el Congreso de la República" (Art. 1). De esta manera se implementan las acciones necesarias para la consolidación de una política del Estado que permita mejorar la calidad de vida material e inmaterial de la mujer, erradicando cualquier forma de desigualdad y discriminación de las mujeres en ejercicio de sus derechos como ciudadana. Dicha comisión se compone de diecinueve (19) congresistas, diez (10) de la Cámara de Representantes y nueve (9) del Senado de la República. 
- Ley 1450 de 2011

La Ley 1450 de 2011 que expidió el Plan Nacional de Desarrollo, estableció en su artículo 177 que el Gobierno Nacional en cabeza de la Alta Consejería para la Equidad de la Mujer adoptará una Política Nacional de Equidad de Género con el fin de garantizar los derechos humanos de las mujeres y la igualdad de las mujeres. Uno de los ejes en el que actualmente se está trabajando en el marco de formulación de esta Política de Equidad para las mujeres, liderada por la Alta Consejería con la participación activa del Gobierno y de las organizaciones sociales, es el de participación política de las mujeres.

Dicha política le permitirá al Estado efectivizar planes que garanticen los derechos de las mujeres en situación de desplazamiento y el derecho de las mujeres a una vida libre de violencia, bajo la participación y coordinación de la Alta Consejería para la Equidad de la Mujer. Ahora bien, esta entidad que debe ser fortalecida institucional y presupuestalmente para el cumplimiento efectivo de sus responsabilidades y sus funciones. Dicha política pública también garantizará el cumplimiento de los fines esenciales del Estado y de los estándares en materia de Derechos Humanos para las Mujeres con un enfoque multisectorial y transversal.

- Ley 1496 de 2011

Por su lado, la Ley 1496 de 2011 busca "garantizar la igualdad salarial y cualquier forma de retribución entre hombres y mujeres" (Art. 1), así como los mecanismos para efectivizarla en el sector público y privado, y los lineamientos para erradicar cualquier forma de discriminación en lo que respecta a retribución laboral. Por tal razón, se fijaron unos factores salariales entre los que se encuentran: la naturaleza de la actividad a realizar, el acceso a los medios de formación profesional, las condiciones en la admisión del empleo, las condiciones de trabajo, la igualdad de oportunidades 
y trato en materia de empleo y ocupación y en otros complementos salariales. Se dispuso además que el Gobierno debería:

Desarrollar acciones y programas para garantizar la no discriminación de las mujeres en el trabajo y la aplicación del principio de salario igual a trabajo de igual valor, diseñar programas de formación y capacitación laboral para las mujeres, sin consideración de estereotipos sobre trabajos específicos de las mujeres, brindar apoyo tecnológico, organizacional y gerencial de las micro pequeñas y menores empresas dirigidas por mujeres, divulgar, informar y sensibilizar a la sociedad y a las mujeres sobre sus derechos laborales y económicos así como los mecanismos de protección de los mismos.

También garantizar a la mujer campesina el acceso a la propiedad o tenencia de la tierra y al crédito agrario, vigilar y controlar el cumplimiento de las normas sobre seguridad social a favor de las mujeres trabajadoras e imponer las sanciones legales cuando a ella hubiera lugar y realizar las evaluaciones periódicas sobre las condiciones de trabajo de las mujeres. (Ley 1496, 2011, Art. 8)

En lo anterior se observa como principal inquietud de los organismos internaciones y del Estado colombiano el reconocimiento de los derechos de las mujeres en general y, por ende, los de su núcleo familiar, para ello se ha reconocido la discriminación a la mujer especialmente en el ámbito profesional, estableciéndose allí la obligación de los Estados, especialmente el colombiano, de establecer medidas que le garantice a la mujer su desenvolvimiento en las diferentes esferas.

Es por todas las circunstancias en las que se ve obligada la mujer a asumir responsabilidades que debieran ser compartidos con sus parientes, que se amplió el concepto de "mujer madre cabeza de familia" a "mujer cabeza de familia" y por ende en ejercicio del derecho a la igualdad se extiende a los hombres que ejercen tan condición, en tanto que la obligación ya no solo radica en sus hijos, 
sino también otros miembros de su núcleo familiar, por ello también se ha tratado de idear e implementar mecanismos por parte del Estado para garantizar que la mujer pueda participar y por ende ingresar a los cargos que se encuentran comprendidos en las diferentes ramas del poder público, para ello también se ha definido un amplio desarrollo normativo tendiente a garantizar sus derechos especialmente los labores.

- CONPES 140 de 2011

Además de las leyes que acaban de ser mencionadas, conviene hacer referencia al documento de Política Pública CONPES 140 del Consejo Nacional de Política Económica y Social (2011) sobre metas y estrategias de Colombia para el logro de los Objetivos de Desarrollo del Milenio (ODM). En este documento se indica:

El ODM 3, relativo a la promoción de la igualdad de género y el empoderamiento de la mujer, tiene como meta implementar las acciones afirmativas para el aumento de la proporción de las mujeres candidatizadas, así como aumentar en más del 30\% la proporción de las mujeres en los niveles 1 y 2 de la Rama Ejecutiva y la Rama Judicial.

(Alta Consejería Presidencial para la Equidad de la Mujer, 2011, p. 6)

\section{Fundamento jurisprudencial}

Respecto al concepto y los derechos de la mujer, sobre todo de las que ejercen el rol de cabeza de familia, se han producido varios pronunciamientos por parte de las altas cortes, de los cuales se hará referencia a los que se consideran los más importantes para ello y luego del análisis de un considerable número de sentencias proferidas por la Corte Constitucional y el Consejo de Estado 
se traerá a colación las que la autora del trabajo consideró importantes y que tienen que ver directamente con el tema de la investigación.

- Sentencia C-184 de 2003

En la Sentencia C-184 de 2003 se definió a la mujer madre cabeza de familia así:

Quien siendo soltera o casada, tenga bajo su cargo económico o socialmente en forma permanente, hijos menores propios u otras personas incapaces o incapacitadas para trabajar ya sea por ausencia permanente o incapacidad fisca, sensorial psíquica o moral del cónyuge o compañero permanente o deficiencia sustancial de los demás miembros del núcleo familiar. (párr. 1)

En ese sentido, se indicó que el apoyo especial a la mujer cabeza de familia es una orden constitucional a todas las autoridades públicas para buscar la igualdad real y efectiva de ambos sexos, reconocer la pesada carga que recae sobre una mujer cabeza de familia y crear un deber estatal de apoyo en todas las esferas de su vida y su desarrollo personal; para compensar además la carga de sostener a su familia y para brindar de manera definitiva una protección especial a la familia como núcleo básico de la sociedad.

- $\quad$ Sentencia C-722 de 2004

En el mismo sentido, en la Sentencia C-722 de 2004 la Corte Constitucional afirmó que la razón por la cual la mujer cabeza de familia debe gozar de un amparo especial es porque ha estado expuesta a discriminación y marginamiento por muchos años. Asimismo, destaca el número significativo de mujeres que se han convertido en cabezas de familia asumiendo sin ningún apoyo 
la responsabilidad de su grupo familiar y de la labor o trabajo fuente de sustento de ella y de los suyos.

Agregó que en desarrollo de los principios de igualdad y protección especial del menor, las medidas de protección a las mujeres se extienden a los menores, así como las de un hombre que se encuentre en la misma situación descrita por la ley y la jurisprudencia que las madres cabeza de familia y a quienes por el ejercicio del derecho a la igualdad adquieren tal condición. La Corte recordó además la primacía de los derechos del menor:

[...] afirmada en la Constitución en plena armonía con las normas internacionales y en particular la Convención Sobre los Derechos del Niño, adoptada por la Asamblea General de las Naciones Unidas, ratificada por Colombia mediante la Ley 12 de 1991, [dicha primacía] ha sido tomada en cuenta por la Corporación para determinar el alcance de los derechos de los niños cuando ellos dependen de un núcleo familiar en el que solo uno de los padres se encuentra presente, para concluir que el sexo del padre de quien ellos dependen no puede privarlos de los derechos que les son reconocidos por la ley. (Sentencia C-722, 2004, párr. 3)

- Sentencia SU-388 de 2005

En la Sentencia SU-388 de 2005 se indicó que las acciones afirmativas nacieron del derecho norteamericano con la Ley Nacional de Relaciones Laborales de 1935 y consistía en que si un empresario discriminaba a un sindicato o empleado, este debía cesar en su actitud y a cambio optimizar acciones afirmativas y ubicarlas en el lugar que deberían estar si no hubieran sido discriminadas. 
Las acciones afirmativas surgen con el fin de restablecer o más bien compensar a las personas que habían sido discriminadas a lo largo de la historia, nivelar las condiciones de quienes luego de haber sido discriminados se vieron impedidos para disfrutar de sus derechos en las mismas condiciones que los demás e incrementar los niveles de participación especialmente en los escenarios políticos. Dicho en otros términos, las acciones afirmativas son el resultado del Estado Social de Derecho.

Advirtió la Corte que no toda mujer u hombre puede ser considerado como madre o padre cabeza de familia por el solo hecho de tener a cargo la responsabilidad del hogar, en tanto que para ser considerada así deben reunirse unos requisitos como son: que se tenga a cargo la responsabilidad de hijos menores o de otras personas incapacitadas para trabajar; que dicha responsabilidad sea de carácter permanente, no solo debe mediar la ausencia o abandono permanente del hogar por parte de la pareja, sino que además se sustraiga del cumplimiento de sus obligaciones como padre o madre; que la pareja asuma la responsabilidad que le corresponde y que ello se deba a un motivo poderoso como la incapacidad física, sensorial, psíquica o mental, o por muerte, y que haya una deficiencia sustancial de ayuda de los demás miembros de la familia.

- $\quad$ Sentencia T-626 de 2006

Se confirman los requisitos necesarios para que una mujer (o un hombre) sea considerada madre cabeza de familia de la siguiente manera:

(i) Que sus hijos propios, menores o mayores discapacitados, estén a su cuidado, que vivan con él, dependan económicamente de él y que realmente sea una persona que les brinda el cuidado y el amor que los niños requieran para un adecuado desarrollo y crecimiento; que sus obligaciones de apoyo, cuidado y manutención sean efectivamente 
asumidas y cumplidas, pues se descarta todo tipo de procesos judiciales y demandas que se sigan contra los trabajadores por inasistencia de tales compromisos.

(ii) Que no tenga alternativa económica, es decir, que se trate de una persona que tiene el cuidado y la manutención exclusiva de los niños y que en el evento de vivir con su esposa o compañera, ésta se encuentre incapacitada física, mentalmente o moralmente, sea de la tercera edad, o su presencia resulte totalmente indispensable en la atención de hijos menores enfermos, discapacitados o que médicamente requieran la presencia de la madre. (iii) Lo anterior, sin perjuicio de la obligación que le asiste de acreditar los mismos requisitos formales que la Ley 82 de 1993 le impone a la madre cabeza de familia para demostrar tal condición. En efecto, de conformidad con el parágrafo del artículo 2 de la Ley 82 de 1993: "esta condición (la de mujer cabeza de familia y en su caso, la del hombre cabeza de familia) y la cesación de la misma, desde el momento en que ocurra el respectivo evento, deberá ser declarada por la mujer cabeza de familia de bajos ingresos ante notario, expresando las circunstancias básicas de su caso y sin que por este concepto, se causen emolumentos notariales a su cargo. (Sentencia T-626, 2006, numeral 3 Ap. II)

Todo lo anterior significa que no se trata simplemente de que la mujer o el hombre demuestre que provee el dinero para la subsistencia del hogar, ni de asegurar las condiciones mínimas de subsistencia para sus hijos, sino que debe cumplir con los requisitos descritos anteriormente.

Entre los años 2006 a 2014 se produjeron otros pronunciamientos respecto del tema, los cuales no se traerán a colación pues no existe un argumento adicional a los ya referidos9 .

\footnotetext{
9 Sentencia C-989/2006- Mp. Alvaro Tafur Galvis. Sentencia T-090/2006- Mp. Jaime Córdoba Triviño Exp.T1197463-. Sentencia T-556/2006- Mp. Humberto Sierra Porto Exp T-1318757- Sentencia T-592/2006- Mp. Jaime Araujo Rentería Sierra Porto Exp T-1318708- Sentencia T-587/2008- Mp. Humberto Sierra Porto Exp T1525309-
} 
- Sentencia T-345 de 2015

En Sentencia T-345 de 2015 la Corte Constitucional hizo alusión a aquellas situaciones en materia laboral en las cuales la realidad no siempre coincide con lo pactado en el contrato verbalmente, tales como aquellos casos en que un contrato de prestación de servicios en realidad no lo es, situación que permite declarar la existencia de un contrato laboral.

Además, se estableció que en aquellos casos en que exista afectación de los derechos fundamentales de las madres cabeza de familia, adultos mayores, personas en situación de discapacidad u otros grupos vulnerables; debe existir una protección especial en situación de debilidad manifiesta, ante la posibilidad de que se trate de actos discriminatorios. En razón a ello las mujeres que tienen bajo su cargo en forma permanente la responsabilidad de los hijos menores propios o ajenos y de otras personas incapacitadas para trabajar y que dependan de ella, tanto afectiva como económicamente, deben gozar de protección especial.

Se observa de esta breve reseña jurisprudencial que las altas cortes se han pronunciado en varias oportunidades a favor de la mujer, desarrollando conceptos de gran envergadura como, por ejemplo, el de la mujer madre cabeza de familia el cual se extiende al hombre en dicha condición claro está en ejercicio del derecho a la igualdad Esto en aras de garantizar el apoyo a la

Sentencia T-833/2009- Mp. Maria Victoria Calle Correa Exp T-2326580 - Sentencia T-039/2010- Mp. Jorge Ivan palacio Palacio Exp T-2396452- Sentencia T-835/2012- Mp. Luis Ernesto Vargas Silva Exp.. T-3522717- Sentencia T-803/2013- Mp. Nilson Pinilla Pinilla Exp.. T-3918502- T-400/2014- Mp. Jorge Iván palacio Palacio Exp.. T4229757-Sentencis T-803/2013- Mp. Nilson Pinilla Pinilla Exp..Sentencia T-3918502-Sentencia T-345/2015- Mp. Nilson Pinilla Pinilla Exp.. T-3943316- Sentencia T-345/2015- Mp. Jorge Ignacio Pretelt Chajulb Exp.. T4.739.795. 
Mujer u hombre en esta situación desde el ámbito constitucional, ordenando a todas las autoridades que conforman el andamiaje público diversas medidas, para compensar así la carga que ha debido asumir con su núcleo familia, pero sobre todo para garantizar una verdadera protección especial.

Además de proteger los derechos de la mujer y del hombre en su condición de cabezas de familia, se trata de proteger de forma extensiva los derechos del menor, del adulto mayor o de las personas que conforman el núcleo familiar que se encuentran en estado de incapacidad; sin embargo, para que la mujer u hombre en tal condición tenga dicho reconocimiento especial es necesario que cumpla con una serie de requisitos como, por ejemplo, que las personas que se encuentran a su cargo se encuentren plenamente bajo su cuidado y que no exista una alternativa económica.

Se traen a colación algunas sentencias de la Corte Constitucional con el fin de demostrar que el problema planteado es latente, que en cualquier momento debe plantearse e implementarse las medidas correspondientes para garantizarle a las mujeres y hombres cabeza de familia que se encuentran vinculados en provisionalidad a cargos públicos su estabilidad, así como la de los miembros de su núcleo familiar. De esta manera podrá hacerse efectiva la protección especial otorgada por la Constitución Política de Colombia.

\section{La protección especial que el Estado debe brindar a las mujeres cabeza de}

\section{familia}

Peláez (2001) indica "la necesidad de llenar un vacío existente en el país, acerca de la sistematización, difusión y evaluación de experiencias empíricas, procesos y esfuerzos para 
institucionalizar las Políticas Públicas dirigidas a las mujeres” (p. 3). En este sentido es necesario, de un lado considerar el interés desde la academia de contribuir al fortalecimiento de la participación democrática y de la difusión de las investigaciones realizadas en el contexto regional y, de otro lado, con el ánimo de aportar herramientas para el esclarecimiento conceptual y el afianzamiento de los procesos de institucionalización de políticas con perspectiva de género.

Acosta (2007) señala que "el proceso de convocatoria a la Asamblea Nacional Constituyente, cuyo resultado fue la carta política actual, trajo consigo algunas innovaciones político jurídico, entre ellas la protección y consideración de los derechos de las personas" (p. 49), pero sobre todo el reconocimiento de las mujeres como sujetos de derecho en igualdad de condiciones que el hombre. El derecho constitucional de 1991 se acercó a las mujeres colombianas y a sus necesidades, pero quizás lo más importante fue el reconocimiento a sus derechos fundamentales.

El artículo 13 de la Constitución política de Colombia de 1991 establece la obligación del Estado colombiano de velar por la igualdad real y efectiva de las personas que se encuentren en situación de debilidad manifiesta, para ello se facultó al legislador para que adopte las medidas necesarias con el fin de que se materialicen las finalidades constitucionales; razón por la cual se ha adoptado las denominadas acciones afirmativas, las cuales ya han sido definidas en la jurisprudencia nacional como las "políticas o medidas dirigidas a favorecer a determinadas personas o grupos para efectos de eliminar las desigualdades y discriminaciones de índole social, económico o cultural" (Sentencia C-371, 2000, párr. 2).

Ahora bien, en ocasión a esa protección especial que debe proporcionar el Estado a ciertos grupos como las personas que están a punto de acceder a la pensión de vejez (los "pre 
pensionados" ${ }^{10}$ ) las personas con fuero sindical ${ }^{14}$, las personas con disminución física, psíquica o sensorial $^{1112}$, las mujeres embarazadas ${ }^{13}$, las madres y padres cabeza de familia y los portadores del VIH SIDA. Estas personas se encuentran relacionadas en el retén social con el fuero concedido por el Decreto 190 de 2003 y la Ley 790 de 2002, por lo cual no pueden ser retirados de sus empleos hasta que no se superen las causas de protección.

Vàsquez (2009) aseveró según lo indicado por la Corte Constitucional que del examen de las normas transcritas (artículos 8 y 12 de la Ley 790 de 2002) que la primera de ellas cobija a la generalidad de los empleados públicos de libre nombramiento y remoción y a aquellos que se encuentran nombrados provisionalmente y lo dispuesto en el artículo 12, está dirigido a los empleados públicos que se encuentran en una de estas tres condiciones: 1) Madres cabeza de

${ }^{10}$ Aquellas personas que se encuentran vinculadas mediante nombramiento provisional antes del 24 de septiembre del 2004 y a la fecha del decreto 3905 del 8 de octubre de 2009 les falten tres años o menos para obtener el derecho a pensión de jubilación. Están regulados por el Decreto 3905 del 2009, por el cual se reglamenta la Ley 909 de 2004, se dictan normas en materia de carrera administrativa y expresa cuáles son las personas que tienen la calidad de pre pensionados y cuáles son los requisitos para obtenerla. La Comisión Nacional del Servicio Civil profirió el Acuerdo No. 121 del 2009, el cual establece el procedimiento a seguir para ejecutar lo dispuesto en el Decreto 3905 de 2009.

${ }^{11}$ Personas que gozan de aquella garantía de rango constitucional que protege a los trabajadores y empleados públicos que pertenecen a las directivas del sindicato que sean miembros adherentes o fundadores de organizaciones sindicales mediante los cuales se materializan los derechos de una asociación.

${ }^{12}$ Mediante el Decreto 2177 de 1989 se materializa la readaptación profesional y empleo de personas inválidas. Dicho decreto desarrolló la Ley 82 de 1988, la Ley 361 de 1997, la Declaración de los Derechos Humanos proclamada por las Naciones Unidas en el año de 1948; la Declaración de los Derechos del Deficiente Mental aprobada por la ONU el 20 de diciembre de 1971; la Declaración de los Derechos de las personas con Limitación, aprobada por la Resolución 3447 de 1975; el Convenio 159 de 1983 de la OIT la cual habla sobre la readaptación profesional y el empleo de personas inválidas; la Declaración de las Naciones Unidas concerniente a las personas con limitación de 1983; la recomendación 168 de 1983 de la OIT; la Declaración de Cartagena de Indias sobre políticas integrales para las personas con discapacidad en el área iberoamericana; la Conferencia Intergubernamental Iberoamericana, en Cartagena, 23-30 octubre de 1992; las normas uniformes sobre la igualdad de oportunidades para las personas con discapacidad en las Naciones Unidas, Asamblea General, Resolución 48/96, 20 de diciembre de 1993 y por último, el Decreto 917 de 1999, Manual Único para la calificación de la Invalidez de 2014. Documentos como el emitido por CONPES 2761 de 1995 de la Vicepresidencia de la República, la cual establece la política de prevención y atención a la discapacidad. (Fajardo, 2014, p. 35)

${ }^{13}$ Dicha protección especial para la mujer cabeza de familia aplica no solo para las vinculas a cualquier entidad del Estado, sino de las vinculadas por contrato de servicios, dicha garantía deviene de la vulnerabilidad en la que se encuentran ellas y sus hijos por lo que se pretende la salvaguarda de la estabilidad laboral de las madres. 
familia sin alternativa económica; 2) Personas con limitación física, mental, visual o auditiva y 3) Servidores que cumplen con la totalidad de los requisitos, edad y tiempo de servicio, para disfrutar de su pensión de jubilación o de vejez en el término de tres (3) años contados a partir de la promulgación de dicha ley (p.94).

La protección especial a las mujeres y hombres cabeza de familia se deriva de lo dispuesto en la Constitución de 1991, la cual reconoció expresamente a la familia como el núcleo fundamental de la sociedad, siendo esta la razón primordial para que el Estado se concentre en el fortalecimiento de las relaciones, los derechos y obligaciones entre los individuos que las conforman. Esta tiene como misión primordial la transmisión de la vida a los hijos teniendo bajo su responsabilidad el de suministrarles el sustento diario, alimento, vestido, educación, etc.

En el año 2006 el Instituto de Seguro Social lanzó un programa para los pre-pensionados. Esta iniciativa va dirigida a las personas que se encuentran a menos de dos años de cumplir los requisitos para obtener la pensión de vejez. Según la jurisprudencia, En la mayoría de los casos la Corte resolvió a favor del pre pensionado (Casos resueltos a favor del pre pensionado: T-1045/07, T-1052/07, T-009/08, T-089/09, T-128/09, T-178/09); y en el único caso que no resolvió a favor, el accionante a pesar de estar inscrito en el Reten Social, cuando se enteró de la supresión del cargo que tenía, no interpuso recurso alguno, ni desplegó ninguna acción para cambiar dicha decisión; la Sala consideró que la acción de tutela instaurada no cumple con los requisitos de la inmediatez y de la subsidiaridad y presupuestos instituidos de su procedencia. (Fajardo, 2014, p. 34)

La Constitución Política de Colombia de 1991 planteó:

La familia es el núcleo fundamental de la sociedad. Se constituye por vínculos naturales o jurídicos, por la decisión libre de un hombre y una mujer de contraer matrimonio o por la voluntad responsable de conformarla. El Estado y la sociedad garantizan la protección integral de la familia. La ley podrá determinar el patrimonio familiar inalienable e inembargable. La honra, la dignidad y la intimidad de la familia son inviolables. Las 
relaciones familiares se basan en la igualdad de derechos y deberes de la pareja y en el respecto reciproco entre todos sus integrantes. Cualquier forma de violencia a la familia se considera destructiva de su armonía y unidad, y será sancionada conforme a la ley. Los hijos habidos en el matrimonio y fuera de el, adoptados o procreados naturalmente o con asistencia científica tienen iguales derechos y deberes. La ley reglamentará la progenitura responsable. La pareja tiene derecho a decidir libre y responsablemente el número de sus hijos y deberá sostenerlos y educarlos mientras sean menores e impedidos. Las formas de matrimonio, la edad y la capacidad para contraerlo, los deberes y derechos de los cónyuges, su separación y disolución del vínculo, se rigen por la ley civil. Los matrimonios religiosos tendrán efectos civiles en los términos que establezca la ley. Los efectos civiles de todo matrimonio cesarán por divorcio con arreglo a ley civil. También tendrán efectos civiles las sentencias de nulidad de los matrimonios religiosos dictadas por las autoridades de la respectiva religión, en los términos que establezca la ley. La ley determinará lo relativo al estado civil de las personas y los consiguientes derechos y deberes. (Art. 42).

A pesar de que la disposición constitucional hace referencia a que la familia se constituye por hombre, mujer e hijos, es más que claro que existen otras familias organizadas de manera diferente o personas que sin tener vínculos de sangre tienen el cuidado de personas a cargo, ya sea por un vínculo legal decisión judicial o administrativa o que carecen de formalidad. En el caso que ocupa al presente estudio, es obligación del Estado garantizar a la mujer y al hombre cabeza de familia un salario que le permita suministrar el sustento de su núcleo familiar y que en el evento de ser retirada o retirado del servicio se le otorgue no solo una indemnización, sino otras alternativas para que sus protegidos no se vean afectados con la desvinculación, y que estas sean extensivas a los padres que también cumplen el rol de cabeza de familia. A continuación, se analiza, partiendo del 
estudio jurisprudencial realizado por Fajardo (2014), si dicha protección especial a 2004 es real y efectiva.

\section{La acción de tutela, mecanismo principal para las mujeres cabeza de familia declaradas}

\section{insubsistentes}

La acción de tutela fue consagrada en la Constitución de $1991^{14}$ como aquel mecanismo que garantiza la protección de los derechos constitucionales y fundamentales de las personas en un procedimiento breve y sumario bajo el criterio de un Estado Social de Derecho democrático y pluralista, el cual propende por el mejoramiento de la calidad de vida de sus asociados.

Dicho mecanismo ha sido desarrollado a través de los Decretos 2591 de 1991 y 1382 de 2002. Mediante el primer decreto se reglamentó el objeto de la acción de tutela. Es indispensable analizar esta fuente de derecho a la hora de definir la procedencia de la acción de tutela. Por su parte, el segundo decreto determina las reglas para el reparto de las acciones de tutelas en aras de garantizar la imparcialidad y la protección eficaz de derechos fundamentales y constitucionales de los que en su sentir han sido afectados.

\footnotetext{
${ }^{14}$ Constitución Política de Colombia de 1991:
}

Toda persona tendrá acción de tutela para reclamar ante los jueces, en todo momento y lugar, mediante un procedimiento preferente y sumario, por sí misma o por quien actúe a su nombre, la protección inmediata de sus derechos constitucionales fundamentales, cuando quiera que éstos resulten vulnerados o amenazados por la acción o la omisión de cualquier autoridad pública. La protección consistirá en una orden para que aquel respecto de quien se solicita la tutela, actúe o se abstenga de hacerlo. El fallo, que será de inmediato cumplimiento, podrá impugnarse ante el juez competente y, en todo caso, éste lo remitirá a la Corte Constitucional para su eventual revisión. Esta acción solo procederá cuando el afectado no disponga de otro medio de defensa judicial, salvo que aquella se utilice como mecanismo transitorio para evitar un perjuicio irremediable. En ningún caso podrán transcurrir más de diez días entre la solicitud de tutela y su resolución. La ley establecerá los casos en los que la acción de tutela procede contra particulares encargados de la prestación de un servicio público o cuya conducta afecte grave y directamente el interés colectivo, o respecto de quienes el solicitante se halle en estado de subordinación o indefensión. (Art.86) 
Por otro lado, la Constitución Política de Colombia en su artículo 86, establece la acción de tutela como un mecanismo constitucional que puede ser utilizado por las personas que se consideran menguadas para que puedan reclamar la protección de sus derechos fundamentales y constitucionales, luego de reunir unos requisitos procesales. Fue por ello que la Constitución dejó abierta la posibilidad al ciudadano para que alegue la protección de sus derechos y los encuadre a las situaciones individuales que se les presente, en tanto que el catálogo de los derechos a la luz de la constitución es abierto Así lo refiere el artículo 2 del Decreto 2591 de 1991:

La acción de tutela garantiza los derechos constitucionales fundamentales. Cuando una decisión de tutela se refiera a un derecho no señalado expresamente por la Constitución, como fundamental pero cuya naturaleza permita su tutela para casos concretos, la Corte Constitucional le da prelación en la revisión de esta decisión (Decreto 2591, 1991, Art. 2)

La Corte Constitucional en sus diferentes pronunciamientos ha clasificado a grandes rasgos los derechos que son susceptibles del mecanismo de la acción de tutela de la siguiente manera:

- Los derechos fundamentales enunciados taxativamente en el artículo 85 de la Constitución, entre ellos, el derecho a la vida, a la igualdad, al libre desarrollo de la personalidad, el derecho de petición, el derecho al debido proceso, a la intimidad, al habeas data, a la libertad de cultos, a la libre expresión, a la intimidad, al trabajo, etc.

- Los derechos subjetivos descritos en el capítulo I del título II de la Constitución, son también denominados de aplicación judicial inmediata, que no se catalogan como individuales, sino que involucra a muchas personas confluyendo, además de muchos factores sociales, políticos, económicos etc. 
- Los derechos que componen el bloque de constitucionalidad. Los derechos que conforman el bloque de constitucionalidad han sido definidos como aquellos derechos que no se encuentran contemplados expresamente en la Constitución, pero que se encuentran comprometidos como criterio orientador que permite aplicar el derecho internacional de los derechos humanos y el derecho internacional humanitario al derecho interno, es por ello que el tribunal constitucional ha proferido varios fallos dando aplicación al bloque de constitucional en las leyes nacionales.

- Los derechos fundamentales innominados

Aquellos derechos que como su nombre lo indica no se encuentran textualmente citados, aunque se encuentran revestidos de gran importancia para la garantía de la dignidad humana de las personas. Entre ellos está el derecho al mínimo vital, a la seguridad personal, y el que le incumbe al presente trabajo, el derecho a la estabilidad laboral reforzada de sujetos de especial protección constitucional. Frente a estos últimos la Corte Constitucional ha considerado que en algunos casos el derecho a la estabilidad laboral consagrado en la Constitución ${ }^{15}$ amerita una mayor protección. Por tal razón en Sentencia T- 519 de 2003 estableció unos requisitos para que la acción de tutela proceda para la protección especial y, en consecuencia, se produzca el reintegro laboral:

(a) En principio no existe un derecho fundamental a la estabilidad laboral.

(b) Frente a ciertas personas se presenta una estabilidad laboral reforzada en virtud de su especial condición física o laboral, o por encontrarse dentro de grupos poblacionales tradicionalmente marginados o discriminados.

\footnotetext{
${ }^{15}$ Constitución Política de Colombia de 1991:El Congreso expedirá el estatuto del trabajo. La ley correspondiente tendrá en cuenta por lo menos los siguientes principios mínimos fundamentales: Igualdad de
} 
(c) Si se ha presentado una desvinculación laboral de una persona que reúna las calidades de especial protección, la tutela no prosperará por la simple presencia de esta característica.

(d) Será necesario probar la conexidad entre la condición protegida y la desvinculación laboral, constitutiva de un acto discriminatorio y un abuso del derecho.

(e) La tutela puede ser el mecanismo para el reintegro laboral de las personas que por sus circunstancias particulares ameriten la protección laboral reforzada. En todos los casos es necesario mostrar la afectación de un derecho fundamental como el mínimo vital, la dignidad o el derecho de asociación sindical.

oportunidades para los trabajadores; remuneración mínima vital y móvil, proporcional a la cantidad y calidad de trabajo; estabilidad en el empleo; irrenunciabilidad a los beneficios mínimos establecidos en normas laborales; facultades para transigir y conciliar sobre derechos inciertos y discutibles; situación más favorable al trabajador en caso de duda en la aplicación e interpretación de las fuentes formales de derecho; primacía de la realidad sobre formalidades establecidas por los sujetos de las relaciones laborales; garantía a la seguridad social, la capacitación, el adiestramiento y el descanso necesario; protección especial a la mujer, a la maternidad y al trabajador menor de edad. El estado garantiza el derecho al pago oportuno y al reajuste periódico de las pensiones legales. Los convenios internacionales del trabajo debidamente ratificados, hacen parte de la legislación interna. La ley, los contratos, los acuerdos y convenios de trabajo, no pueden menoscabar la libertad, la dignidad humana ni los derechos de los trabajadores. (Art.53)

(f) El reintegro no tendría lugar de presentarse una justa causa para la desvinculación y siempre que esta se hubiera producido con el respeto del debido proceso correspondiente. En estos casos para satisfacer esta condición se requiere el permiso previo del despido. (Botero, s.f., p. 30)

Los parámetros anteriormente establecidos por el Tribunal Constitucional tienen como finalidad evitar que la acción de tutela y la protección especial sean utilizadas de manera superficial por personas que no posea en verdad dicha condición y que pretendan alegar dicha protección. 
En la Constitución de $1991{ }^{16}$ y el Decreto 2591 de $1991{ }^{17}$ se ha dejado claro que si bien en el universo de los derechos existen unos que no ostentan la misma envergadura, los derechos constitucionales y fundamentales pueden ser protegidos a través de la acción de tutela, siempre y cuando implique la vulneración indirecta de un derecho fundamental constitucional. Entre estos se encuentran los derechos a la seguridad social, el derecho al medio ambiente, entre otros. En el capítulo 2 del título II de la Constitución y también en los derechos colectivos consagrados en el capítulo 3 del título II, aparecen derechos que no se pueden alegar directamente vía tutela, por lo que deben ser desarrollados de manera progresiva por el legislador y es procedente dicha acción en algunos casos excepcionales cuando su vulneración atenta contra un derecho fundamental.

En lo que tiene que ver con la declaratoria de insubsistencia de las mujeres y hombres cabeza de familia que se encuentran vinculados provisionalmente a cargos públicos, si bien existen mecanismos ordinarios para la protección de derechos de índole subjetivos, que como la acción de nulidad y restablecimiento del derecho no resultan inmediatos, la acción de tutela se ha convertido en el mecanismo principal al cual acceden los declarados insubsistentes. Esto en razón a que es el medio más expedito para lograr el reintegro a sus cargos, en tanto que han encontrado apoyo en la Corte Constitucional que ha proferido un número importante de fallos en donde reconoce los

${ }^{16}$ Constitución Política de Colombia de 1991: "La enunciación de los derechos y garantías contenidos en la Constitución y en los convenios internacionales vigentes, no debe entenderse como negación de otros que, siendo inherentes a la persona humana, no figuren expresamente en ellos" (Art. 94).

${ }^{17}$ Decreto 2591 de 1991. Derechos protegidos por la tutela.

La acción de tutela garantiza los derechos constitucionales fundamentales. Cuando una decisión de tutela se refiere a un derecho no señalado expresamente por la Constitución como fundamental, pero cuya naturaleza permita su tutela para casos concretos, la Corte Constitucional le dará prelación en la revisión a esta decisión. (Art. 2) 
derechos fundamentales al debido proceso y el derecho a la defensa, al no motivarse los actos administrativos discrecionales en vocación al mejoramiento del servicio.

Sin embargo, ello no implica que la situación del accionante haya sido resuelta de manera definitiva, pues en el momento en que se surta el correspondiente concurso de méritos, el funcionario será removido de su cargo, sin tener en cuenta el tiempo que ha ejercido en la entidad, las capacitaciones que ha recibido y que le permiten tener un conocimiento más profundo de las funciones que allí se desempeñan respecto de la persona que luego de superar el concurso de méritos ingresa a la entidad correspondiente. Pero quizás lo más importante es que ellos serán declarados insubsistente y como consecuencia de ello menores de edad, adultos mayores o personas con discapacidad se verán afectados posiblemente en varios de sus derechos fundamentales. Por esta razón fue necesario condicionar el acceso a la acción constitucional.

A continuación, se trae a colación un análisis importante desde el punto de vista jurisprudencial al año 2014 realizado por Fajardo (2014), en donde trató de analizar en general la situación de los grupos vulnerables que se encuentran vinculados a cargos públicos de manera provisional.

Si es procedente el retiro del servicio de los servidores públicos que tienen calidad de padre o madre de familia, mediante la declaración de insubsistencia, que siendo personas con especial protección constitucional, merecen una estabilidad laboral reforzada por parte del Estado. (p. 156) 
Dentro de dicho trabajo la autora mencionó las sentencias C-964 de 2003 ${ }^{18}$ C-1039/03 de $2003^{19}$ C- $044 / 04$ de $2004^{20}$ C-1128/04 de $2004^{21}$ T-593/06 de $2006^{22}$ de la Corte Constitucional, indicando que este Tribunal en Sentencia T-593 de 2006 planteó que es improcedente la acción de tutela cuando la tutelante no alega ni demuestra la calidad de madre o padre cabeza de familia ante la entidad que declara su insubsistencia.

Asimismo, luego del estudio juicioso de la jurisprudencia, es decir de las sentencias que a continuación se relacionan en el orden del trabajo, la autora realizó una serie de conclusiones importantes, como que en la mayoría de casos la Corte Constitucional resolvió a favor de la madrepadre cabeza de familia, y que en los casos en que las peticiones no fueron resueltas a favor, fue por el condicionamiento en el tiempo de las personas que fueron reconocidas dentro del retén social, pues estaría vigente mientras dure el programa de renovación institucional.

En los casos de supresión y liquidación de una empresa del Estado, la indemnización es considerada por la Corte no solo como una forma de compensación, sino también como un mecanismo para evitar un perjuicio irremediable, al recibirse como consecuencia del proceso de

\footnotetext{
${ }^{18}$ Madre cabeza de familia -Antecedentes de la protección especial en la Asamblea Nacional Constituyente -Debe obrar igualdad respecto de los beneficios que se le reconocen a la mujer cabeza de familia frente a los hombres. Dr. Álvaro Tafur Galvis.

${ }^{19}$ Se hace referencia al Programa de renovación de la Administración pública -Madre cabeza de familia -Protección al grupo familiar que de ella depende -Estabilidad laboral -Protección especial a madre cabeza de familia puede extenderse a los padres que se encuentran en la misma situación. Dr. Alfredo Beltrán Sierra.

${ }^{20}$ Madre cabeza de familia en programa de renovación de la Administración pública -Prohibición del retiro del servicio a las madre o padre cabeza de familia sin alternativa económica del servicio público en el desarrollo del Programa de Renovación de la Administración Pública. M.P Dr. Jaime Araujo Rentería.

${ }^{21}$ Protección de madres cabeza de familia y discapacitadas ante renovación de la Administración. M.P Dr. Alfredo Beltrán Sierra.

${ }^{22}$ Madre cabeza de familia en proceso de reestructuración administrativa -No adquiere tal condición sólo por desempleo de la pareja -Persona interesada debía acreditar de manera suficiente y oportuna su condición -Acciones afirmativas de especial protección -Estabilidad laboral de madre cabeza de familia -Garantía constitucional
} 
reestructuración, y donde no es procedente la acción de tutela. En otros casos, la accionante no demostró ostentar la calidad de madre o padre cabeza de familia, razón por la cual no prosperó la acción.

La Corte aclaró que si bien se le deben proteger los derechos y dar una estabilidad laboral reforzada a dichas personas con especial protección por parte del Estado, no se deben quitar los derechos ya adquiridos por otras personas que no ostentan dicha calidad. En uno de los casos en particular, la accionante no era titular del cargo que desempeñaba y la razón de su desvinculación fue por el hecho de que a la titular -perteneciente a carrera administrativa- se le dio por terminado su encargo. Por tal razón, se le dio prioridad a la titular del cargo, ya que la protección constitucional que se predica de los sujetos de especial protección, y desarrollada en normas de inferior jerarquía, no puede extenderse a situaciones en las que existen causas justas para dar por terminada la relación laboral. (Fajardo, 2014, p. 182)

Las sentencias constitucionales que no fueron tuteladas por el juez constitucional y que fueron analizadas por la autora son las siguientes: Sentencia T-876 de $2004^{23}$, T-530/05 de $2005 .^{24}$, T 834

\footnotetext{
${ }^{23}$ Protección especial, se indicó que quienes reciban una indemnización en ocasión a la supresión y liquidación de la empresa se les pagará una indemnización por la terminación del contrato, sin embargo en caso de indemnización no es procedente la acción de tutela sino las acciones ordinarias pertinentes y que en caso de demostrarse que no existió la indemnización podría demostrarse el perjuicios irremediable, por ende es procedente la acción constitucional. M.P Dr. Alfredo Beltrán Sierra

${ }^{24}$ Derecho a la estabilidad laboral reforzada de madres cabeza de familia y de personas que padecen una enfermedad y que son declaradas insubsistentes, en esta decisión se reconoce los derechos fundamentales de la accionante, sin embargo se determinó que no era pertinente el reintegro dadas las condiciones de salud y por el contrario, se ordena tramitar de manera "inmediata y preferente" de la pensión de invalidez a la actora de la acción de tutela. M.P Dr. Manuel José Cepeda Espinosa.
} 
de $2005^{28}$, T-231 de 2006 ${ }^{25}$, 68001-23-15-000-2006-1031-01 ${ }^{26}$, T-303 de 2006 27 25000-2327-000$2007-00255-0^{28}, \mathrm{~T}-837$ de $2007^{29}, \mathrm{~T}-453$ de $2008^{30}, \mathrm{~T}-587$ de $2008^{31}$, T-1211 de $2008^{32}$.

Además de la acción de tutela como se indicó anteriormente a este grupo de personas le es procedente acceder a la acción de nulidad y restablecimiento del derecho siempre y cuando el acto administrativo que declara la insubsistencia sea debidamente motivado bajo las circunstancias particulares y concretas de hecho y de derecho por las cuales se decide remover a un determinado funcionario de manera que no resulten variables aquellas justificaciones indefinidas, generales y abstractas, que no se predican directamente de quien es desvinculado" (Sentencia T 147 de 2013 Corte Constitucional).

\footnotetext{
${ }^{25}$ Significado y alcance de la protección constitucional en procesos de reforma institucional -Especial protección laboral, se negó la acción de tutela en tanto que la tutelante no alegó ni demostró antes ni en la desvinculación su condición de madre cabeza familia como otras personas si lo hicieron, esperando hasta los dos años de su desvinculación para alegarla por lo que los beneficios alegados no tienen carácter retroactivo. M.P. Dr. Rodrigo Escobar Gil.

${ }^{26}$ Se negó el derecho alegado por quien se consideraba padre cabeza de familia, pues simplemente se limitó a referir que estaban a su cargo sus hijos e hijastros C.P. Martha Sofía Sanz Tabón.

${ }^{27}$ Se denegó la protección especial, pues la accionante no demostró los requisitos exigidos en el retén social. M.P. Dr. Rodrigo Escobar Gil.

${ }^{28}$ No se tutelaron los derechos fundamentales alegados por los accionantes en tanto que no demostraron tal condición, simplemente se limitaron a indicar que de su trabajo dependían sus hijos menores y que de sus ingresos depende su congrua subsistencia. C.P Rafael. Ostau de Lafont Pianota.

${ }^{29}$ Se deniega la acción de tutela en tanto que el actor no demostró su calidad de Padre cabeza de familia TelecomCaso en que no se cumplen presupuestos para protección laboral reforzada, en tanto que no se demostró que ninguno de sus hijos padece enfermedad o que su esposa es discapacitada. M.P. Dra. Clara Inés Vargas Hernández.

${ }^{30}$ Acción de tutela contra Telecom en liquidación - temeridad. Madre cabeza de familia, en tanto que ya otro juez constitucional ya había conocido del asunto M.P. Dr. Manuel José Cepeda Espinosa.

${ }^{31}$ Acción de tutela contra empresa de telecomunicaciones y patrimonio autónomo regional- Terminación contrato de trabajo de madres cabeza de familia, sin embargo el cargo no era de carrera administrativa por lo que fueron indemnizadas en su momento, la empresa fue disuelta y liquidada por lo tanto no hay un cargo equivalente M.P. Dr. Humberto Antonio Sierra Porto.

${ }^{32}$ La accionante no demostró estar absolutamente a cargo de su hijo, ni tampoco que el padre de él lo haya abandonado. Reestructuración de entidad del Estado - Madre cabeza de familia. M.P. Dra. Clara Inés Vargas Hernández.
} 


\section{Vulneración de derechos fundamentales y económicos de la mujer cabeza de familia con la declaratoria de su insubsistencia}

Se entiende por constitución económica el conjunto de principios, criterios, valores y reglas que deben regir la economía de un país, según el modelo económico adoptado por este, pero sobre todo según el modelo de Estado que se busca garantizar. Por lo tanto, una constitución económica es el producto de la relación interdependiente entre el derecho y la economía.

\footnotetext{
${ }^{28}$ Se denegó la acción de tutela pues, se demostró que la accionante no fue discriminada por su estado de embarazo pues la terminación de los contratos fue masiva, no logró demostrar la condición de mujer cabeza de familia más aun cuando se demostró que su pareja no había abandona el hogar por lo tanto estaba bajo su responsabilidad la manutención de la familia.

Dicha constitución debe tener en cuenta los principios que inspiran la organización del Estado y la manera en que este abordará el derecho a la propiedad privada, que es sin lugar a dudas el objetivo más importante del ser humano en ejercicio de un derecho individual garantizado por el mismo. También debe comprender los principios que regularán la libertad contractual y de competencia, así como el grado de intervención que ejercerán las instituciones públicas en la actividad económica privada, todo en pro de los derechos individuales y colectivos de los administrados.
}

Como se refirió en otra oportunidad, el Estado Social de Derecho establecido por la Constitución de 1991 trajo implícito la definición y protección de los derechos individuales y colectivos de los asociados, así como la disyuntiva del interés particular frente al interés general, imponiéndole al Estado la obligación de equiparar los dos conceptos de una manera armónica. Razón por la cual podría decirse que reconoce no solo derechos liberales, sino también económicos sociales y culturales, pero al mismo tiempo es una constitución amplia o abierta; dado que a pesar de ser 
valorativa-normativa, reconoce derechos fundamentales y por lo tanto las políticas económicas son limitadas por esta.

La Carta Magna colombiana trajo consigo el desarrollo del concepto del nuevo derecho constitucional económico, el cual surge como una reacción a los problemas de la desigualdad social que aqueja no solo a nuestro país sino a todo el mundo. Surge de la necesidad de consagrar los valores de la justicia, la paz social a través del ejercicio directo de los principios de igualdad, solidaridad y el reconocimiento de los derechos civiles y económicos de los individuos.

La Corte Constitucional en Sentencia C-074 de 1993 refirió en su parte argumentativa que la Constitución tiene un corte teleológico que recogió la doctrina constitucional contemporánea y consagra un modelo de Estado interventor a través de un conjunto sistemático de disposiciones jurídicas encaminadas a la realización de un orden económico social y justo, dentro del marco de nuestro Estado Social de Derecho.

En razón a lo anterior, Colombia hace parte del Pacto Internacional de Derechos Civiles y Políticos, adoptado por las Naciones Unidas en el año de 1966 y ratificado por el Estado Colombiano en el año de 1969, pacto en el cual, en su capítulo III, hizo mención a los derechos económicos, sociales y culturales de las personas. La participación del país en dicho pacto tuvo como fundamento jurídico unos derechos que implican la prestación por parte del Estado de una erogación de tipo económico y que, así mismo, se incluyeron en los convenios internacionales de trabajo debidamente ratificados (Asamblea General de la ONU, 1966).

Además de los mecanismos y tratados internacionales de los cuales debe hacer parte el Estado, también deben existir pactos y mecanismos de derechos humanos regionales que permitan la materialización de los derechos económicos de los ciudadanos, en este caso de la mujer, que de todas maneras implica hablar de los mismos derechos del otro género; en tanto que en el Estado 
Social de Derecho colombiano se propugna por la igualdad entre las unas como los otros. Sin embargo, se evidencia el papel central de la mujer en lo relacionado con la pobreza y la misma desigualdad, pues es por su rol de madres, esposas e hijas que conocen directamente la importancia de la adquisición de los alimentos, el acceso a la vivienda, el acceso a la educación para sus hijos, al saneamiento básico, el acceso al trabajo, etc. Esta situación es aún más evidente cuando ejercen la calidad de madres cabeza de familia, no contando en este caso con el apoyo económico del padre de sus hijos, sino que son ellas las que deben enfrentar y cubrir las necesidades básicas de sus familias.

Resulta importante decir que el 3 de enero de 1996 entró a regir en Colombia el Pacto Internacional de Derechos Económicos, Sociales y Culturales, en virtud de la Ley 74 de 1976 y el 16 de noviembre de 1999 el protocolo adicional a la Convención Americana de Derechos Humanos en materia de Derechos Económicos, Sociales y Culturales "Protocolo de San Salvador", adoptado como legislación interna mediante la Ley 389 de 1996. Con base en dicho pacto se dice que los derechos humanos están íntimamente ligados entre sí, que son indivisibles y, por ende, tienen la misma relevancia para la dignidad humana. En consecuencia se pueden catalogar como derechos económicos de la mujer los siguientes:

El derecho a la no discriminación e igualdad, teniendo el Estado la obligación de garantizar la no discriminación a las mujeres a través de las leyes o de la práctica, así como que gocen de los mismos derechos económicos de los que disfrutan los hombres.

El derecho al trabajo, permitiéndoles a las trabajadoras que tengan la posibilidad de ganarse la vida por medio de un trabajo elegido libremente, en el cual perciban un salario justo y que en nada degraden su dignidad humana. 
El derecho a salud y a la seguridad social, con el cual se garantiza que las mujeres puedan tener acceso a los bienes y servicios adecuados necesarios para tener una vida digna, debiéndose proteger a las trabajadoras de la falta de ingresos procedente del trabajo, debido a enfermedades de invalidez, maternidad, accidente laboral y vejez.

El derecho a la propiedad, dado que Colombia ha reconocido a las mujeres el derecho a la propiedad y a la tierra en el año de 1988 en la Ley 30 con la reforma agraria, pero fue con la Constitución de 1991 en donde se consagró la igualdad de derechos y oportunidades de propiedad entre los dos géneros.

El derecho a la vivienda, el cual abarca todos los elementos esenciales para garantizar una vida digna, debiendo el gobierno desarrollar políticas nacionales que garanticen dichos derechos a todas y todos los ciudadanos.

El derecho al agua y al saneamiento, para garantizarle a su núcleo familiar el acceso a estos servicios, claro está, percibiendo el Estado una contraprestación económica por parte de los usuarios.

El derecho a la alimentación, significando este derecho que todas las personas, las madres cabeza de familia y su núcleo familiar, puedan tener acceso físico y económico a la alimentación o por lo menos puedan tener los medios para producirla; en este caso a través de su empleo y de la vinculación provisional a un cargo público, debiendo el Estado garantizarles el derecho a poseer.

El derecho a la educación, quizás es la preocupación más importante para la madre y mujer cabeza de familia, debido a que es a través de la educación que se puede de una u otra manera forjar una expectativa de calidad de vida para sus hijos, por ende a todo su núcleo familiar. A pesar de que la educación debe ser gratuita, en el Estado colombiano ello no se da, debiendo la madre incluirla dentro de sus gastos mensuales, los cuales pagará con el producto de su trabajo. 
Como se ha referido anteriormente, el artículo 43 de la Constitución de 1991 consagra la protección especial de la mujer madre cabeza de familia en aras de hacer más llevadero el rol que deben ejercer dentro de su hogar y su papel de trabajadoras protección que se extiende por desarrollo jurisprudencial a los hombres cabeza de familia. Asimismo, la Ley 82 de 1993 establece las normas para apoyar de manera especial a las madres cabeza de familia, atribuyéndole al Estado la obligación de promover políticas para facilitarles el acceso a la vivienda digna, la educación para sus hijos, la seguridad social, el trabajo y su estabilidad; dado que son ellas quienes sostienen moral y materialmente el núcleo familiar disfuncional, razones suficientes para obligar al Estado a fomentar la intención y materialización del desarrollo empresarial de las mujeres en esta condición.

Dicha ley dispone que las mujeres que tengan la condición de madres cabeza de familia serán sujetos de especial protección y, en ese sentido, el Estado tendrá la obligación de promover acciones para facilitar la educación de sus hijos, el acceso a la vivienda, a la seguridad social, el fomento para el desarrollo empresarial, capacitaciones e incentivos, entre otros.

Fue a través de la Ley 790 de 2002 que se expidieron disposiciones para adelantar el programa de renovación de la administración pública y se otorgaron facultades extraordinarias al Presidente de la República, para promover la estabilidad laboral, el respeto a la dignidad humana y los demás derechos económicos de las mujeres madres cabeza de familia.

Dicha ley tuvo por objeto renovar y modernizar la estructura de la rama ejecutiva del orden nacional y procurar la estabilidad financiera de la Nación, y trató de subsanar la duplicidad de funciones, pero principalmente reglamentar la fusión de entidades y organismos nacionales con funciones afines y que atravesaran por alguna de las circunstancias especiales allí descritas ${ }^{37}$. 
37 Artículo $2^{\mathbf{0}}$. Fusión de entidades u organismos nacionales. El Presidente de la República, como suprema autoridad administrativa, de conformidad con lo dispuesto en el numeral 15 del artículo 189 de la Constitución Política, podrá disponer la fusión de entidades u organismos administrativos del orden nacional, con objetos afines, creados, organizados o autorizados por la ley, cuando se presente al menos una de las siguientes causales:

a) Cuando la institución absorbente cuente con la capacidad jurídica, técnica y operativa para desarrollar los objetivos y las funciones de la fusionada, de acuerdo con las evaluaciones técnicas;

b) Cuando por razones de austeridad fiscal o de eficiencia administrativa sea necesario concentrar funciones complementarias en una sola entidad;

c) Cuando los costos para el cumplimiento de los objetivos y las funciones de la entidad absorbida, de acuerdo con las evaluaciones técnicas, no justifiquen su existencia;

d) Cuando exista duplicidad de funciones con otras entidades del orden nacional;

e) Cuando por evaluaciones técnicas se establezca que los objetivos y las funciones de las respectivas entidades u organismos deben ser cumplidas por la entidad absorbente;

Se indicó también que la entidad absorbente deberá cumplir a cabalidad con el objeto de la entidad absorbida, que el régimen de contratación y de vinculación de los servidores públicos será el establecido para la entidad absorbente y que al funcionario a quien se seleccione para pertenecer a la dominante tiene dos opciones frente a dicha situación: la primera, recibir una compensación por los salarios y prestaciones que no recibirá en ocasiones a las disposiciones de la nueva entidad $\mathrm{y}$, la segunda, acogerse al nuevo régimen, sin ser desmejorado en lo que de prestaciones económicas y salarios se trata.

También se dispuso allí un reconocimiento o especie de subsidio para procurar la rehabilitación profesional y técnica de los empleados públicos vinculados en las modalidades de libre nombramiento y remoción y por nombramiento provisional en cargos de carrera administrativa, que sean retirados del servicio o por supresión del cargo en un porcentaje no inferior al (50\%) de la asignación básica y que se pagará en un plazo de doce meses.

Fue en el articulo 12 de la ley 790 de 2002 en donde se contempló una protección especial a las madres cabeza de familia sin alternativa económica, disponiéndose que no pueden ser retirados del 
servicio en desarrollo del Programa de Renovación de la Administración Pública, los grupos considerados como vulnerables, entre ellos además, las personas con limitación física y mental, visual o auditiva y los servidores que cumplan con los requisitos establecidos para obtener su pensión de jubilación o de vejez, en tres (3) años contados a partir de la promulgación de la ley en mención.

f) Cuando la fusión sea aconsejable como medida preventiva para evitar la liquidación de la entidad absorbida. Cuando se trate de entidades financieras públicas, se atenderán los principios establecidos en el Estatuto Orgánico del Sistema Financiero

Se observa que con dicha ley se pretende reconocer sus derechos a los servidores públicos que pertenezcan a la entidad vencida, y a los grupos con protección especial que dispuso la constitución y que en su momento se mencionaron en el presente trabajo. Por ello, es viable advertir que el Estado deberá en el momento que defina la situación de los empleados vinculados en provisionalidad tener en cuenta tales circunstancias y procurar la mínima afectación de derechos en el caso del presente análisis de las mujeres y hombres cabeza de familia y su núcleo familiar (menores de edad, adultos mayores y personas en discapacidad).

En Sentencia T-768 de 2005 la Corte Constitucional hizo alusión a la protección laboral reforzada de las madres cabeza de familia, protección especial que además garantiza la materialización de los derechos económicos de las mismas y del núcleo familiar, en tanto que el amparo se extiende a los niños y personas de la tercera edad que están a su cargo. Es por ello que las autoridades públicas deben garantizar dichos derechos fundamentales, económicos, sociales y culturales. 
Para resumir, en esta tesis se trata de determinar si el acto discrecional que declara la insubsistencia en dichos cargos, vulnera o no los derechos económicos de las mujeres madre o padre cabeza de familia y de paso, los de su núcleo familiar. Y en efecto, puede concluirse que sí existe tal vulneración, en tanto que como se ha analizado, prima la obligación de proveer sus cargos con personas que han superado el concurso de méritos, pudiendo en cualquier momento ser removidas de sus cargos, lo cual resulta paradójico pues la Constitución de 1991 tuvo como principal finalidad la materialización y reconocimiento de los derechos económicos individuales y colectivos de las personas.

En caso de que al realizarse la correspondiente ponderación de derechos respecto de las mujeres y/u hombres cabeza de familia que se encuentran vinculados en provisionalidad al Estado, se considera que debe primar la obligación de proveer los cargos luego de superar el concurso de méritos y que como consecuencia deben ser declarados insubsistentes, se estaría dejando de lado los planteamientos que soportan nuestro estado social de derecho, los diversos pronunciamientos de la corte constitucional, las leyes expedidas para garantizar la protección especial a este grupo de personas y su núcleo familiar, por lo que es indispensable que el Estado adopte una decisión de fondo que soluciones la situación de las personas vinculadas hace varios años y de esta manera se garantice, en adelante, que los cargos vacantes sean proveídos con personas que superen el concurso de méritos, con ello no se plantea erradicar la provisionalidad como forma de vinculación al Estado en tanto que ese no es problema jurídico planteado, sino proyectar y sugerir posibles soluciones a las personas que poseen la condición de madres o padres cabeza de familia que se encuentran vinculados bajo la forma excepcional.

Dadas las características del empleo provisional, es decir, la discrecionalidad, la excepcionalidad y transitoriedad del mismo; se ha generado una inestabilidad en las personas, en 
este caso las mujeres y hombres cabeza de familia que ocupan dichos cargos. Esta afirmación se puede corroborar en otros pronunciamientos de la Corte Constitucional entre ellos la Sentencia-T 884 de 2002, la T-610/03 de 2003 en las cuales se considera que sí existen derechos que deben ser reconocidos y garantizados por el Estado a los servidores nombrados en provisionalidad a continuación un breve análisis de las sentencias referidas.

La sentencia T-884 de 2002 Magistrado Ponente Clara Inés Vargas Hernández, mediante la cual se realizó la revisión de fallos de instancia y se analizó la acción de tutela instaurada por la señora Clara Aurora Maya Gómez, con el fin de revocar o dejar sin efectos la Resolución No.

0180 calendada del cuatro (4) de febrero de dos mil dos (2002), mediante la cual la Fiscalía General de la Nación decidió declarar insubsistente su nombramiento en el cargo de profesional universitario grado I. La primera instancia resolvió tutelar sus derechos fundamentales al trabajo, la estabilidad laboral, la salud, la seguridad social y los derechos de los niños, bajo el argumento principal de que existió ruptura del vínculo laboral vulneran do a prerrogativa de la actora de permanecer en el cargo, que la insubsistencia implicó el dejar de percibir ingresos económicos para su subsistencia pero para principalmente para sus menores hijos a quienes no le pudo solventar sus necesidades básicas fundamentales, como a la alimentación, la educación, la salud entre otras. Pero quizás el argumento jurídico más importante es que la Fiscalía General de la Nación, no motivó el acto administrativo que declaró la insubsistencia por lo que no existió causal justificada.

Por su parte, la segunda instancia consideró que el hecho de que la acción tuviera la condición de madre cabeza de familia de dos hijos menores, no le acarreaba consecuencias o perjuicio irremediable la declaratoria de la insubsistencia, pues su progenitor laboraba, además que la accionante contaba con 30 años de edad por lo que tenía plena capacidad productiva y laboral. 
Finalmente la corte constitucional decidió revocar la sentencia proferida por la segunda instancia, dejando con efectos la sentencia de primera instancia que había tutelado los derechos fundamentales de la actora bajo el argumento principal que la estabilidad laboral de un funcionario que ocupa un cargo de carrera administrativa no se reduce por el hecho de que lo haga en provisionalidad, puesto que este no se convierte en un cargo de libre nombramiento y remoción, por lo que el nominador no puede desvincular al servidor de manera discrecional.

También consideró que en cuanto a la inexistencia del perjuicio irremediable argumentado por el funcionario ad quem, la sala se apartó considerando que si bien la accionante era una persona de 30 años de edad y con capacidad profesional y productiva, esto no garantizaba que pudiera acceder al mercado profesional fácilmente y que por lo tanto su mínimo vital y el de sus hijos menores se vería gravemente afectado.

La sentencia T- 610 de 2003, Magistrado Ponente Alfredo Beltrán Sierra, estudió la acción de tutela interpuesta por la actora quien fue nombrada en provisionalidad en el hospital departamental de Nariño en el cargo de profesional universitario y que posteriormente fue declarada insubsistente sin motivación alguna, a pesar de gozar de la protección especial de permanencia pues había dado a luz en el mes de julio del año de 2002 y que su esposo se encontraba desempleado por lo que no poseían recursos económicos para pagar el arriendo y demás gastos para su subsistencia.

En fallo de única instancia se resolvió que era improcedente el amparo solicitado, pues existían otros mecanismo judiciales a los cuales podía acudir en tanto que el acto administrativo se encontraba revestido de presunción de legalidad.

La corte constitucional resolvió revocar dicha decisión y como consecuencia ordenarle a la demandada motivar la decisión por la cual resolvió declarar insubsistente a la accionante, indicó que si bien la desvinculación de los empleados vinculados bajo la modalidad de libre 
nombramiento y remoción en tanto que el nombramiento se da por razones personales o de confianza, no se puede dar el mismo tratamiento a los nombrados en provisionalidad en cargos de carrera administrativa, en tanto que los actos que declaran su insubsistencia si deben motivarse.

Que la falta de motivación de los mismos, es una omisión y va en contravía del derecho en tanto que la motivación es indispensable para que proceda la revisión por parte de la jurisdicción contenciosa administrativa, el no hacerlo también produce una especie de indefensión de la persona frente al estado vulnerándoles de esta forma sus garantías constitucionales.

Se observa en los fallos reseñados anteriormente que a las mujeres vinculadas en provisionalidad a las entidades en mención, les fueron garantizados sus derechos fundamentales al debido proceso y el derecho a la defensa al no haberse motivado el acto administrativo que declaraba su insubsistencia por razones de mejorar el servicio pero también fue tenida en cuenta su condición de madres cabeza de familia así como los derechos de sus hijos menores.

Por otro lado, el Consejo de Estado, en Sentencia proferida el 13 de Marzo de 2003, indicó que dada la naturaleza excepcional de la provisionalidad, no existe ningún derecho adquirido y la Providencia del 4 de agosto de 2010 M.P Dr. Gustavo Gómez Aranguren en la Sentencia del 10 de noviembre de 2010, en la cual se estableció que la no exigencia de la motivación del acto de desvinculación del funcionario provisional encuentra su excepción en el Decreto 1227 de 2005, reglamentado por la Ley 909 de 2004 solo cuando el nombramiento provisional se da por terminado antes de cumplirse el término, evento en el que se requiere la motivación del acto administrativo. 


\section{Capítulo 4. Diagnóstico general}

\section{Diagnóstico final}

En los capítulos anteriores de este trabajo de investigación, se estudiaron el sistema de la meritocracia frente a la figura de la provisionalidad en Colombia, los fundamentos jurídicos de la provisionalidad en el ordenamiento jurídico, la estabilidad reforzada, los actos administrativos que declaran la insubsistencia, las posiciones del Consejo de Estado y de la Corte Constitucional frente a la provisionalidad, la mujer cabeza de familia en Colombia y su vinculación excepcional a cargos del Estado, la protección especial que el estado debe brindarles, la acción de tutela como mecanismo principal para obtener el reintegro en sus cargos, así como los derechos económicos de las mujeres. En este capítulo se realizará un diagnostico general en donde se establecerá, luego del desarrollo de la investigación, las situaciones y condiciones en las que se encuentra el grupo que seleccionado para la elaboración de la investigación (mujeres cabeza de familia).

Se establecerá su posición frente al ordenamiento jurídico, pero especialmente respecto de su vinculación excepcional en cargos del Estado, para finalmente proponer soluciones que pudieran conllevar a la toma de decisiones frente al tema que es sin duda importante, coyuntural y que en el evento de no resolverse definitivamente acarreará la vulneración de derechos fundamentales y el desconocimiento de un mandato constitucional como es el concurso de méritos.

Si bien la Constitución Política de Colombia de 1991 dispone la carrera administrativa como regla general para la vinculación a cualquier entidad del Estado, se observa en la actualidad que la figura de la provisionalidad, a pesar de contemplarse como una excepción a dicha regla, ha sido 
utilizada de manera continua por las entidades bajo el argumento de que es necesario garantizar la prestación del servicio mientras se surte el correspondiente concurso de méritos.

Este proceso, por lo general se prolonga en el tiempo, más aún cuando los aspirantes al cargo plantean una serie de oposiciones al procedimiento y a las decisiones, no quedándole otro camino a la convocante que resolver las solicitudes para garantizarles a los concursantes sus derechos constitucionales y fundamentales.

Según el trabajo de investigación titulado La meritocracia en Colombia frente al nombramiento en provisionalidad realizado por Quintero (2014), cuando la Corte Constitucional declaró la inexequibilidad de la conformación de la Comisión de Servicio Civil, los nombramientos provisionales se incrementaron ostensiblemente, es decir que esta ya es una responsabilidad que se deriva del Estado, pues es este el que tiene la obligación a través de la entidad correspondiente de garantizar que el concurso de méritos sea la forma en que se vinculen los servidores del Estado.

Aunque existe discrecionalidad por parte del nominador a la hora de decidir el retiro de un empleado vinculado de manera especial, sus retiros deben cumplir con la debida motivación del acto administrativo para evitar la desviación del poder, demostrando allí el mejoramiento del servicio.

Existe responsabilidad del Estado en el problema planteado pues a pesar de que por orden constitucional se ha ordenado la provisión de cargos públicos mediante el concurso de méritos, se han vinculado al Estado un número considerable de personas mediante la figura excepcional y además le h reconocido a un grupo de personas entre ellas a las mujeres cabeza de familia por ende a su núcleo familiar una protección excepcional, contradicciones que no le permitirán declarar la insubsistencia de las mismas sin soportar unas consecuencias jurídicas y pecuniarias. 
Es evidente la responsabilidad del Estado en el caso en concreto que a pesar de la regla de carácter constitucional (sistema de méritos) que este ha dotado a los involucrados de unos mecanismos que le han permitido y le permitirán defenderse de una eventual declaratoria de insubsistencia entre estos mecanismos se encuentran las leyes, pronunciamientos jurisprudenciales, la acción de tutela, la obligación de motivar el acto administrativo que declara la insubsistencia, la acción de nulidad y restablecimiento del derecho y posiblemente las acciones internacionales que le competen a la Corte Interamericana de Derechos Humanos.

Considerando la segunda parte del trabajo de investigación, se encuentra que el Estado ha denominado a la mujer y por aplicación del derecho a la igualdad hombre cabeza de familia como de protección especial y constitucional del Estado, no pudiendo ser la excepción aquellos que se encuentran vinculados de manera provisional a cargos de carrera administrativa, en tanto que dicha protección no excluye taxativamente a los empleados provisionales de dicha protección, pues de ser ello así, sí existiría un desconocimiento a sus derechos fundamentales especialmente a la igualdad.

No obstante, los nominadores a la hora de declarar la insubsistencia no han realizado el ejercicio de ponderación, por lo que los involucrados han tenido que acudir a la acción de tutela para sostenerse en sus cargos, claro está, teniendo la obligación de acreditar la condición de madres y padres cabeza de familia y en el caso en que no se demuestre tal condición pues la acción de tutela no prosperará.

Se observa que a pesar de que el Estado se ha esforzado para que la población o grupos que se encuentren en desventaja frente a las otras personas, bajo el cumplimiento de unos parámetros legales preestablecidos, gocen de una protección constitucional, entre otros, las madres, padres cabeza de familia y ahora el concepto más amplio mujeres cabeza de familia definidas por la Ley. 
El Estado, al haber vinculado a estas personas que tienen a su cargo un núcleo familiar bajo una modalidad que no les otorga una estabilidad laboral, no sólo ha desconocido el lineamiento constitucional que indica que las personas que ejercen cargos públicos deben superar el sistema de méritos, sino que además, en el momento que se agoten los correspondientes concursos, en el caso que suceda, se generaría un desconocimiento pleno a varios derechos fundamentales y económicos de personas que se encuentran en desventaja por su vulnerabilidad, generando a su vez una avalancha de necesidades para niños, adolescentes en preparación académica, ancianos, personas con discapacidad.

Así las cosas, inminentemente se desconocerían derechos fundamentales y económicos, por lo que el Estado deberá ponderar lo derechos de los involucrados. Resulta necesario que se adopte un proceso especial que defina la situación de dicho grupo y de los demás que gozan de protección especial, ya sea para lograr la inscripción automática pues no se puede desconocer que dichas personas que se han desempeñado en cargos de carrera administrativa en la modalidad de provisionalidad, gozan de una experiencia que debe ser superada por los aspirantes a obtener el cargo de carrera, o que en el evento en que en definitiva sean declarados insubsistentes se garantice que el empleado y su núcleo familiar obtengan una serie de beneficios que les garantice el sustento del hogar, la educación y la salud.

El problema cada vez se hace más notorio, pues a pesar de las fallidas iniciativas legislativas el Estado no ha adoptado una posición determinante en el tema, por lo que se continúa vinculando a personas bajo la modalidad de la provisionalidad. Tampoco ha brindado una solución definitiva a los casos que vienen de muchos años atrás, siendo necesaria una medida definitiva que no perjudique a las personas con protección especial de Estado, más aún cuando ha sido el mismo quien ha provocado dicha disyuntiva entre los lineamientos descritos en la Constitución. 
Vale la pena decir que desafortunadamente, los nominadores frente a la necesidad de motivar los actos administrativos que declaran la insubsistencia y que consideran bien sea por conveniencia, es decir para permitir el ingreso de otras personas de su confianza sin que muchas veces se evalúe si con dicho nombramiento se garantiza un mejoramiento en la prestación del servicio o por decisiones de carácter político en tanto que para garantizar la continuidad en el poder ofrecen cargos a través de la vinculación excepcional para recibir a cambio apoyo político, lo que permite que esta modalidad de vinculación permita actos desconocedores de la ley y de la ética que debe imperar en cualquier actuación en la que tenga que ver con el Estado.

Cuando no se logra la declaratoria de insubsistencia en tanto que el acto administrativo debe ser debidamente motivado so pena de incurrir en las causales de nulidad se ha optado por instaurar quejas disciplinarias para que los vinculados en provisionalidad sean sancionados y como consecuencia sean retirados del servicio para que de esta manera sea posible la vinculación provisional de otra persona.

Según Valdés (2009) indica que [La] provisionalidad se ha terminado por convertir en el caballo de batalla de la burocracia de las entidades públicas en Colombia y que entonces se encuentra que los despachos judiciales se colman de acciones de nulidad y restablecimiento del derecho, “casualmente" dentro de los 4 meses siguientes a los cambios de la administración dentro de una entidad pública como la Alcaldía, la Gobernación o Empresas Sociales del Estado , etc.(p.148).

Continuo indicando Valdés (2009) que se da en forma paradójica una univocidad de argumentos y consideraciones en los actos de insubsistencia, que parecieran ser minutas socializadas en todas las entidades, en las que hasta las citas jurisprudenciales son idénticas, pero 
que en el fondo apuntan a razones partidistas que fundamentan las numerosas desvinculaciones; lo cual es difícilmente demostrable mediante un acervo probatorio, porque como ya se dijo: la entidad demandada, o sea, el empleador, llega al proceso en posición de superioridad frente al empleado demandante. (p.149).

Sin embargo hay un caso en particular en el que el Consejo de Estado Sala de lo Contencioso Administrativo Sección Segunda Subsección A, Consejero Ponente Alfonso Vargas Rincon, tuvo conocimiento del caso en concreto de la señora Gabriela Carranza de Rincón, quien fue nombrada mediante Resolución No. 01290 del 25 de octubre de 1995 como Jefe Grado 06 de la División de Desarrollo Empresarial, tomando posesión el 30 de octubre de 1995, que durante su permanencia en el SENA se destacó por su prestación oportuna y efectiva del servicio, con la entrada de un nuevo Director Regional de Bogotá, mediante acto administrativo N0. 0059 del 30 de mayo de 2001 fue declarada insubsistente.

La señora Carranza de Rincon interpuso demanda de acción de nulidad y restablecimiento del derecho alegando principalmente la causal de desviación de poder. El Tribunal Administrativo de Cundinamarca accedió a las pretensiones encontrando probado el cargo de desviación de poder en tanto que los fines de la declaratoria de insubsistencia no estuvieron dirigidos a mejorar la prestación del servicio sino a la retaliación por su posición contra la vinculación en masa con fines "politiqueros" y que la persona designada para ejercer el cargo no cumplía el requisito de experiencia especifica exigida para el cargo. La decisión fue apelada por el SENA, por lo que el Consejo de Estado tuvo conocimiento del caso en concreto confirmando el fallo bajo los siguientes argumentos: 
- Que de la prueba documental y testimonial la sala se convenció que la demandante desempeñaba sus funciones con rectitud y eficiencia con las que debe ejercer su cargo un servidor público para efectos de garantizar un adecuada prestación del servicio público.

-Que el servicio que prestaba era excelente y superaba las expectativas a pesar de no contar con los recursos suficientes, por lo tanto las capacidades que debían ser demostradas por quien entraría a reemplazarla debían ser superiores.

-Que la entidad demandada debía motivar adecuadamente las razones que fundaron la declaratoria de insubsistencia, sin embargo el acto administrativo indicaba simplemente que la decisión se adoptada bajo la facultad discrecional por lo que no le fue posible demostrar que la insubsistencia había sido declarada con el fin de mejorar la prestación del servicio, por lo que se consideró que la decisión había sido arbitraria configurándose así la causal de nulidad denominada desviación del poder.

\section{Consecuencias legales y sociales de la declaratoria de insubsistencia de las mujeres cabeza de familia que se encuentran vinculadas al Estado en provisionalidad}

Si bien el Estado propende porque la mujer (hombre) cabeza de familia goce de una estabilidad económica que le permita a su familia subsistir, con la declaratoria de insubsistencia de quienes fueron vinculados en provisionalidad, se ha causado importantes agravios no solo a este grupo de personas sino también al Estado, pues en su afán de garantizar la prestación del servicio en las 
diferentes entidades que lo conforman y sin que fuera posible realizar los concursos de méritos, se ha vinculado de manera indiscriminada y sin control a personas bajo esta modalidad.

Anteriormente, cuando no se había decantado el tema en las altas cortes, el nominador, bajo el entendido de que la provisionalidad se equiparaba al de libre nombramiento y remoción, profería el acto de insubsistencia sin motivarlo, desvinculando de esta manera a personas sin permitirles ejercer su derecho al debido proceso.

Posteriormente, al considerar a la Corte Constitucional, amparada en el derecho fundamental al Debido Proceso, los actos de declaratoria de insubsistencia debían ser debidamente motivados, principalmente demostrando el mejoramiento del servicio, aspecto en estos casos difícil de demostrar dado que por lo general las personas vinculadas bajo dicha modalidad se encuentran ejerciendo dichos cargos hace bastante tiempo. Razón por la cual, a pesar de la preparación académica que puedan tener los aspirantes a ocupar el cargo en carrera administrativa, no poseerían la experiencia con la que sí cuentan las personas que se encuentran ocupando el cargo en provisionalidad, que han asistido a capacitaciones y que conocen a profundidad cada uno de los temas que se adelantan en las diferentes entidades estatales en donde se desempeñan como servidores públicos.

De tal manera, al no ser posible la debida motivación bajo el argumento del mejoramiento del servicio, puesto que se incurre en desviación del poder, muchas de las personas declaradas insubsistentes presentaron demandas en contra del Estado a través de la acción de nulidad y restablecimiento del derecho, en donde al no existir una fundamentación adecuada en el correspondiente acto administrativo han sido incorporados a sus cargos, reconociéndoles además los sueldos y prestaciones dejados de percibir hasta el momento de su reintegro al cargo; claro está 
que con la condición de que se desempeñarán allí hasta tanto no se surta el proceso correspondiente para proveer los cargos en carrera administrativa.

Las diferentes declaraciones y condenas que se han fallado por vía de tutela o en acción de nulidad y restablecimiento del derecho, han obligado al Estado no solo a reintegrar a los accionantes, sino también a reconocerles considerables sumas de dinero causándole al Estado un detrimento patrimonial al tener que pagar condenas exorbitantes y como consecuencia iniciar la correspondiente acción de repetición ${ }^{33}$ en contra del funcionario que en ejercicio de una desviación de poder, resolvió declarar la insubsistencia sin motivar el acto administrativo o al haberlo motivado no se haga debidamente bajo los presupuestos legales correspondientes.

Ahora bien, cuando en su momento se adelanten los concursos para proveer los cargos en carrera administrativa ocupados por las mujeres (hombres) cabeza de familia y se declare su insubsistencia, se vulnerarán a la mujer u hombre y su grupo familiar, los derechos a la no discriminación e igualdad, el derecho al trabajo, a la salud y la seguridad social, a la propiedad, a la vivienda, entre otros, como se evidencia en el análisis jurídico que se realizó en el trabajo de investigación, en tanto que la mujer u hombre cabeza de familia no percibiría la remuneración económica que le permitirá solventar las necesidades básicas de su grupo familiar.

Además de lo anterior, con la declaratoria indiscriminada de insubsistencia, el Estado les ocasionaría a las mujeres y hombres cabeza de familia un daño antijurídico, al no ejercer la adecuada administración que evitara causarlo, sobre todo en nombre del Estado Social de Derecho

\footnotetext{
${ }^{33}$ Conforme al artículo 77 del Decreto 01 de 1984, los funcionario deben responder por los daños causados por culpa grave o dolo en ejercicio de sus funciones sin perjuicio de la responsabilidad de la Nación y de las entidades territoriales, descentralizadas o privadas que cumplen funciones públicas las que de prosperar la demandan repetirán contra el funcionario por lo que correspondiere. La acción de repetición prosperará cuando: Exista una condena contra el Estado por daños imputables a la acción u omisión de alguna autoridad, que la entidad que haya sido condenada haya pagado las declaraciones y condenadas en la sentencia, que se demuestre el actuar gravemente culposo o doloso del servidor o ex servidor (nominador) que declaró la insubsistencia.
} 
colombiano, el cual garantiza la salvaguarda de los derechos de sus asociados; más aún cuando dicho grupo, como se indicó en el capítulo correspondiente, goza de una protección constitucional y se extiende a todo su grupo núcleo familiar, una vez decicido de fondo el problema en el evento de declarar la insubsistencia de manera masiva, dichas personas podrán acudir a la Corte Interamericana de Derechos Humanos en donde lo más posible es que obtengan una decisión favorable a ellas que le implique al Estado colombiano sanciones y el reconocimiento de indemnizaciones.

Como se ha indicado en varias oportunidades han existido varias iniciativas legislativas para darle solución a un problema que es latente y que en cualquier momento desencadenará una serie de actuaciones por parte del Estado que pueden acarrear graves consecuencias sociales y económicas para este grupo de personas, y que terminará en el desconocimiento pleno de derechos fundamentales de un grupo de personas que han sido catalogadas como vulnerables.

A pesar de que se puede pensar que la solución está en cabeza del legislador, no es menos cierto que también se trata de un tema de ponderación de derechos, pues por un lado se encuentra la disposición constitucional que ordena la provisión de cargos a través del concurso de méritos, pero por otro lado también se encuentran los derechos fundamentales y económicos de un grupo que goza de protección especial y constitucional por parte del Estado.

Por lo general, en cualquier ordenamiento jurídico se le ha impuesto a los jueces la función de argumentar sus decisiones, en virtud de que se les ha encomendado la misión de administrar justicia, por lo que se les ha investido de una facultad discrecionalidad o de ponderación, la cual se encuentra bajo el sofisma de la libertad para proferir sus decisiones; pero a la vez se reconoce la sujeción de las mismas al ordenamiento que los rige. A pesar de que se le otorga la posibilidad al juez de perfilar sus decisiones desde el carácter de la discrecionalidad, ello no es óbice para que 
estas decaigan en la arbitrariedad (antivalor judicial), en tanto que al traspasarse la delgada línea de su función los jueces incurrirían en el delito de prevaricato.

Lo anterior, para indicar que la discrecionalidad es "aquella decisión en que se opta libremente entre alternativas, pero con arreglo a un modelo o ideal normativo que permite enjuiciar positiva y negativamente dicha elección en sí libre” (García, 2010, párr. 8), es decir que se le otorga al administrador de justicia la posibilidad de proferir sus decisiones libremente; podría decirse bajo el enfoque subjetivo que predomine en su formación bien sea de carácter teológico, económico etc.; pero a la vez se encuentra sometido al engranaje jurídico preestablecido (principio de legalidad $)^{34}$. Lo que se pretendería con ello en principio es que los fallos judiciales se produzcan por parte de sus autores desde el tópico de la objetividad, sin dejar de desconocer que existen inevitablemente unos componentes de carácter subjetivo que le permitirán al juzgador acceder a varias posibilidades respecto de la norma y su interpretación.

No se le puede atribuir exclusivamente a las normas ya preestablecidas la responsabilidad absoluta en la situación planteada, tampoco al Estado en lo que tiene que ver a la omisión de cumplir el mandato constitucional de surtir los concursos de méritos. El asunto también le incumbe la administración de justicia, en tanto que son los jueces quienes finalmente tienen a su cargo dirimir los casos en concreto presentados por las mujeres y hombres cabeza de familia declaradas insubsistencia que acuden a la justicia buscando protección. Por esta razón los servidores deben encontrarse debidamente preparados para adoptar decisiones judiciales correspondientes o de otra índole, es decir que no solo deben aplicar la normatividad aplicable, sino que deben poseer las aptitudes suficientes que les permitir realizar adecuadamente los juicios de valor, siempre

\footnotetext{
${ }^{34}$ El principio de legalidad definido como la aplicación de las consecuencias que la norma ha dispuesto.
} 
atendiendo la voluntad expresada por el legislador el cual dispone en la misma quién es el vencedor en el litigio, claro está, luego de analizar los principios en confrontación y establecer cual debe predominar. Asimismo es importante la correspondiente distribución de competencias al interior de las organizaciones conformadas para efectos de que las decisiones judiciales provengan del funcionario que dispuso la norma.

Ahora bien, en la práctica y la doctrina, la ponderación y la subsunción son determinantes en el momento de adoptar una decisión que sin lugar a dudas producirá unos efectos jurídicos para los involucrados y su entorno, sin embargo de lo planteado por García (2010), se observa que son definidos como métodos, sin que el autor profundice si efectivamente pueden denominarse como tal o simplemente, se trata de procedimientos de razonamiento judicial o justificación de decisiones judiciales.

Se dice que en el momento en que el juez realiza el correspondiente ejercicio de la ponderación bajo las circunstancias fácticas y el caso sub judice que se le pone de presente inevitablemente, si se realiza adecuadamente saldrán a la luz los principios que se contraponen siempre, arrojando como resultado sin mayor esfuerzo el principio vencedor que de una u otra manera el legislador consideró debía imperar.

En cuanto a la subsunción se dice que es aquel método en el cual los hechos y las circunstancias presentadas se encajan en los presupuestos ya establecidos, se habla de un procedimiento mecánico que no admite mayor ponderación o interpretación en lo que tiene que ver con la regla general o la abstracta que se considera es aplicable; es decir que para el positivismo es imperiosa la precisión de la norma y para los ponderadores la precisión de los hechos, para que de dicho juicio se produzca la norma aplicable al caso y el principio vencedor. 
A nivel internacional se destaca el caso de España, donde según García (2010) se presenta con frecuencia que el Tribunal Constitucional anula decisiones del Tribunal Supremo cuando la confrontación se origina de derechos fundamentales, considerando que este último no ha realizado adecuadamente el trabajo de ponderación, pero refiere el autor que el Tribunal Constitucional en ocasiones hace caso omiso a la adecuada ponderación y adopta fallos similares a los que cuestiona, de lo cual podría pensarse que aún los funcionarios no atienden dicho método en todas sus decisiones por lo menos en España

De acuerdo a la doctrina del Tribunal Constitucional (Sentencia 186 de 2000; TRC 2000,186), la constitucionalidad de cualquier medida restrictiva de derechos fundamentales deviene de la observancia estricta al principio de proporcionalidad, en otras palabras que para determinar dicha proporcionalidad según la STC 186 de 2000 ha de tenerse en cuenta tres requisitos primordiales a saber:

El juicio de idoneidad. La determinación de la idoneidad, la necesidad de establecer que no existe otra medida adecuada que pueda lograr el propósito de la misma , así como la eficacia, pero hay que tener en cuenta que en este paso el juez debe argumentar las razones por las cuales considera que ninguna otra medida es más indicada de la que está imponiendo luego de haber realizado el correspondiente análisis de razonabilidad, (el juicio de proporcionalidad en sentido estricto), es decir que aquí se establece si la medida es ponderada y con ello se obtienen los beneficios y si se garantizan realmente los intereses generales de la comunidad.

En el juicio de proporcionalidad se dirimen los conflictos que surgen entre derechos fundamentales, allí se determinará el grado de afectación positiva o negativa de uno de los derechos fundamentales confrontados, es decir que el juzgador le atribuirá el valor que considera desde su facultad legal discrecional. 
Habiéndose resumido la forma en que se producen las decisiones en los tribunales españoles, donde en todas sus jurisdicciones incluyendo la civil, se realiza el correspondiente test de proporcionalidad a pesar de que en el ordenamiento jurídico colombiano tímidamente se hace mención al test de proporcionalidad que deben realizar los jueces en cada una de sus decisiones para efectos de establecer la proporcionalidad de la misma; es decir que estas deben cumplir con unos requisitos constitucionales y legales, que dicha proporcionalidad busca garantizar el cumplimiento de los fines constitucionales y determinar si estos deben ceder a los derechos individuales que se contraponen con el litigio. Se debe determinar la idoneidad de la decisión que persigue el cumplimiento de cualquier garantía constitucional, la necesidad y la proporcionalidad en sentido estricto.

Según Vásquez (2009), indicó que tal como lo afirman los profesores Bernal Pulido y Suarez Varòn, en estudio a los precedentes jurisprudenciales de la Corte Constitucional, permite dar cuenta que dicha Corporación Judicial ha establecido diversos criterios para aplicar el derecho a la igualdad y que sin embargo el juicio de proporcionalidad europeo tiene la ventaja de aclarar los pasos que deben realizarse en el control abstracto de la ley, pero tiene en contra que el mismo se lleva a cabo en todos los casos (p.100).

Puntualizó Vásquez (2009), que la Corte Constitucional Colombiana dentro de las metodologías empleadas para la resolución de casos en los que se envuelven en situaciones relativas a la igualdad, ha venido utilizando diversos test, escrutinios o juicios dentro de su proceso de decantamiento judicial, creando una simbiosis entre el método europeo y americano, que se conoce en la dogmática constitucional local como "Juicio Integrado o Mixto de Igualdad". (p.101)

Así las cosas, se ha evidenciado con el trabajo de investigación un problema latente que en determinado momento debe ser afrontado por el Estado y adoptar las correspondientes decisiones 
de fondo, para ello deberá realizar el ejercicio de ponderación por un lado la obligatoriedad de rango constitucional en la que los funcionarios que ocupen cargos del Estado deben superar el sistema de mérito y por otro lado, los derechos de la mujer u hombre cabeza de familia y su núcleo familiar quienes ingresaron a través de la vinculación excepcional y que ya llevan bastantes años en dicha condición. 


\section{Conclusiones y recomendaciones.}

Realizado el trabajo de investigación en donde se analizó el sistema de la meritocracia en Colombia, la provisionalidad como regla excepcional de vinculación a cargos del Estado, la vinculación de mujeres y hombres cabeza de familia bajo esta modalidad que gozan de protección constitucional, frente al problema planteado es decir el de determinar si al declararse la insubsistencia de una mujer u hombre cabeza de familia a raíz de un concurso de méritos para proveer un cargo de carrera administrativa al cual se encontraba vinculada en provisionalidad, se produce o no una afectación injustificada de sus derechos fundamentales, así como los de su núcleo familiar y que en el evento de verificarse dicha afectación en este caso se presentarían posibilidades o alternativas de solución, la investigadora presenta las siguientes conclusiones y recomendaciones.

- El concurso de méritos desde antes de la constitución de 1991 ya había sido dispuesto como la forma idónea de proveer los cargos que se encuentran contemplados como de carrera administrativa, sin embargo, fue después de su promulgación que se reconoció la importancia de implementarla en el Estado Social, Pluralista y Democrático de Derecho colombiano; no solo para garantizar la adecuada prestación del servicio público, sino también para asegurarle 
a los servidores que cumplen funciones públicas derechos importantes como el de la estabilidad laboral.

- Se evidencia que a pesar de lo dispuesto en el artículo 123 de la Constitución Política de Colombia de 1991, el cual dispone el concurso de méritos como de obligatorio cumplimiento, el mismo Estado no ha dado cabal cumplimento a dicho precepto, bien sea por falta de recursos o por conveniencia. Esta situación ha generado que la figura excepcional de la provisionalidad haya adquirido un rol importante en la prestación del servicio que garantiza el Estado, por ende es necesario buscar una solución que evite el impacto que originaría el hecho de declarar la insubsistencia de personas que gozan de protección especial como las madres y padres cabeza de familia, más aún cuando se ha promulgado el Decreto 051 de 2018 mediante el cual se reitera el deber de las entidades de orden nacional de apropiar el monto de los recursos y las entidades de orden territorial priorizar el gasto con el fin de adelantar los concursos de méritos abierto

- La ineficacia del Estado frente a la obligación de realizar los respectivos concursos de méritos ha generado la permanencia de empleados públicos bajo la figura de la provisionalidad otorgándoles una estabilidad reforzada.

- El Estado les ha otorgado a los empleados vinculados en provisionalidad a cargos públicos, entre ellos madres y padres cabeza de familia mecanismos que les permiten mantenerse en sus cargos, entre otras normas como la ley 909 de 2004 y la 790 de 2002 que protegen su condición, los pronunciamientos de las Cortes, los intentos legislativos, la acción de tutela, la acción y nulidad del restablecimiento del derecho y la posibilidad en el evento de producirse una decisión de fondo frente al caso en concreto de acceder a acciones internacionales ante la Corte Interamericana de Derechos Humanos. 
- Existe una confrontación entre la obligación constitucional de proveer los cargos públicos del Estado mediante el concurso de méritos y los derechos fundamentales y constitucionales de los vinculados en provisionalidad, situación que produjo un "choque de trenes" entre la Corte Constitucional (conocimiento iusfundamentalista) y el Consejo de Estado (juez natural). La primera indicaba que a pesar de la facultad discrecional del nominador debe garantizarse los derechos fundamentales al Debido Proceso y de Defensa, y que por lo tanto debía motivarse el acto administrativo que la declara. Y la segunda consideraba inicialmente que no había obligación de su motivación en tanto que se equiparaba con los cargos de libre nombramiento y remoción, finalmente luego de varias acciones tutelas, en la actualidad predomina la obligación de motivar los actos administrativos que declaran la insubsistencia, la cual permite la permanencia en los cargos de los empleados vinculados en provisionalidad.

- A pesar de que la responsabilidad de que el concurso de méritos no se haya agotado integralmente, es del Estado. Tampoco puede dejarse de lado que no es procedente que en ejercicio del derecho al debido proceso de defensa, al trabajo a la dignidad humana de los vinculados en provisionalidad, se cree automáticamente una estabilidad laboral reforzada, que a la postre se convertirá en un problema en tanto que cuando el Estado pretenda ejercer su facultad discrecional los involucrados podrán demandar y obtener considerables sumas de dinero que causarán un grave detrimento patrimonial al Estado.

- A pesar de que en principio en la constitución se pretendió excepcionalmente proteger a la mujer cabeza de familia en ocasión a una realidad conocida y aceptada por la sociedad como lo es la desigualdad y discriminación de la mujer frente al Estado y los asociados, el concepto se extendió al hombre cabeza de familia siempre y cuando reúna los requisitos legales para adquirir tal condición. 
- Con la inminente declaratoria de insubsistencia de mujeres y hombres cabeza de familia, además de desconocerse derechos fundamentales a dichas personas y su grupo familiar, se desconocerían derechos económicos; razón por la cual es necesario que el Estado adopte una decisión definitiva que solucione las condiciones de las personas que se encuentran en tal condición y que en adelante ejecute el sistema de méritos como forma de vinculación al Estado.

- Las decisiones que se adopten sobre el tema deben ser el producto del trabajo del legislador y de los jueces que deben intervenir en las acciones y demandas masivas que eventualmente puedan presentarse en una inminente declaratoria de insubsistencia que afectaría ostensiblemente derechos fundamentales de un grupo considerable de personas con protección especial por parte del Estado, hecho por el que existiría una contradicción de lo que se ha planteado como Estado Social de Derecho.

A partir de las anteriores conclusiones es posible formular las siguientes recomendaciones:

En primer lugar, teniendo en cuenta que se trata de una situación generada por el mismo Estado, podría ser procedente la inscripción automática de las personas que gozan de protección especial y constitucional por parte del Estado, a través del legislativo, bajo el cumplimiento de unos parámetros; los cuales serán adoptados luego de un estudio profundo de estadísticas y de las condiciones que gozan de protección especial, para posteriormente empezar a materializar el sistema de méritos como regla general para proveer cargos públicos.

Adicionalmente, realizar por parte de los jueces que puedan tener injerencia o conocimiento en dichos casos un análisis de ponderación de derechos, se necesita de un ejercicio y análisis 
concienzudo de los jueces constitucionales para que luego el legislador pueda materializar la conclusión del ejercicio.

Otro camino es que se declare la insubsistencia de todas las personas que se encuentren vinculados a cargos del Estado una vez se surta el correspondiente concurso, no obstante el Estado deberá adoptar una serie de medidas que garanticen los derechos en este caso de las mujeres (hombres) cabeza de familia, ya sea a través del reconocimiento de indemnizaciones, subsidio de estudio para los hijos y para ella (el) misma, garantizar la salud etc.; es decir la implementación de acciones afirmativas las cuales mitigarán el daño antijurídico que se genere con la desvinculación del Estado y de esta manea se estaría cumpliendo a cabalidad con la obligación de que se surta el concurso de méritos y por otro lado, hacer efectivas las garantías constitucionales dispuestas para la mujer (hombre) cabeza de familia, por ende a todo su núcleo familiar.

El Estado colombiano puede acudir a la Corte Interamericana de Derechos Humanos en ejercicio de la actividad consultiva para poner en su conocimiento el caso en concreto para efectos de establecer si en el evento de declararse la insubsistencia de este grupo vulnerable se produciría una vulneración a derechos humanos y derechos económicos de esta manera el Estado Colombiano puede saber con anterioridad de las consecuencias que acarrearían tal decisión o que la Comisión Interamericana de Derechos Humanos pudiera formular algunas recomendaciones, para evitar eventuales sanciones sociales y económicas. 


\section{Referencias}

Acosta, P. (2007). Protección de los Derechos de las Mujeres en la Constitución Colombiana. Revista Derecho del Estado. (20), 49-60.

Alta Consejería Presidencial para la Equidad de la Mujer. (2011). Boletín 13. La participación política de las mujeres en Colombia: Avances, retos y análisis sobre la presencia y acceso de las mujeres a los espacios de decisión en el país. Bogotá, D.C.: Observatorio de Asuntos de Género.

Álzate, R. (2011). Derecho administrativo colombiano. Bogotá, D.C.: Volumen III.

Arango, M. (2004). El bloque de constitucionalidad en la jusrisprudencia de la corte constitucional colombiana. Cali: Universidad Icesi.

Asamblea General de la ONU. (1966). Resolución 2200 A (XXI) del 16 de diciembre de 1966. [Pacto internacional de derechos civiles y políticos]. Nueva York, Estados unidos.

Asamblea General de la ONU. (1966). Resolución 2200 A (XXI) del 16 de diciembre de 1966. [Pacto Internacional de Derechos Económicos, Sociales y Culturales.]. Nueva York, Estados Unidos.

Asamblea General de la ONU. (1971). Declaración de los Derechos del Deficiente Mental del 20 de diciembre de 1971. Nueva York, Estados Unidos. 
Asamblea General de la ONU. (1975). Resolución 3447 del 9 de diciembre de 1975.

[Declaración de los Derechos de los Impedidos.]. Nueva York, Estados Unidos.

Asamblea General de las Naciones Unidas . (1993). Resolución 48/96 del 20 de diciembre de 1993.

[Sobre las Normas uniformes sobre la igualdad de oportunidades para las personas con discapacidad.]. Nueva York, Estados Unidos.

Asamblea Nacional Constituyente de la República de Colombia. (1991). Constitución Política de Colombia del 4 de julio de 1991. Bogotá, D.C., Colombia.

Ayestaran, K. (2011). Investigación jurídica. Obtenido de Derecho : http://www.monografias.com/trabajos85/derecho-investigacionjuridica/derechoinvestigacion-juridica.shtml

Bernal, F. (2010). Derecho Administrativo. Informe de caracterización del Empleo público en Colombia. Bogotá, D.C.: Escuela Superior de Administración Publica Colombia.

Informe (2017), Ocho competencias laborales que practican mamás en casa, Univesidad de la Sabana, Bogotá D.c.

ELCA (2017) Encuesta longitudinal Colombiana Universidad de los Andes, Bogotá D.C.

Botero, C. (s.f.). La acción de tutela en el ordenamiento constitucional colombiano.

Bucaramanga: Uniciencias.

Castro, J. (2008). La naturaleza jurídica del servidor público. Bogotá, D.C.: Capítulo III.

CLAD. (2004 ). IX Congreso Internacional del CLAD sobre la Reforma del Estado y de la Administración Pública. Madrid: CLAD.

Conferencia Intergubernamental Iberoamérica. (1992 ). Declaración de Cartagena de Indias del 30 de octubre de 1992 [Sobre políticas integrales para las personas con discapacidad en el área iberoamericana.]. Cartagena de Indias, Colombia. 
Congreso de la República de Colombia . (2011). Ley 1434 del 6 de Enero de 2011. [Por la cual se modifica y adiciona la ley 5 de 1992, se crea la comisión legal para la equidad de la mujer del congreso de la República de Colombia y se dictan otras disposiciones.].

Bogotá, D.C., Colombia.

Congreso de la República de Colombia. (1938). Ley 165 del 29 de Octubre de 1938. Diario

Oficial 23357. [Por la cual se crea la carrera administrativa.]. Bogotá, D.C., Colombia.

Congreso de la República de Colombia. (1958). Ley 19 del 18 de Noviembre de 1958. Diario

Oficial No. 29.835. [Sobre reforma administrativa.]. Bogotá, D.C., Colombia.

Congreso de la República de Colombia. (1981). Ley 51 del 2 de Junio de 1981. Diario Oficial 35794 . [Por medio de la cual se aprueba la "Convención sobre la eliminación de todas las formas de discriminación contra la mujer.]. Bogotá, D.C., Colombia.

Congreso de la República de Colombia. (1987 ). Ley 61 del 30 de Diciembre de 1987. Diario Oficial 38171. [Por la cual se expiden normas sobre la Carrera Administrativa y se dictan otras disposiciones.]. Bogotá, D.C. , Colombia.

Congreso de la República de Colombia. (1988). Ley 82 de 1988 del 23 de Diciembre de 1988. Diario Oficial 38626. [Por medio de la cual se aprueba el Convenio 159 sobre la readaptación profesional y el empleo de personas inválidas...]. Bogotá, D.C., Colombia.

Congreso de la República de Colombia. (1992). Ley 27 del 23 de Diciembre de 1992. Diario Oficial 40700. [Por la cual se desarrolla el artículo 125 de la Constitución Política, se expiden normas sobre administración de personal al servicio del Estado, se otorgan unas facultades y ...]. Bogotá, D.C., Colombia. 
Congreso de la República de Colombia. (1993). Ley 82 del 3 de Noviembre de 1993. Diario Oficial 41.101. [Por la cual se expiden normas para apoyar de manera especial a la mujer cabeza de familia.]. Bogotá, D.C., Colombia.

Congreso de la República de Colombia. (1995). Ley 248 del 29 de Diciembre de 1995. [Por medio de la cual se aprueba la Convención Internacional para prevenir, sancionar y erradicar la violencia contra la mujer, suscrita en la ciudad de Belem Do Para, Brasil, el 9 de junio de 1994.]. Bogotá, D.C., Colombia.

Congreso de la República de Colombia . (1997). Ley 361 del 7 de Febrero de 1997. [Por la cual se establecen mecanismos de integración social de la personas con limitación y se dictan otras disposiciones.]. Bogotá, D.C., Colombia .

Congreso de la República de Colombia. (1998). Ley 443 del 11 de Junio de 1998. Diario Oficial 43.320. [Por la cual se expiden normas sobre carrera administrativa y se dictan otras disposiciones.]. Bogotá, D.C., Colombia.

Congreso de la República de Colombia. (2000). Ley 581 del 31 de Mayo de 2000. Diario Oficial 44.026. [Por la cual se reglamenta la adecuada y efectiva participación de la mujer en los niveles decisorios de las diferentes ramas y órganos del poder público...]. Bogotá, D.C., Colombia.

Congreso de la República de Colombia. (2000). Ley 938 del 30 de Diciembre de 2000. Diario Oficial 45.778. [Por la cual se expide el Estatuto Orgánico de la Fiscalía General de la Nación. ]. Bogotá, D.C., Colombia.

Congreso de la República de Colombia. (2002). Ley 790 del 27 de Diciembre de 2002. [Por la cual se expiden disposiciones para adelantar el programa de renovación de la administración 
pública y se otorgan unas facultades extraordinarias al Presidente de la República.]. Bogotá, D.C., Colombia.

Congreso de la República de Colombia. (2003). Ley 823 del 10 Julio de 2003. [Por la cual se dictan normas sobre igualdad de oportunidades para las mujeres.]. Bogotá, D.C., Colombia.

Congreso de la República de Colombia. (2004 ). Ley 909 del 23 de Septiembre de 2004. Diario Oficial 45.680. [Por la cual se expiden normas que regulan el empleo público, la carrera administrativa, gerencia pública y se dictan otras disposiciones.]. Bogotá. D.C., Colombia.

Congreso de la República de Colombia. (2004). Ley 906 del 31 de Agosto de 2004. Diario Oficial 45658. [Por la cual se expide el Código de Procedimiento Penal. (Corregida de conformidad con el Decreto 2770 de 2004)]. Bogotá, D.C., Colombia.

Congreso de la República de Colombia. (2006 ). Ley 1033 del 18 de Julio de 2006. [Por la cual se establece la Carrera Administrativa Especial para los empleados Públicos no uniformados al servicio del Ministerio de Defensa Nacional, de las Fuerzas Militares, de la Policía Nacional y...]. Bogotá, D.C., Colombia.

Congreso de la República de Colombia. (2007). Proyecto de Ley 117 del 4 de septiembre de 2007 Senado. [Por el cual se reforman los artículos $3^{\circ}$ y 31, numeral 5 de la Ley 909 de 2004]. Bogotá, D.C., Colombia.

Congreso de la República de Colombia. (2008). Acta de Conciliación al Proyecto de Ley 117 de 2007 del 3 de Abril de 2008. [Por el cual se reforman algunos artículos de la Ley 909 de 2004, algunos artículos de las disposiciones que contienen los concursos de los sistemas específicos y especiales ... ]. Bogotá, D.C., Colombia. 
Congreso de la República de Colombia. (2008). Acto Legislativo No. 1 del 26 de diciembre de 2008. Diario Oficial 47214. [Declarado INXEQUIBLE por la Corte Constitucional mediante Sentencia C-588 de 2009 .]. Bogotá, D.C., Colombia.

Congreso de la República de Colombia. (2008). Ley 1232 del 17 de Julio de 2008. Diario Oficial 47.053. [Por la cual se modifica la Ley 82 de 1993, Ley Mujer Cabeza de Familia y se dictan otras disposiciones.] 2008. Bogotá, D.C., Colombia.

Congreso de la República de Colombia. (2008). Ley 1257 del 4 de Diciembre de 2008. Diario Oficial 47.193. [Por la cual se dictan normas de sensibilización, prevención y sanción de formas de violencia y discriminación contra las mujeres, se reforman los Códigos Penal, de Procedimiento Penal...]. Bogotá, D.C., Colombia.

Congreso de La República de Colombia. (2011). Ley 1450 del 16 de Junio de 2011. Diario

Oficial 48102. [Por la cual se expide el Plan Nacional de Desarrollo, 2010-2014.]. Bogotá, D.C., Colombia.

Congreso de la República de Colombia. (2011). Ley 1496 del 29 de Diciembre de 2011. [Por medio de la cual se garantiza la igualdad salarial y de retribución laboral entre mujeres y hombres, se establecen mecanismos para erradicar cualquier forma de discriminación y se dictan otras disposiciones.]. Bogotá, D.C., Colombia.

Congreso de la República de Colombia. (2011). Ley Estatutaria 1475 del 14 de Julio de 2011. Diario Oficial 48130. [Por la cual se adoptan reglas de organización y funcionamiento de los partidos y movimientos políticos, de los procesos electorales y se dictan otras disposiciones.]. Bogotá, D.C., Colombia.

Definicion legal. (2012). La Función Pública. Obtenido de Concepto Jurídico: http://definicionlegal.blogspot.com.co/2012/11/la-funcion-publica.html 
Fajardo, C. (2014). Servidores Públicos del Estado con especial protección constitucional.

Políticas de Prevención del Daño Antijurídico en relación con su retiro del servicio. Bogotá D.C.: Universidad del Rosario.

García, J. (2010). Todo lo que usted siempre quiso saber sobre la (teoría de) la argumentación jurídica y nunca se atrevió a preguntar (II). Obtenido de Archivo del blog: http://garciamado.blogspot.com/2010/10/todo-lo-que-usted-siempre-quiso-saber.html

Gómez, G. (2002). Principios del derecho administrativo. Bogotá, D.C.: ABC Editores.

González, E. (2010). Situación del régimen de la carrera administrativa en Colombia. Prolegómenos - Derechos y Valores. XIII (25), 147-163.

Ibáñez, G. (2005). Bases constitucionales de la función pública. Bogotá, D.C.: Ediciones Jurídicas Gustavo Ibáñez.

Marín, H. (2007). Discrecionalidad Administrativa. Bogotá, D.C.: U. Externado de Colombia. Martínez, E. (2010). La carrera administrativa en Colombia: 70 años de ficción. Opinión Jurídica. 9 (18), 107-126.

Medina, J. (2014). Conceptos Indeterminados, Técnica Utilizada por el Legislador para establecer los Empleos de Libre Nombramiento y Remoción. . Bogotá, D.C.: Universidad Pontificia Bolivariana.

Mendoza, J. (2015). Análisis de la situación laboral de los empleados provisionales frente a los empleados de carrera administrativa en estado colombiano. Bogotá, D.C.: Universidad Santo Tomas.

Ministerio de Educación Nacional. (2016 ). Concepto 14651 del 26 de Enero de 2016 [Radicado No.: 20166000014651]. Bogotá D. C., Colombia.

Mora, E., \& Rivera, A. (2002). Derecho administrativo y procesal administrativo, 4ta edición. 
Bogotá, D.C.: Leyer.

Olano, H. (2016). Teoría del órgano manual erudito de derecho administrativo general. Chía:

Universidad de La Sabana.

Organización de los Estados Americanos. (1988). Protocolo Adicional a la Convención

Americana sobre Derechos Humanos en Materia de Derechos Económicos, Sociales y Culturales "Protocolo de San Salvador" del 17 de noviembre de 1988. San Salvador, El Salvador.

Organización Internacional del Trabajo . (1983 ). C159 del 20 de Junio de 1983 [Convenio sobre la readaptación profesional y el empleo de personas inválidas.]. Ginebra, Suiza.

Organización Internacional del Trabajo. (1983). R-168 del 20 de Junio de 1983. [Recomendación sobre la readaptación profesional y el empleo de personas inválidas.]. Ginebra, Suiza.

Ortega, D. (2012). Aportes Jurídicos para una renovación de la carrera Administrativa en Colombia. . Bogotá, D.C.: Universidad Nacional Bogotá.

Peláez, M. (2001). La política de género en el estado colombiano: un camino de conquistas sociales. Rio de Janeiro: Escuela Nacional de Salud Pública.

Pereira, M., \& Carrillo, Y. (2015). Principio de proporcionalidad, argumentación jurídica, y potestad discrecional de la administración pública: Análisis desde los límites a los derechos y garantías fundamentales. San Vicente del Raspeig: Universidad de Alicante.

Presidencia de la República de Colombia. (1886). La Constitución Política de Colombia del 5 de agosto de 1886. Bogotá, D.C., Colombia.

Presidencia de la República de Colombia. (1960). Decreto 1732 del 18 de Julio de 1960. [Sobre Servicio Civil y Carrera Administrativa]. Bogotá, D.C., Colombia. 
Presidencia de la República de Colombia. (1968). Decreto 2400 del 19 de Septiembre de 1968. Diario Oficial 32625. [Por el cual se modifican las normas que regulan la administración del personal civil y se dictan otras disposiciones.]. Bogotá, D.C., Colombia.

Presidencia de la República de Colombia. (1973). Decreto 1950 del 24 de Septiembre de 1973.

Diario Oficial 33962. [Por el cual se reglamentan los Decretos- Leyes 2400 y 3074 de 1968 y otras normas sobre administración del personal civil.]. Bogotá, D.C., Colombia.

Presidencia de la República de Colombia. (1984). Decreto 01 del 2 de Enero de 1984. Diario Oficial 36439. [Por el cual se reforma el Código Contencioso Administrativo.]. Bogotá, D.C., Colombia.

Presidencia de la República de Colombia. (1989). Decreto 2177 del 21 de Septiembre de 1989. Diario Oficial 38991 [Por el cual se desarrolla la ley 82 de 1988, aprobatoria del convenio numero 159, suscrito con la organizacin internacional del trabajo, sobre readaptación profesional y...]. Bogotá, D.C., Colombia.

Presidencia de la República de Colombia. (1991). Decreto 2591 del 19 de Noviembre de 1991. [Por el cual se reglamenta la acción de tutela consagrada en el artículo 86 de la Constitución Política.]. Bogotá, D.C., Colombia.

Presidencia de la República de Colombia. (1998). Decreto 1330 del 13 de Julio de 1998. Diario Oficial 43.340. [Por el cual se reglamenta parcialmente el parágrafo 2 del artículo 15 y el artículo 16 de la Ley 443 de 1998.]. Bogotá, D.C., Colombia.

Presidencia de la República de Colombia. (1998). Decreto 1567 del 5 de Agosto de 1998. [Por el cual se crean (sic) el sistema nacional de capacitación y el sistema de estímulos para los empleados del Estado.]. Bogotá, D.C., Colombia.

Presidencia de la República de Colombia. (1998). Decreto 1572 del 5 de Agosto de 1998. Diario 
Oficial 43.358. [Por el cual se reglamenta la Ley 443 de 1998 y el Decreto - Ley 1567 de 1998.]. Bogotá, D.C., Colombia.

Presidencia de la República de Colombia. (1998). Decreto 1754 del 25 de Agosto de 1998.

Diario Oficial 43.372. [Por el cual se deroga el Decreto 1330 de 1998.]. Bogotá, D.C., Colombia.

Presidencia de la República de Colombia. (1998). Decreto 2504 del 10 de Diciembre de 1998.

Diario Oficial 43.449. [Por el cual se modifican los artículos 2, 4 y 12 (transitorio), 130, 131, 135, 149, 151, 154, 155 y 156 del Decreto 1572 de 1998.]. Bogotá, D.C., Colombia. Presidencia de la República de Colombia. (1999). Decreto 917 del 28 de Mayo de 1999. Diario Oficial 43.601. [Por el cual se modifica el Decreto 692 de 1995.]. Bogotá, D.C., Colombia. Presidencia de la República de Colombia. (2000). Decreto 1382 del 12 de Julio de 2000. Diario Oficial 44.082. [Por el cual establecen reglas para el reparto de la acción de tutela.]. Bogotá, D.C., Colombia.

Presidencia de la República de Colombia. (2003). Decreto 190 del 30 de Enero de 2003. Diario Oficial 45.081. [Por el cual se reglamenta parcialmente la Ley 790 de 2002.]. Bogotá, D.C., Colombia.

Presidencia de la República de Colombia. (2005). Decreto 1227 del 21 de Abril de 2005. Diario Oficial 45890. [Por el cual se reglamenta parcialmente la Ley 909 de 2004 y el Decretoley 1567 de 1998.]. Bogotá, D.C., Colombia.

Presidencia de la República de Colombia. (2005). Decreto 2539 del 22 de Julio de 2005. Diario Oficial 45980. [Por el cual se establecen las competencias laborales generales para los empleos públicos de los distintos niveles jerárquicos de las entidades a las cuales se aplican...]. Bogotá, D.C., Colombia. 
Presidencia de la República de Colombia. (2014). Decreto 1507 del 12 de Agosto de 2014. [Por el cual se expide el Manual Único para la Calificación de la Pérdida de la Capacidad Laboral y Ocupacional.]. Bogota, D.C., Colombia.

Presidencia de la República de Colombia. (2014). Decreto- Ley 20 del 9 de Enero de 2014. Diario Oficial 49.028. [Por el cual se clasifican los empleos y se expide el régimen de carrera especial de la Fiscalía General de la Nación y de sus entidades adscritas.]. Bogotá, D.C., Colombia.

Presidente de la República de Colombia. (2005). Decreto 1601 del 20 de Mayo de 2005. [Por el cual se establece la evaluación de competencias gerencia les para la provisión de empleos de libre nombramiento y remoción.]. Bogotá, D.C., Colombia.

Comisión Interamericana de Derechos Humanos (2007). El acceso a la justicia como garantía de los derechos económicos, sociales y culturales. Estudio de estándares fijados por el sistema interamericano de derechos humanos (OEA). Estados Unidos.

Vásquez, J. (2009). Supresión de cargos público e incorporación de empleados a la nueva planta de personal. El derecho a la igualdad y la diferenciación positiva. Bogotá D.C Universidad Externado de Colombia.

Quintero, D. (2014). La meritocracia en Colombia frente al nombramiento en provisionalidad. Tunja.: Universidad Santo Tomás.

Caicedo, M. (2014). La provisionalidad dentro del marco de la carrera administrativa. Antioquia: Universidad de Antioquia.

Torres, J y Ruiz O, La estabilidad reforzada de los empleados en provisionalidad” Bogotá D.C Universidad Libre de Colombia.

Ramirez, J. (2011). Bogotá: La carrera administrativa en Colombia - análisis y perspectivas. Bogotá, D.C.: Universidad Nacional de Colombia. 
Haydée, Et (2000). Ley, mercado y discriminación el género del trabajo (CEADEL-Biblos, BsAS; Argentina 2000.

Puentes, G. (2004). La Carrera Administrativa: ¿anhelo o realidad? Desafíos. (11), 60-105.

Rodríguez, L. (2008). Derecho administrativo general y colombiano. Bogotá, D.C.: Temis.

Valdés, G (2009). Reflexiones sobre derecho laboral en el siglo XXI (EUR) Bogotá DC 2009.

Valdés, E. (2009) La provisionalidad y la facultad discrecional de la administración en el ordenamiento jurídico colombiano. Medellin 2009.

Montezuma, S. (2016) La justicia y su poder, los (as) jueces (as) y sus palabras. Estudio de género desde la región. Universidad Nacional Bogotá D.C 2017.

Senado de la República de Colombia. (2010). Proyecto de ley 54 de 2010 Senado y 170 de 2010 Cámara. [Por la cual se implementa el Retén Social, que garantiza la estabilidad laboral a grupos vulnerables y se dictan otras disposiciones.]. Bogotá, D.C., Colombia.

Sistema de Naciones Unidas de Panamá. (2010). Convención sobre la eliminación de todas las formas de discriminación contra la mujer (CEDAW). Panamá: Unicef.

Tribunal Administrativo de Cundinamarca. (2011). Sentencia nº 2006-00134, sección segunda del 7 de Abril de 2011. Bogotá D.C., Colombia.

Tribunal Constitucional de España. (2000). Sentencia 186 del 10 de Septiembre de 2000. BOE núm. 192. Sala Cuarta del Tribunal Supremo. M.P.: don Fernando Garrido Falla . Madrid, España.

Tribunal Constitucional de España. (2000). STC 186/2000 del 10 de Julio de 2000. BOE no: 192. Madrid, España.

Vega, M. (2010). Derecho Procesal Administrativo, 3era Edición. Bogotá, D.C.: Leyer. 
Vicepresidencia de la República de Colombia. (1995). Conpes 2761 ["Política de prevención y atención a la discapacidad".]. Bogotá, D.C.: Conpes.

Vidal, J. (1994). Derecho administrativo. Bogotá, D.C.: Temis.

Villegas, J. (2011). Derecho administrativo laboral. Bogotá, D.C. : Edición librería Ibáñez.

Younes, D. (1994). Curso elemental de derecho administrativo. Bogotá, D.C.: Ediciones jurídicas Gustavo Ibáñez.

Younes, D. (2005). Derecho administrativo laboral. Bogotá, D.C: Temis s.a. 


\section{Sentencias}

Consejo de Estado. (2003). Sala de lo contencioso administrativo, Sección Segunda; Sentencia del 13 de Marzo de 2003. [Consejero Ponente: Tarsicio Cáceres Toro]. Radicación No. 76001-23-31-000-1998-1834-01. Bogotá D.C., Colombia.

Consejo de Estado. (2004). Sentencia del 5 de febrero de 2004. Radicación número: 25000-2325000-1999- 0403-01(105-02). Sala de lo Contencioso Administrativo Sección Segunda Subsección "B". M.P.: Tarsicio Cáceres Toro. Bogotá, D.C., Colombia.

Consejo de Estado. (2005). Sala de lo contencioso administrativo, Sección Segunda- Sub Sección "A" del 30 de junio de 2005. [Consejera Ponente: Dra: Ana Margarita Olaya Forero]. Radicación No. 760012331000200101469-01(3211-04). Bogotá D.C., Colombia.

Consejo de Estado. (2005). Sentencia del 30 de junio de 2005. Radicación No.

760012331000200101469-01(3211-04). Sala de lo Contencioso Administrativo Sección Segunda - Sub Sección "A". M.P.: Ana Margarita Olaya Forero. Bogotá D.C., Colombia. Consejo de Estado. (2007). Sala de lo contencioso administrativo, Sección Segunda - Subsección "A" del 14 de junio de 2007. [Consejera ponente: Ana Margarita Olaya Forero]. Radicación número: 08001-23-31-000-2004-02778-01(0973-06). Bogotá, D.C., Colombia.

Consejo de Estado. (2010). Sala de lo contencioso administrativo, Sección Segunda, Sentencia del 10 de noviembre de 2010. [M.P. Gustavo Eduardo Gómez Aranguren] Radicación no. 0568-08. Bogotá, D.C., Colombia.

Consejo de Estado. (2011). Sentencia no 27001233100020040048601, Sección Segunda del 30 de Marzo de 2011. . Bogotá D.C., Colombia. 
Consejo de Estado (2012) Sala de lo contencioso administrativo, Sección segunda, Subsección A, Radicación 25000-23-25-000-2001-09480-01(2378-08) [Consejero ponente: Alfonso Vargas Rincón.]

Consejo de Estado. (2015). Sentencia n 47001-23-31-000-2011-00006-02, Sección Cuarta del 26 de Febrero de 2015. Bogotá, D.C., Colombia.

Consejo Nacional de Política Económica y Social. (2011). Documento Conpes Social 140 [Modificación al documento Conpes Social 91 del 14 de marzo de 2005 “Metas y Estrategias de Colombia para el logro de los Objetivos de Desarrollo del Milenio- 2015”]. Bogotá D.C.: Conpes.

Consejo de Estado . (2006). Sala de lo Contecioso Administrativo Sección Segunda Subsección "B" Sentencia del 23 de febrero de 2006. [Consejero Ponente: Tarsicio Cáceres] Radicación No. 7600123-3100020010066301. Bogotá, D.C., Colombia.

Corte Constitucional de la Repúbica de Colombia. (1998). Sentencia C-563 del 7 de octubre de 1998 [Magistrados Ponentes: Antonio Barrera; Carlos Gaviria]. Bogotá, D.C., Colombia. Corte Constitucional de la República Colombia. (2005). Sentencia T-846 del 16 de Agosto de 2005. Sala Quinta de Revisión de la Corte Constitucional. M.P.: Rodrigo Escobar Gil. Bogotá, D. C., Colombia.

Corte Constitucional de la República de Colombia. (1992). Sentencia T-403 del 3 de Junio de 1992. Sala Segunda de Revisión. M.P.: Alejandro Martinez Caballero. Bogotá, D.C., Colombia.

Corte Constitucional de la República de Colombia. (1992). Sentencia T-412 del 17 de Junio de 1992. Sala Cuarta de Revisión de la Corte Constitucional. M.P.: Alejandro Martinez Caballero. Bogotá, D.C., Colombia. 
Corte Constitucional de la República de Colombia. (1992). Sentencia T 415 del 17 de Junio de 1992. Sala Primera de Revisión. M.P.: Jose Gregorio Hernandez Galindo. Bogotá, D.C., Colombia.

Corte Constitucional de la República de Colombia. (1993). Sentencia C-074 del 25 de Febrero de 1993. Sala Plena de lo Contensioso Administrativo. M.P.: Ciro Angarita Baron. Bogotá, D.C., Colombia.

Corte Constitucional de la República de Colombia. (1993). Sentencia T-081 del 26 de Febrero de 1993. Sala Segunda de Revisión. M.P.: Alejandro Martinez Caballero; Jose Gregorio Hernandez Galindo. Bogotá, D.C., Colombia.

Corte Constitucional de la República de Colombia. (1993). Sentencia T-329 del 12 de Agosto de 1993. Sala Tercera de Revisión. M.P.: Jose Gregorio Hernandez Galindo. Bogotá, D.C., Colombia.

Corte Constitucional de la República de Colombia. (1994). Sentencia C-195 del 21 de Abril de 1994. Sala Plena de la Corte Constitucional. M.P.: Vladimiro Naranjo Mesa. Bogotá, D.C., Colombia.

Corte Constitucional de la República de Colombia. (1995). Sentencia C-069 del 23 de febrero de 1995. Sala de la Corte Constitucional. M.P.: Hernando Herrera Vergara. Bogotá D.C., Colombia.

Corte Constitucional de la República de Colombia. (1996). Sentencia C-126 del 27 de Marzo de 1996. Sala Plena de la Corte Constitucional. M.P.: Fabio Moron Díaz. Bogotá, D.C., Colombia. 
Corte Constitucional de la República de Colombia. (1997). Sentencia T-270 del 29 de Mayo de 1997 . Sala Séptima de Revisión de la Corte Constitucional. M.P.: Alejandro Martínez. Caballero. Bogotá, D.C., Colombia.

Corte Constitucional de la República de Colombia. (1997). Sentencia T-662 del 9 de diciembre de 1997. Sala Sexta de Revisión de la Corte Constitucional. M.P.: Alejandro Martínez Caballero. Bogotá D.C., Colombia.

Corte Constitucional de la República de Colombia. (1998). Sentencia C-339 del 8 de Julio de 1998. Sala Plena de la Corte Constitucional. M.P.: Carlos Gaviria Díaz. Bogotá, D.C., Colombia.

Corte Constitucional de la República de Colombia. (1998). Sentencia SU-250 del 26 de mayo de 1998. Sala Plena de la Corte Constitucional. M.P.: Alejandro Martinez Caballero. Bogotá, D.C., Colombia.

Corte Constitucional de la República de Colombia. (1998). Sentencia T-800 del 14 de Diciembre de 1998. Sala Novena de Revisión de la Corte Constitucional. M.P.: Vladimiro Naranjo Mesa. Bogotá, D.C., Colombia.

Corte Constitucional de la República de Colombia. (2000). Sentencia C-371 del 29 de Marzo de 2000. Sala Plena de la Corte Constitucional. M.P.: Carlos Gaviria Díaz. Bogotá, D. C., Colombia.

Corte Constitucional de la República de Colombia. (2000). Sentencia C-483 del 4 de Mayo de 2000. Sala Plena de la Corte Constitucional. M.P.: José Gregorio Hernández Galindo. 
Bogotá, D.C., Colombia.

Corte Constitucional de la República de Colombia. (2000). Sentencia C 486 del 4 de Mayo de 2000. Sala Plena de la Corte Constitucional. M.P.: José Gregorio Hernández Galindo. Bogotá, D.C., Colombia.

Corte Constitucional de la República de Colombia. (2000). Sentencia C-563 del 17 de Mayo de 2000. Sala Plena de la Corte Constitucional. M.P.: Fabio Moron Díaz. Bogotá, D.C., Colombia.

Corte Constitucional de la República de Colombia. (2000). Sentencia C-734 del 21 de Junio de 2000. Sala Plena de la Corte Constitucional. M.P.: Vladimiro Naranjo Mesa. Bogotá, D.C., Colombia.

Corte Constitucional de la República de Colombia. (2001). Sentencia T-343 del 29 de Marzo de 2001. Sala Quinta de Revisión de la Corte Constitucional. M.P.: Rodrigo Escobar Gil. Bogotá, D.C., Colombia.

Corte Constitucional de la República de Colombia. (2002). Sentencia T-884 del 17 de Octubre de 2002. Sala Novena de Revisión de Tutelas de la Corte Constitucional. M.P.: Clara Inés Vargas Hernández. Bogotá, D. C., Colombia.

Corte Constitucional de la República de Colombia. (2003). Sentencia C-1039 del 5 de Noviembre de 2003. Sala Plena de la Corte Constitucional. M.P.: Alfredo Beltrán Sierra . Bogotá, D.C., Colombia.

Corte Constitucional de la República de Colombia. (2003). Sentencia C-184 del 4 de Marzo de 2003. Sala Plena de la Corte Constitucional. M.P.: Manuel José Cepeda Espinosa. 
Bogotá, D.C., Colombia.

Corte Constitucional de la República de Colombia. (2003). Sentencia C-837 del 23 de

Septiembre de 2003. Sala Plena de la Corte Constitucional. M.P.: Alfredo Beltrán Sierra.

Bogotá, D. C., Colombia.

Corte Constitucional de la República de Colombia. (2003). Sentencia C-964 del 21 de Octubre de 2003. Sala Plena de la Corte Constitucional. M.P.: Alvaro Tafur Galvis. Bogotá D. C., Colombia.

Corte Constitucional de la República de Colombia. (2003). Sentencia T-519 del 26 de Junio de 2003. Sala Sexta de la Corte Constitucional. M.P.: Marco Gerardo Monroy Cabra. Bogotá D.C., Colombia.

Corte Constitucional de la República de Colombia. (2003). Sentencia T-610 del 24 de Julio de 2003. Sala Segunda de Revisión de la Corte Constitucional. M.P.: Alfredo Beltrán Sierra. Bogotá D.C., Colombia.

Corte Constitucional de la República de Colombia. (2003). Sentencia T-610 del 24 de Julio de 2003. Sala Segunda de Revisión de la Corte Constitucional. M.P.: Alfredo Beltrán Sierra. Bogotá, D.C., Colombia.

Corte Constitucional de la República de Colombia. (2004). Sentencia C-044 del 27 de Enero de 2004. Sala Plena de la Corte Constitucional. M.P.: Jaime Araujo Renteria. Bogotá, D. C., Colombia. 
Corte Constitucional de la República de Colombia. (2004). Sentencia C-1128 del 9 de noviembre de 2004. Sala Plena de la Corte Constitucional. M.P.: Alfredo Beltrán Sierra. Bogotá, D. C., Colombia.

Corte Constitucional de la República de Colombia. (2004). Sentencia C 722 del 3 de Agosto de 2004. Sala Plena de la Corte Constitucional. M.P.: Rodrigo Escobar Gil. Bogotá, D.C., Colombia.

Corte Constitucional de la República de Colombia. (2004). Sentencia C-722 del 3 de Agosto de 2004. Sala Plena de la Corte Constitucional. M.P.: Rodrigo Escobar Gil. Bogotá, D.C, Colombia.

Corte Constitucional de la República de Colombia. (2004). Sentencia T-1190 del 25 de Noviembre de 2004. Sala Sexta de Revisión de tutelas de la Corte Constitucional. M.P.: Marco Gerardo Monroy Cabra. Bogota D.C., Colombia.

Corte Constitucional de la República de Colombia. (2004). Sentencia T-521 del 20 de Mayo de 2004. Sala Cuarta de Revisión de la Corte Constitucional. M.P.: Jaime Córdoba Triviño. Bogotá D.C., Colombia.

Corte Constitucional de la República de Colombia. (2004). Sentencia T-876 del 9 de Septiembre de 2004. Sala Segunda Revisión de la Corte Constitucional. M.P.: Alfredo Beltrán Sierra. Bogotá, D.C., Colombia.

Corte Constitucional de la República de Colombia. (2005). Sentencia C-1189 del 22 de Noviembre de 2005. Sala Plena de la Corte Constitucional. M.P.: Humberto Antonio Sierra Porto. Bogotá, D. C., Colombia. 
Corte Constitucional de la República de Colombia. (2005). Sentencia C-733 del 14 de Julio de 2005. Sala Plena de la Corte ConstitucionaL. M.P.: Clara Inés Vargas Hernández. Bogotá, D. C., Colombia. 
Corte Constitucional de la República de Colombia. (2005). Sentencia SU 388 del 13 de Abril de 2005. Sala Plena de la Corte Constitucional. M.P.: Clara Inés Vargas Hernández. Bogotá, D.C., Colombia.

Corte Constitucional de la República de Colombia. (2005). Sentencia T-054 del 28 de Enero de 2005. Sala Cuarta de Revisión de la Corte Constitucional. M.P.: Jaime Córdoba Triviño. Bogotá, D.C., Colombia.

Corte Constitucional de la República de Colombia. (2005). Sentencia T-1159 del 17 de Noviembre de 2005. Sala Sexta de la Corte Constitucional. M.P.: Marco Gerardo Monroy Cabra. Bogotá D. C., Colombia.

Corte Constitucional de la República de Colombia. (2005). Sentencia T-1258 del 5 de Diciembre de 2005. Sala Octava de Revisión de la Corte Constitucional. M.P.: Alvaro Tafur Galvis. Bogotá, D. C., Colombia.

Corte Constitucional de la República de Colombia. (2005). Sentencia T-161 del 24 de Febrero de 2005. Sala Sexta de Revisión de tutelas de la Corte Constitucional. M.P.: Marco Gerardo Monroy Cabra. Bogotá D.C., Colombia.

Corte Constitucional de la República de Colombia. (2005). Sentencia T-399 del 14 de Abril de 2005. Sala Séptima de Revisión de Tutelas de la Corte Constitucional. M.P.: Jorge Ignacio Pretelt Chaljub. Bogotá, D. C., Colombia.

Corte Constitucional de la República de Colombia. (2005). Sentencia T-530 del 20 de Mayo de 2005. Sala Tercera de Revisión de la Corte Constitucional. M.P.: Manuel José Cepeda 
Espinosa. Bogotá, D.C., Colombia.

Corte Constitucional de la República de Colombia. (2005). Sentencia T 752 del 14 de Julio de 2005. Sala Primera de Revisión de la Corte Constitucional. M.P.: Jaime Araújo Rentería. Bogotá, D.C., Colombia.

Corte Constitucional de la República de Colombia. (2005). Sentencia T-768 del 25 de Julio de 2005. Sala Primera de Revisión de la Corte Constitucional. M.P.: Jaime Araújo Rentería. Bogotá, D. C., Colombia.

Corte Constitucional de la República de Colombia. (2005). Sentencia T-834 del 12 de Agosto de 2005. Sala Novena de Revisión de la Corte Constitucional. M.P.: Clara Inés Vargas Hernández. Bogotá D.C., Colombia.

Corte Constitucional de la República de Colombia. (2006). Sentencia C-049 del 1 de Febrero de 2006. Sala Plena de la Corte Constitucional. M.P.: Jaime Araújo Rentería. Bogotá, D. C., Colombia.

Corte Constitucional de la República de Colombia. (2006). Sentencia C-989 del 29 de Noviembre de 2006. Sala Plena de la Corte Constitucional. M.P.: Álvaro Tafur Galvis. Bogotá, D.C., Colombia.

Corte Constitucional de la República de Colombia. (2006). Sentencia T-1050 del 7 de Diciembre de 2006. Sala Primera de Revisión de la Corte Constitucional. M.P.: Jaime Araújo Rentería. Bogotá, D. C., Colombia.

Corte Constitucional de la República de Colombia. (2006). Sentencia T-231 del 27 de Marzo de 
2006. Sala Quinta de Revisión de la Corte Constitucional. M.P.: Rodrigo Escobar Gil. Bogotá, D.C., Colombia.

Corte Constitucional de la República de Colombia. (2006). Sentencia T 257 del 30 de Marzo de 2006. Sala Tercera de la Corte Constitucional. M.P.: Manuel Jose Cepeda Espinosa. Bogotá, D.C., Colombia.

Corte Constitucional de la República de Colombia. (2006). Sentencia T-303 del 18 de Abril de 2006. Sala Quinta de Revisión de la Corte Constitucional. M.P.: Rodrigo Escobar Gil. Bogotá, D.C., Colombia.

Corte Constitucional de la República de Colombia. (2006). Sentencia T-432 del 1 de junio de 2006. Sala Segunda de Revisión de la Corte Constitucional. M.P.: Alfredo Beltrán Sierra. Bogotá, D.C., Colombia.

Corte Constitucional de la República de Colombia. (2006). Sentencia T-556 del 18 de julio de 2006. Sala Séptima de Revisión de la Corte Constitucional. M.P.: Humberto Antonio Sierra Porto. Bogotá, D.C., Colombia.

Corte Constitucional de la República de Colombia. (2006). Sentencia T-592 del 27 de Julio de 2006. Sala Primera de Revisión de la Corte Constitucional. M.P.: Jaime Araújo Rentería. Bogotá, D.C., Colombia.

Corte Constitucional de la República de Colombia. (2006). Sentencia T-593 del 27 de Julio de 2006. Sala Novena de Revisión de la Corte Constitucional. M.P.: Clara Ines Vargas Hernandez. Bogotá, D. C., Colombia.

Corte Constitucional de la República de Colombia. (2006). Sentencia T-626 del 3 de Agosto de 
2006. Sala Octava de Revisión de la Corte Constitucional. M.P.: Alvaro Tafur Galvis.

Bogotá, D. C., Colombia.

Corte Constitucional de la República de Colombia. (2007). Sentencia C 279 del 18 de abril de

2007. Sala Plena de la Corte Constitucional. M.P.: Manuel José Cepeda Espinosa. Bogotá D.C., Colombia.

Corte Constitucional de la República de Colombia. (2007). Sentencia T-837 del 11 de Octubre de 2007. Sala Novena de Revisión de la Corte Constitucional. M.P.: Clara Inés Vargas Hernández. Bogotá, D.C., Colombia.

Corte Constitucional de la República de Colombia. (2008). Sentencia T-1211 del 5 de Diciembre de 2008. Sala Novena de Revisión de la Corte Constitucional. M.P.: Clara Inés Vargas Hernández. Bogotá, D.C., Colombia.

Corte Constitucional de la República de Colombia. (2008). Sentencia T-254 del 10 de Marzo de 2008. Sala Octava de Revisión de la Corte Constitucional. M.P.: Humberto Antonio Sierra Porto. Bogotá D.C., Colombia.

Corte Constitucional de la República de Colombia. (2008). Sentencia T-453 del 9 de Mayo de 2008. Sala Segunda de Revisión de la Corte Constitucional. M.P.: Manuel José Cepeda Espinosa. Bogotá, D.C., Colombia.

Corte Constitucional de la República de Colombia. (2008). Sentencia T-587 del 12 de Junio de 2008. Sala Octava de Revisión de la Corte Constitucional. M.P.: Humberto Antonio Sierra Porto. Bogotá D.C., Colombia. 
Corte Constitucional de la República de Colombia. (2008). Sentencia T-587 del 12 Junio de 2008. Sala Octava de Revisión de la Corte Constitucional. M.P.: Humberto Antonio Sierra Porto. Bogotá D.C., Colombia. 
Corte Constitucional de la República de Colombia. (2009). Sentencia C-588 del 27 de Agosto de 2009. Sala Plena de la Corte Constitucional. M.P.: Gabriel Eduardo Mendoza Martelo. Bogotá D.C., Colombia.

Corte Constitucional de la República de Colombia. (2009). Sentencia T-833 del 20 de Noviembre de 2009. Sala Segunda de Revisión de la Corte Constitucional. M.P.: María Victoria Calle Correa. Bogotá, D.C., Colombia.

Corte Constitucional de la República de Colombia. (2010 ). Proyecto de Ley 054 del 28 de Septiembre de 2010 de Senado. [Por medio del cual se implementa el Retén Social, que garantiza la estabilidad laboral a los grupos vulnerables y se dictan otras disposiciones]. Bogotá, D.C., Colombia.

Corte Constitucional de la República de Colombia. (2010). Sentencia C-431 del 2 de Junio de 2010. Sala Plena de la Corte Constitucional. M.P.: Luis Ernesto Vargas Silva. Bogotá D.C., Colombia.

Corte Constitucional de la República de Colombia. (2010). Sentencia C-553 del 6 de julio de 2010. Sala Plena de la Corte Constitucional. M.P.: Luis Ernesto Vargas Silva. Bogotá D.C., Colombia.

Corte Constitucional de la República de Colombia. (2010). Sentencia SU-917 del 16 de Noviembre de 2010. Sala Plena de la Corte Constitucional. M.P.: Jorge Iván Palacio Palacio. Bogotá, D.C, Colombia.

Corte Constitucional de la República de Colombia. (2010). Sentencia T-039 del 20 de Noviembre de 2010. Sala Segunda de Revisión de la Corte Constitucional. M.P.: María 
Victoria Calle Correa. Bogotá, D.C., Colombia.

Corte Constitucional de la República de Colombia. (2011). Sentencia C 371 del 11 de Mayo de 2011. Sala Plena de la Corte Constitucional. M.P.: Luís Ernesto Vargas Silva. Bogotá, D.C., Colombia.

Corte Constitucional de la República de Colombia. (2011). Sentencia C-490 del 23 de Junio de 2011. Sala de lo Contencioso Administrativo. M.P.: Luis Ernesto Vargas Silva. Bogotá, D.C., Colombia.

Corte Constitucional de la República de Colombia. (2011). Sentencia SU-691 del 21 de Septiembre de 2011. Sala Plena de la Corte Constitucional. M.P.: Humberto Antonio Sierra Porto. Bogotá D.C., Colombia.

Corte Constitucional de la República de Colombia. (2011). Sentencia T-656 del 5 de septiembre de 2011. Sala Séptima de Revisión de Tutelas de la Corte Constitucional. M.P.: Jorge Ignacio Pretelt Chaljub. Bogotá D.C., Colombia.

Corte Constitucional de la República de Colombia. (2011). Sentencia T-961 del 16 de Diciembre de 2011. Sala Cuarta de Revisión de la Corte Constitucional. M.P.: Gabriel Eduardo Mendoza Martelo. Bogotá, D. C., Colombia.

Corte Constitucional de la República de Colombia. (2012). Sentencia C-243 del 22 de Marzo de 2012. Sala Plena de la Corte Constitucional. M.P.: Luis Ernesto Vargas Silva. Bogotá, D.C., Colombia.

Corte Constitucional de la República de Colombia. (2012). Sentencia SU-539 del 12 de Julio de 2012. Sala Plena de la Corte Constitucional. M.P.: Luis Ernesto Vargas Silva. Bogotá, D.C., Colombia. 
Corte Constitucional de la República de Colombia. (2012). Sentencia T-102 del 20 de Febrero de 2012. Sala Segunda de Revisión. M.P.: Mauricio González Cuervo. Bogotá, D.C., Colombia.

Corte Constitucional de la República de Colombia. (2012). Sentencia T-186/13 del 10 de Abril de 2012. Sala Novena de Revisión de la Corte Constitucional. M.P.: Luis Ernesto Vargas Silva. Bogotá, D.C., Colombia.

Corte Constitucional de la República de Colombia. (2012). Sentencia T-835 del 23 de Octubre de 2012. Sala Novena de Revisión de la Corte Constitucional. M.P.: Luis Ernesto Vargas Silva. Bogotá, D.C., Colombia.

Corte Constitucional de la República de Colombia. (2013). Sentencia T-604 del 30 de Agosto de 2013. Sala Plena de la Corte Constitucional. M.P.: Jorge Iván Palacio Palacio. Bogotá, D.C., Colombia.

Corte Constitucional de la República de Colombia. (2013). Sentencia T-803 del 12 de Noviembre de 2013. Sala Sexta de Revisión de la Corte Constitucional. M.P.: Nilson Pinilla Pinilla. Bogotá, D.C., Colombia.

Corte Constitucional de la República de Colombia. (2014). Sentencia C-288 del 20 de Mayo de 2014. Sala Plena de la Corte Constitucional. M.P.: Jorge Ignacio Pretelt Chaljub. Bogotá D. C., Colombia.

Corte Constitucional de la República de Colombia. (2014). Sentencia T-326 del 3 de junio de 2014. Sala Primera de Revisión de la Corte Constitucional. M.P.: María Victoria Calle Correa. Bogotá, D.C., Colombia.

Corte Constitucional de la República de Colombia. (2014). Sentencia T 400 del 26 de Junio de 
2014. Sala Quinta de Revisión de la Corte Constitucional. M.P.: Jorge Iván Palacio Palacio. Bogotá, D.C., Colombia.

Corte Constitucional de la República de Colombia. (2015). Sentencia T-345 del 5 de Junio de 2015. Sala Séptima de Revisión de tutelas de la Corte Constitucional. M.P.: Jorge Ignacio Pretelt Chaljub. Bogotá D.C., Colombia.

Corte Constitucional de la República de Colombia. (2016). Sentencia T-407 del 4 de Agosto de 2016. Sala Novena de Revisión de la Corte Constitucional. M.P.: Luis Ernesto Vargas Silva. Bogotá, D.C., Colombia. 